\title{
Selection of Manning's Roughness Coefficient for Natural and Constructed Vegetated and Non- Vegetated Channels, and Vegetation Maintenance Plan Guidelines for Vegetated Channels in Central Arizona
}

By Jeff V. Phillips and Saeid Tadayon

Prepared in cooperation with the

FLOOD CONTROL DISTRICT OF MARICOPA COUNTY

Scientic Investigations Report 2006-5108 


\section{U.S. Department of the Interior DIRK KEMPTHORNE, Secretary}

\section{U.S. Geological Survey \\ Mark Meyers, Director}

\section{U.S. Geological Survey, Reston, Virginia: 2007}

For product and ordering information:

World Wide Web: http://www.usgs.gov/pubprod

Telephone: 1-888-ASK-USGS

For more information on the USGS — the Federal source for science about the Earth, its natural and living resources, natural hazards, and the environment:

World Wide Web: http://www.usgs.gov

Telephone: 1-888-ASK-USGS

Any use of trade, product, or firm names is for descriptive purposes only and does not imply endorsement by the U.S. Government.

Although this report is in the public domain, permission must be secured from the individual copyright owners to reproduce any copyrighted materials contained within this report.

Suggested citation:

Phillips, J.V., and Tadayon, S., 2006, Selection of Manning's roughness coefficient for natural and constructed vegetated and non-vegetated channels, and vegetation maintenance plan guidelines for vegetated channels in central Arizona: U.S. Geological Survey Scientific Investigations Report 2006-5108, 41 p. 


\section{Contents}

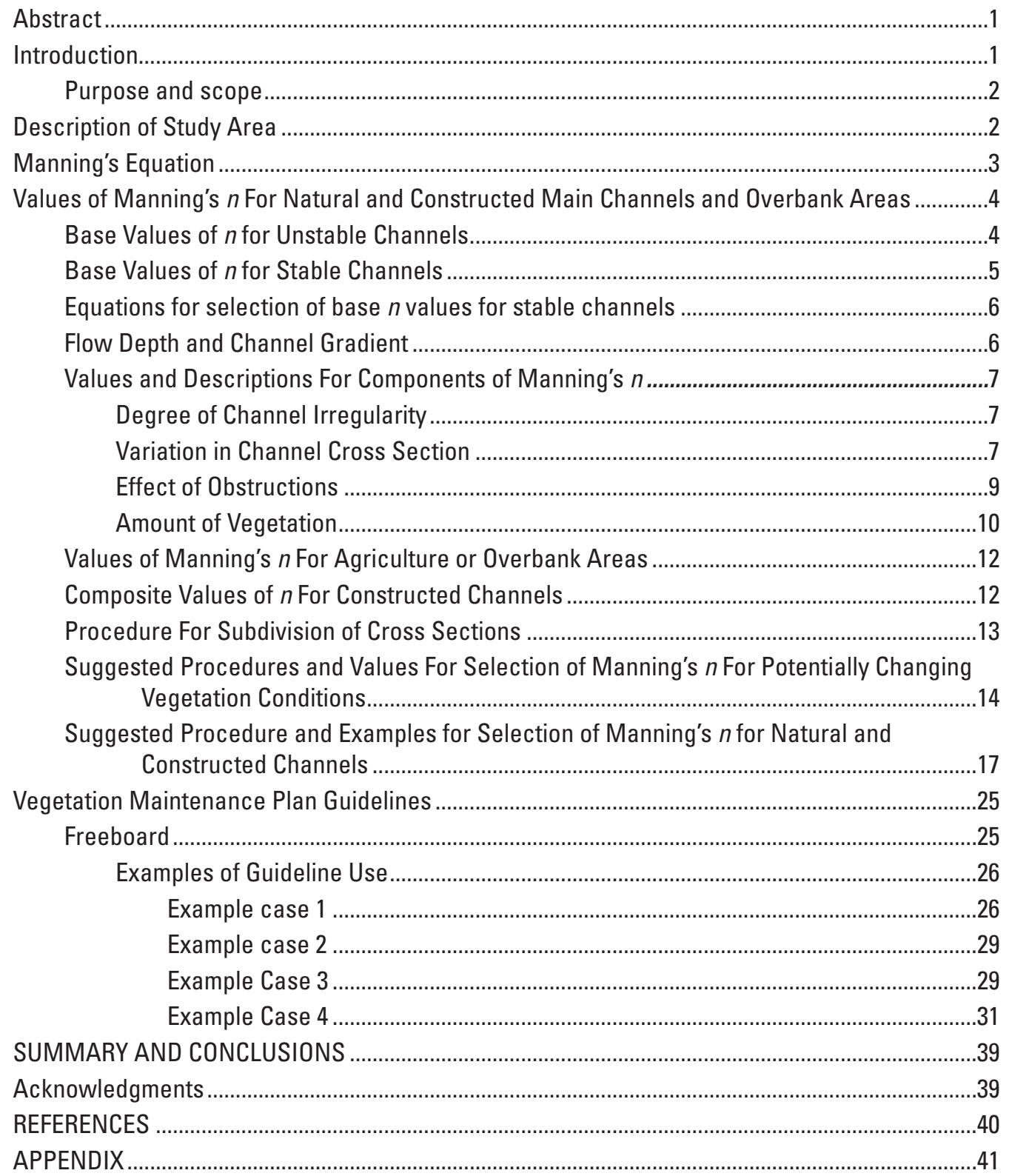




\section{Figures}

1. Map showing study area in Maricopa County, Arizona.

2. Relation of stream power and median grain size to flow regime. ...4

3. Idealized diagram of bed and surface configurations for alluvial streams for various regimes of flow.

4. Typical unstable sand channel in central Arizona. A, View upstream of midchannel during no-flow period. $B$, View from cableway looking upstream during flow of February 9, 1993.

5. Typical cobble-bed channel in central Arizona for which Manning's $n$ was verified; and used for development of equation 4.

6. Typical high-gradient cobble-bed channel in California for which Manning's $n$ was verified and utilized for development of equation 3.

7. The Manning $n$ component for channel bank is considered smooth with a corresponding component of 0.000 (table 3).

8. The Manning $n$ component for the eroded and scoured banks is considered moderate with a range of 0.006 to 0.010 (table 3).

9. The Manning $n$ component for the eroded and slightly scoured banks is considered minor with a range of 0.001 to 0.005 (table 3).

10. The Manning $n$ component for the sloughed banks; jagged and irregular surfaces is considered severe with a range of 0.011 to 0.020 (table 3).

11. Channel reach where the size and shape of sections change gradually. The Manning $n$ component for this example is considered negligible or 0.000 (table 3).....9

12. General flow disturbance caused by bridge piers at Colorado River near Moab, Utah. . .9

13. Large angular boulder in mid channel. 9

14. Power pole obstructing less than 5 percent of the channel area. The Manning's $n$ component for the obstruction is considered negligible, with a corresponding range in $n$ of 0.000 to 0.004 (table 3)......

15. Removed brush caught on more flow resistant vegetation resulting in a localized angular obstruction with a larger sphere of influence than the resistant vegetation alone

16. Bridge pier for which the Manning's $n$ component is considered to range from 0.005 to 0.015 (table 3).

17. Tall grass laid over as a result of a flow of 6,480 cubic feet per second........................10

18. Lone tree that is approximately 20 feet in height. ...........................................................10

19. Randomly scattered shrubs. Flow elevation approximated level of the survey rod for a discharge of 403 cubic feet per second.

20. Large mesquite with branches that hang over the main-channel area.........................11

21. Randomly distributed mesquite and palo verde approximately 15 to 20 feet in height (table 3)

22. Image showing flow altered by vegetation (table 3).

23. The Manning $n$ component for the vegetation is considered extremely large, with a corresponding range in $n$ of 0.100 to 0.200 (table 3). 


\section{Figures-Continued}

24. Extremely dense vegetation in the channel that drains this urban area.

A, Downstream from midchannel before the flow of December 10, 1991.

$B$, Upstream from left bank during the flow of December 10, 1991..............................11

25. Fields of $A$, Mature cotton in the summer and $B$, Defoliated cotton in the fall. ..............12

26. Manning's $n$-verification measurement made at a well-maintained construction channel (Phillips and Ingersoll, 1998). $A$, Channel survey made for verification of Manning's $n$. $B$, Channel conditions following flow..................................................13

27. Subdivision criteria commonly used for streams in Maricopa County, Arizona.............13

28. Effects of subdivision on a trapezoidal section. .....................................................14

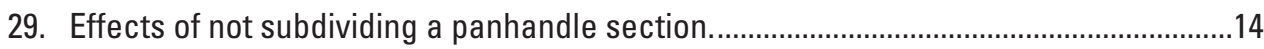

30. Impact of similar flows, or stream power, on different vegetation species of similar heights. $A$, Willow. $B$, Palo verde......................................................................

31. Vegetation aligned parallel to flow as a result of consistant base flow in a

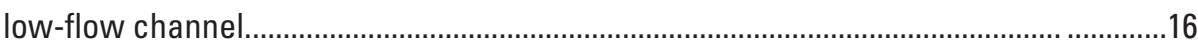

32. Vegetation that was affected little by flow................................................................16

33. Relationship between stream power and a vegetation-susceptibility index for estimating the effect of flow on vegetation conditions................................................17

34. Flow chart for assigning $n$ values (modified from Aldridge and Garrett, 1973). ..............18

35. Flow chart for estimating flow-induced changes to vegetation conditions. ...................19

36. Diagram of hypothetical channel showing reaches and segments used in assigning

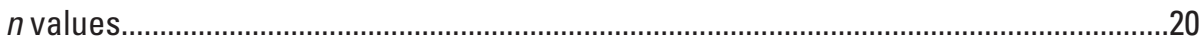

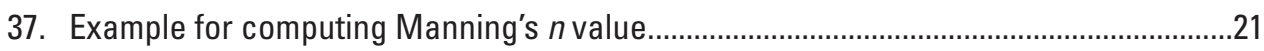

38. Diagram of hypothetical channel showing reaches used in assigning $n$ values.............22

39. Example for computing Manning's $n$ value.................................................................23

40. Impact of computed stream power on the vegetation-susceptibility index for

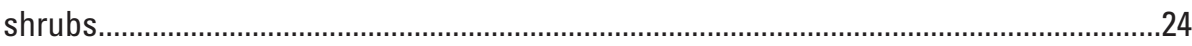

41. Constructed channel that required vegetation modification. $A$, Before maintenance of vegetation, July 28, 2005. B, After maintenance of vegetation, August $3,2005 \ldots \ldots . . .27$

42. Simulated water-surface elevations for the constructed channel in example case 1 . $A$, Initial channel conditions. $B$, Fully-grown vegetation conditions.

$C$, Post-vegetation maintenance conditions.

43. HECRAS standard-step computer simulations for the constructed channel in example case 2. $A$, Original design computed water-surface elevation for $n=0.045$ (base $n$ value $=0.030$ and future vegetation $n$-value component of 0.015 ).

$B$, Water-surface

44. Impact of computed stream power on the vegetation-susceptibility index for shrubs and mesquite.

45. Plan view illustration of constructed channel for example case 2, scenario 1 .............32

46. A constructed channel for example case 2 , scenario 1. A, Manning's composite roughness coefficient is estimated to be 0.150 prior to vegetation maintenance. $B$, Manning's composite roughness coefficient is estimated to be 0.040 subsequent to vegetation maintenance. $C$, Vegetation conditions approximately six months following maintenance. 


\section{Figures-Continued}

47. Plan view illustration of constructed channel for example case 2, scenario 2. Following vegetation maintenance, trees are clumped together primarily to provide better habitat for wildlife

48. A constructed channel for example case 2, scenario 2. A, Manning's composite roughness coefficient is estimated to be 0.150 prior to vegetation maintenance. $B$, Manning's composite roughness coefficient is estimated to be 0.045 subsequent to vegetation maintenance.

49. Example of a channel with randomly distributed shrubs prior to the statistical 25-year event.

50. Example of a channel with removed shrubs following the statistical 25 -year event.....34

51. Locations and density of palo verde trees in the channel for example case 3 following the 25-year flow event.

52. Base Flow Elevation (BFE) with 1 foot of freeboard for the channel used in example case 3 for a 100-year design flood.

53. Example of a channel with a vegetation density greater than 70 percent five years after a Flood Insurance Study.

54. Example channel with development and five years of vegetation growth.

$A$, Distribution of shrubs and trees in main channel and approximate location of homes. B, Shrubs (smaller circles) and palo verde (larger circles) and homes along channel.

55. Impact of computed stream power on the vegetation-susceptibility index for shrubs and palo verde.

56. Plan view and cross-section views showing distribution of mesquite in the main channel, as simulated water-surface elevation, and location of homes. $A$, Plan view after mesquite trees were initially planted. $B$, Cross-section view of simulated water-surface for the design discharge for initial conditions. $C$, Plan view showing mesquite trees after 10 years of growth. $D$, Cross-section view of simulated water-surface for the design discharge for vegetation conditions after 10 years of growth. $E$, Plan view showing remaining mesquite trees following vegetation maintenance. $F$, Cross-section view of simulated water-surface for the design discharge for post-maintenance conditions.

57. Impact of computed stream power on the vegetation-susceptibility index for mesquite trees. 


\section{Tables}

1. Base values of Manning's $n$ for upper-regime flows in sand channels. ..........................5

2. Base values of Manning's $n$ for channels considered stable.........................................6

3. Adjustment factors or component ranges for various channel conditions used

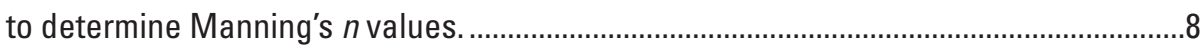

4. Values of Manning's $n$ for agriculture or overbank areas. .............................................12

5. Composite values of $n$ for stable-constructed channels. ................................................13

6. Regression equations relating bending moment to vegetation height for mesquite,

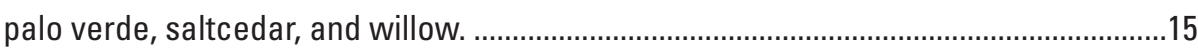

7. Vegetation-blocking coefficients for selected areas of flow blocked by vegetation.....16

8. Vegetation-distribution coefficients for vegetation oriented to flow.............................16

9. Flow-depth coefficients for ratios of hydraulic radius to average vegetation height....17

10. Vegetation characteristics, coefficients, and vegetation susceptibility index

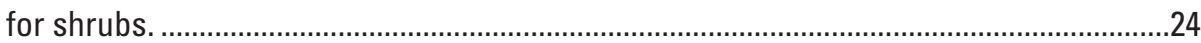

11. Hydraulic parameters used to compute stream power................................................24

12. Hydraulic properties of flow for the constructed channel in example case 1. Velocity, area, and water-surface elevations were computed by using estimated Manning's $n$ values and a design discharge.

13. Vegetation characteristics, coefficients, and vegetation-susceptibility index for shrubs and mesquite for example case 2 ...................................................................30

14. Hydraulic parameters used to compute stream power for example case 2..................30

15. Vegetation characteristics, coefficients, and vegetation-susceptibility index for shrubs and palo verde for example case 3. ..................................................................

16. Hydraulic parameters used to compute stream power for example case $3 . . . \ldots \ldots \ldots \ldots \ldots . . . .36$

17. Vegetation characteristics, coefficients, and vegetation-susceptibility index for

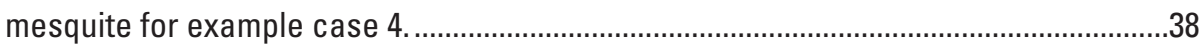

18. Hydraulic parameters used to compute stream power for example case 4 . ..................38

\section{Conversion Factors and Datums}

\begin{tabular}{lcl}
\hline \multicolumn{1}{c}{ Multiply } & By & \multicolumn{1}{c}{ To obtain } \\
\hline & Length & \\
inch (in.) & 25.4 & millimeter $(\mathrm{mm})$ \\
foot $(\mathrm{ft})$ & 0.3048 & meter $(\mathrm{m})$ \\
mile $(\mathrm{mi})$ & 1.609 & kilometer $(\mathrm{km})$ \\
\hline & Area & \\
\hline square mile $\left(\mathrm{mi}^{2}\right)$ & 2.590 & Square kilometer $\left(\mathrm{km}^{2}\right)$ \\
\hline & Flow rate & \\
\hline cubic foot per second $\left(\mathrm{ft}^{3} / \mathrm{s}\right)$ & 0.02832 & cubic meter per second $\left(\mathrm{m}^{3} / \mathrm{s}\right)$ \\
\hline
\end{tabular}


Leave this page blank 


\title{
Selection of Manning's Roughness Coefficient for Natural and Constructed Vegetated and Non-Vegetated Channels, and Vegetation Maintenance Plan Guidelines for Vegetated Channels in Central Arizona
}

\author{
By Jeff V. Phillips and Saeid Tadayon
}

\section{Abstract}

This report describes and presents the results of a study by the U.S. Geological Survey, done in cooperation with the Flood Control District of Maricopa County, to (1) describe procedures used in selection of Manning's coefficient, $n$, for stream channels located in semi-arid to arid environments, (2) describe a method for determining impact of flow on channel-vegetation conditions, and (3) describe and evaluate a new method for management of vegetation in stream channels. Verified and estimated $n$ values for natural and constructed stream channels in Arizona have been presented in several published documents. Much of this information is in the form of guidelines, tables, figures, and examples. This information has been compiled into this comprehensive document to be used as a guideline and tool for estimating $n$ values for hydraulic computation of flow in open channels.

Proper estimation of $n$ values for vegetated channels in arid to semi-arid environments can present difficulties in estimating the channel's resistance to flow. For example, vegetation in ephemeral and intermittent streams may change considerably over a period of time or during a flood event. Because vegetation can be a constantly changing factor, estimating $n$ values for the vegetation component can be difficult. Semi-empirical relations and guidelines developed to estimate impact of flow on channel-vegetation conditions are presented.

Developed engineering-based guidelines presented herein are intended to aid in optimizing the preservation of a riparian habitat and aesthetics of multi-use areas, while mitigating damage from floodflows along natural and constructed channels. The guidelines primarily are based on the vegetation component of $n$ values that should be maintained in a waterway to allow adequate freeboard, which is an additional amount of conveyance area intended to mitigate risk by providing a factor of safety. Vegetation maintenance plan guidelines are presented, including example cases that illustrate their use.

\section{Introduction}

The U.S. Geological Survey, in cooperation with the Flood Control District of Maricopa County, has been studying the hydraulic effects associated with channel-roughness elements in streams in Arizona. Computation of flow in an open channel requires evaluation of the channel's resistance to flow, which is typically represented by a roughness parameter, such as Manning's $n$. The characteristics of natural channels and of some constructed channels and the factors that affect channel roughness can vary greatly; however, the combinations of these factors are numerous. In many cases, components of Manning's $n$ cannot be determined with sufficient accuracy by direct measurement of roughness characteristics, such as vegetation and variations in channel shape. Therefore, selection of roughness for natural and constructed channels typically is based on field judgment and skill, which are acquired mainly through experience. The expertise necessary for proper selection of roughness coefficients can be obtained, in part, by examining characteristics of channels that have known or verified coefficients (Barnes, 1967; Aldridge and Garrett, 1973; Phillips and Ingersoll, 1998), or have been selected by experienced personnel (Thomsen and Hjalmarson, 1991). The roughness coefficient can be verified by computations made by using data from streamflow measurements and from measurements of the physical features of the channel. Photographs of channel segments for which $n$ values have been verified can be used as a comparison standard to aid in assigning $n$ values to similar channels. Semi-empirical equations that relate hydraulic and channel properties have been derived from verified values of Manning's $n$. The equations also can be used as a tool for selection of $n$ values.

In the arid to semi-arid southwestern United States, one factor that retards flow and that can have the greatest single impact on energy losses and resulting computed water-surface elevations is the vegetation occupying the channel bed, banks, and overflow areas. Vegetation characteristics for particular channel reaches may have a larger effect than all other flow 
resistance elements by a factor of three to four (Phillips and Ingersoll, 1998). Vegetation is a constantly changing factor as well; it can be laid over or removed during floodflows, or grow to substantial spatial densities and heights in just a few years' time. Different species of vegetation also have different flexural strengths for a given size or height, which further complicates assessing flow impacts on vegetation, and the subsequent impact of vegetation on flow-energy losses. When vegetation for a particular channel either grows to significant heights and densities or is laid over and possibly removed during floodflows, the roughness coefficients selected for that channel for earlier hydraulic studies, years, or decades may have changed significantly, possibly significantly impacting the earlier computed conveyance and water-surface elevations for the design discharge. A semi-empirical relation has been developed that relates hydraulic properties of flow to vegetation characteristics and conditions within the channel (Phillips and others, 1998). The relation will allow the user to determine impact of flow on the vegetation so estimates of $n$ values for the vegetation component can be more accurately selected. The relation is restricted primarily to vegetation growing in the main channel of natural and constructed stream channels.

In past decades, these heavy growths of vegetation may have been modified or removed completely to allow for adequate conveyance of floodflows. With a shift in emphasis in recent years toward preserving riparian vegetation to provide habitat for many species of wildlife and aesthetically pleasing multi-use areas for homeowners and businesses, however, engineering-based vegetation maintenance guidelines are now deemed to be necessary. Vegetation maintenance guidelines presented in this document are intended to optimize the preservation of riparian habitat and the aesthetics of multi-use areas, while mitigating damage from floodflows along natural and constructed channels.

\section{Purpose and scope}

Limerinos (1970) stated that it is unlikely the determination of $n$ values for channels will ever be an exact science; and Barnes (1967) indicated the selection of $n$ values remains chiefly an art primarily developed through experience.

According to Chow (1959), veterans at selecting $n$ values should exercise sound engineering judgment and experience; for a beginner, selection of $n$ values can be no more than a guess, and different individuals will obtain different results. The methods and guidelines herein, therefore, are intended to be an aid for development of experience necessary to negate gross errors in the selection of $n$ values for open-channel flow hydraulic computations. These guidelines also are intended to be a tool for (1) selection of roughness coefficients by veteran engineers and hydrologists, (2) assessment of flow on vegetation conditions, and (3) evaluation of vegetation conditions in constructed channels to determine the potential need for vegetation maintenance.

Engineering based vegetation assessment and maintenance guidelines are necessary to optimize preservation of riparian habitat and aesthetic value of multi-use areas, while ensuring channel conveyance is adequate to mitigate flood damage. The compilation of information from past publications into a new comprehensive manual, as well as newly developed vegetation-maintenance plan guidelines, can provide a substantive mechanism by which private sector managers and engineers; and local, state, and federal officials, as well as the public, can acquire better estimates of $n$ values for open-channel flow computations in central Arizona, as well as similar arid to semi-arid regions of the United States and the world.

\section{Description of Study Area}

The basin and range topography typical in most parts of Arizona is characterized by steep block-faulted mountains separated by gently sloping valleys. Ephemeral and intermittent streams in the study area (fig. 1) cover a wide variety of conditions ranging from unstable alluvial channels, generally stable channels of cobble to boulder-sized bed material, and extremely stable bedrock channels. Sand-dominated streambeds commonly are characterized by unstable boundary conditions, high sediment loads, and long periods of low or no flow punctuated by brief periods of flooding that increase discharge several orders of magnitude within minutes. Although generally more stable than sand channels, some gravel-dominated channels in Arizona are ephemeral or intermittent and subject to flooding for brief periods. Flash flooding and the general instability of the beds of natural channels in Arizona complicate the task of accurately selecting roughness characteristics that may represent conditions during peak flow. Many stream channels in urban areas are manmade and fairly stable. They may be composed of either soil, cement, concrete, riprap, grouted and wire-enclosed rock, firm earth, grass, or a combination of these materials.

The type, distribution, and density of riparian vegetation can vary in the study area. Vegetation types found in and along many streams in central Arizona include saltcedar, willow, cottonwood, mesquite, palo verde, and many shrub and grass species. Effluent-dominated streams in the study area may contain elevated nutrient levels resulting in increased vegetation growth. Vegetation in ephemeral and intermittent streams and constructed channels in central Arizona can be the primary factor in estimating total resistance to flow.

Mean annual precipitation in the study area ranges from about 7 in. near Phoenix to more than 30 in. in adjacent mountain ranges. Precipitation in Arizona mainly occurs during June through October and December through March; rainfall is about equal in each period. Summer precipitation normally is produced by convective thunderstorms. These storms are characterized by rainfall of high intensity and short duration. They usually cover small areas and may result in flash floods. Winter precipitation normally is produced by regional frontal systems that are characterized by low-intensity rainfall of long duration that covers a large areal extent. Dissipating tropical cyclones cause storms in Arizona that occur primarily in September and October (Webb and Betancourt, 1992). These storms can cause record floods of regional extent. 


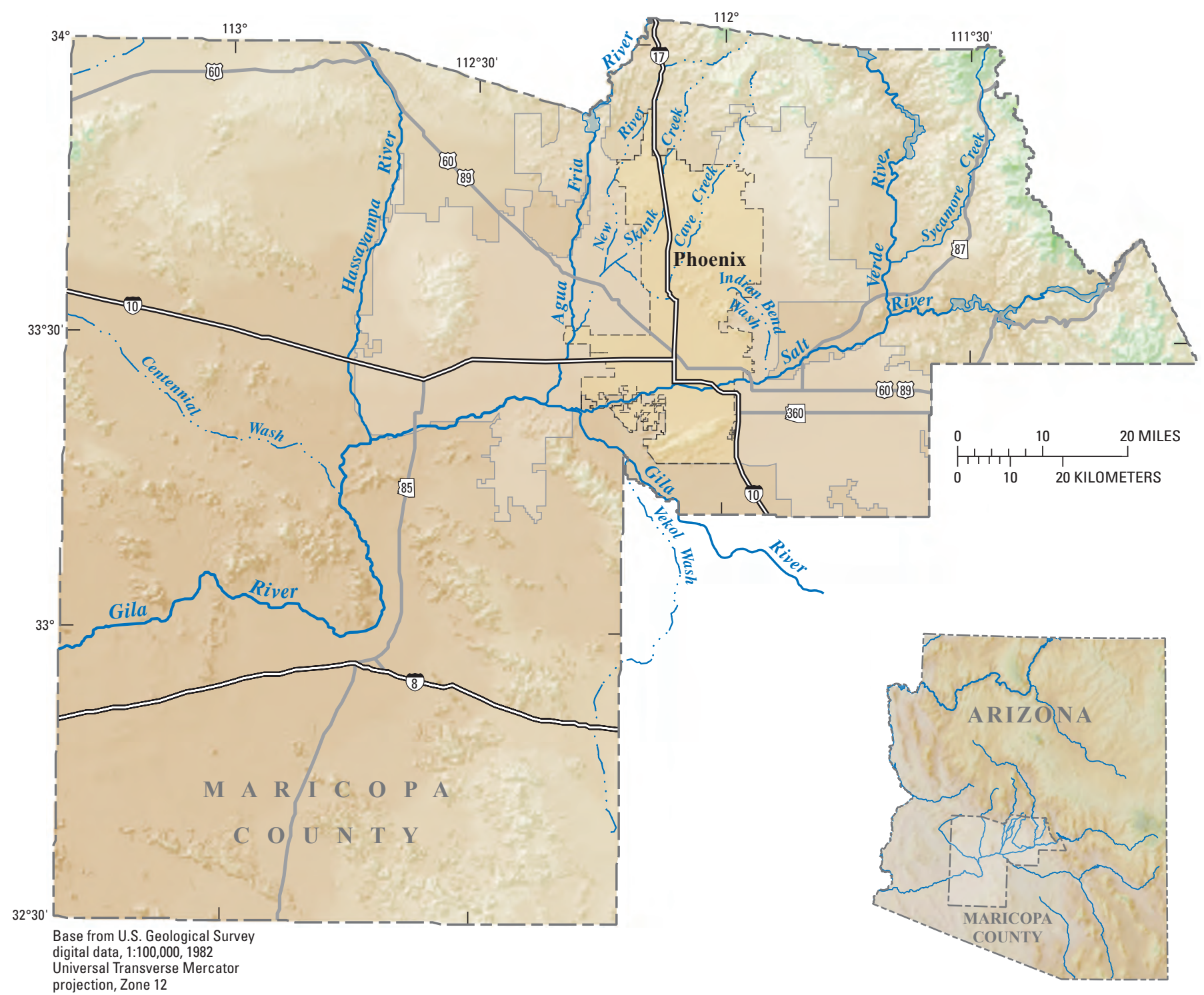

Figure 1. Map showing study area in Maricopa County, Arizona.

\section{Manning's Equation}

Owing to its simplicity of form and to the satisfactory results it lends to practical applications, Manning's equation has become the most widely used of all uniform-flow equations for open-channel flow computations (Chow, 1959). Manning's equation in the following form is commonly used to compute discharge in natural channels:

$$
Q=(1.486 / n) A R^{2 / 3} S_{e}^{1 / 2},
$$

where

$Q$ = discharge, in cubic feet per second,

$A=$ cross-section area of channel, in square feet,

$R=$ hydraulic radius $[A / P$, in feet, where $\mathrm{P}=$ wetted perimeter],

$S_{e}=$ energy gradient, in feet per foot, and

$n$ = Manning's roughness coefficient.

Equation 1 was developed for conditions of uniform flow in which the area, depth, and velocity are constant throughout the reach (Thomsen and Hjalmarson, 1991). The equation is also valid for non-uniform reaches if the energy gradient is modified to reflect only the losses due to boundary friction. In applying Manning's equation, the greatest difficulty lies in the determination of the roughness coefficient, $n$ (Chow, 1959). 


\section{Values of Manning's $n$ For Natural and Constructed Main Channels and Overbank Areas}

Values of Manning's $n$ may be assigned for conditions that exist at the time of a specific flow event, for average conditions over a range in water-flow depths, or for anticipated conditions at the time of some future flow event. The value assigned to a reach should represent the composite effects of the factors that tend to retard flow (Aldridge and Garrett, 1973). In developing the ability to assign $n$ values, a person must rely to a great degree on values that have been verified and on values that have been assigned by experienced personnel (Aldridge and Garrett, 1973; Thomsen and Hjalmarson, 1991).

\section{Base Values of $\boldsymbol{n}$ for Unstable Channels}

An unstable, or sand channel is defined as a channel in which the bed has an unlimited supply of sand (Aldridge and Garrett, 1973). Sand ranges in grain size from 0.062 to $2 \mathrm{~mm}$. Resistance to flow varies greatly in sand channels because the bed material moves easily and takes on different configurations or bed forms. The type of bed form is a function of many components, including velocity of flow, grain size, boundary shear, and other variables. The magnitude of Manning's $n$ may relate directly to the type of bed form that is manifested. The flows that produce the bed forms are classified as lower regime and upper regime flows separated by a transition zone (fig. 2).

The flow regime is governed by the size of the bed material and the stream power, which is a measure of energy transfer. Simons and Richardson (1966) defined stream power (SP) as

$$
S P=62.4 R S_{w} V,
$$

where

62.4 = specific weight of water, in pounds per cubic foot,

$R$ = hydraulic radius, in feet,

$S_{w}=$ water-surface slope, in feet per foot, and

$V=$ mean velocity, in feet per second.

In lower-regime flow, the bed may have a plane surface with little or no movement of sand or small, uniform waves (ripples), or it may have large, irregular waves (dunes) that are formed by sediment moving downstream. Water-surface undulations manifested in lower-regime flow generally are out of phase with the bed surface (fig. 3). The fact that the water surface is out of phase with the bed surface is a positive indication that the flow is tranquil or subcritical (Simons and Richardson, 1966, p. J9).

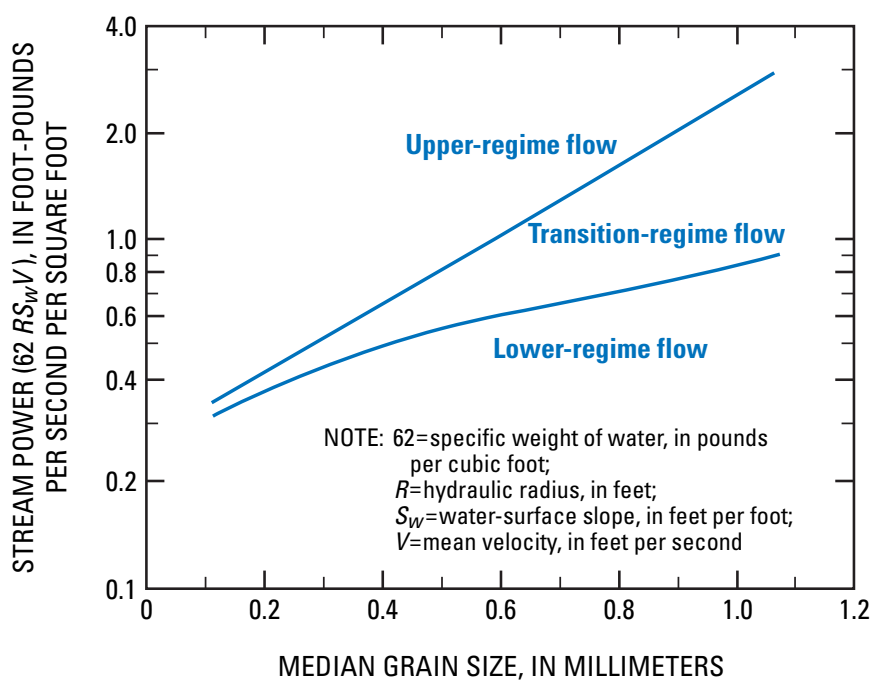

Figure 2. Relation of stream power and median grain size to flow regime.

The bed configuration in the transition-zone regime can be erratic and may manifest bedforms typical to those in upper-regime flow depending mainly on antecedent conditions (Simons and Richardson, 1966, p. J11). Resistance to flow and sediment transport also has the same variability as the bed configuration in the transition zone.

In upper-regime flow, the bed may have a plane surface or it may have long, smooth sand formations in phase with the surface waves (Leopold and others, 1964; Karim, 1995). These surface waves are known as standing waves or antidunes (fig. 3; Simons and Richardson, 1966). As the size of the antidunes grow, the water-surface slope on the upstream side of the waves becomes steeper, and the antidune may eventually collapse. Following collapse of the antidunes, the flow generally will shift back to plane-bed conditions. When antidune formations occur in upper-regime flow and the water and bed surface are in phase, the flow is rapid or supercritical (Simons and Richardson, 1966, p. J9).

The $n$ value for a sand channel is generally assigned for upper-regime flow, and the flow regime is checked by computing the velocity and subsequently the stream power that corresponds to the assigned $n$ value. The computed stream power is compared with the $n$ value necessary to cause upper regime flow.

Aldridge and Garrett (1973, p. 5) suggest that $n$ values for lower- and transitional-regime flows can vary greatly and depend on the bed forms present at a particular time; these values generally will be much larger than the values for upperregime flow. Unfortunately, there is a lack of definition of roughness coefficients available for the lower regime (Benson and Dalrymple, 1967). Most flood peaks on sand channels, however, occur when the bed configuration is in the upper regime (fig. $4 A$ and $B$ ). According to Benson and Dalrymple (1967), the $n$ values for upper-regime flow are dependent on the median grain size of bed material (table 1). 
A. Lower-regime flows

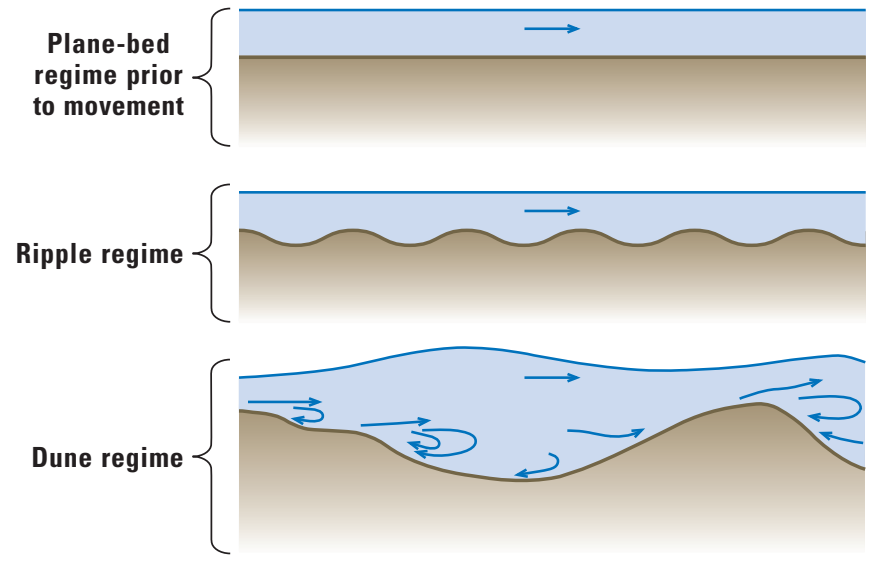

B. Transition-regime flows

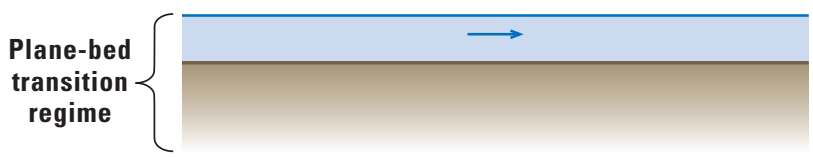

C. Upper-regime flows

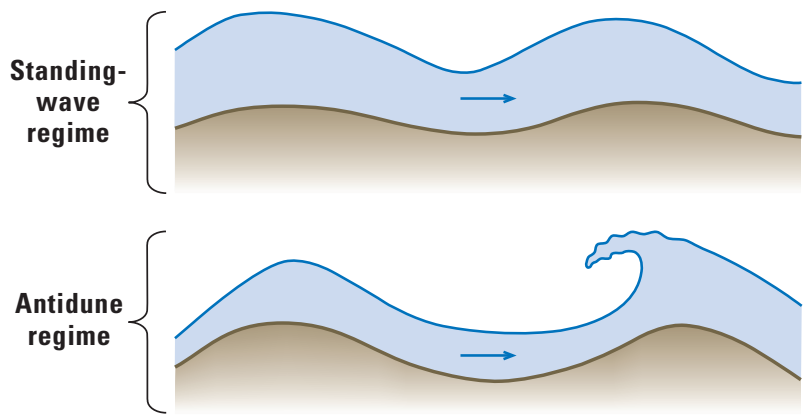

NOTE: Blue arrows denote flow direction

Figure 3. Idealized diagram of bed and surface configurations for alluvial streams for various regimes of flow.

Table 1. Base values of Manning's $n$ for upper-regime flows in sand channels.

[Modified from Benson and Dalrymple (1967)]

\begin{tabular}{cc}
\hline $\begin{array}{c}\text { Median size of bed material, in } \\
\text { millimeters }\end{array}$ & Base $\boldsymbol{n}$ value \\
\hline 0.2 & 0.012 \\
.3 & .017 \\
.4 & .020 \\
.5 & .022 \\
.6 & .023 \\
.8 & .025 \\
1.0 & .026 \\
\hline
\end{tabular}

A. No-flow view

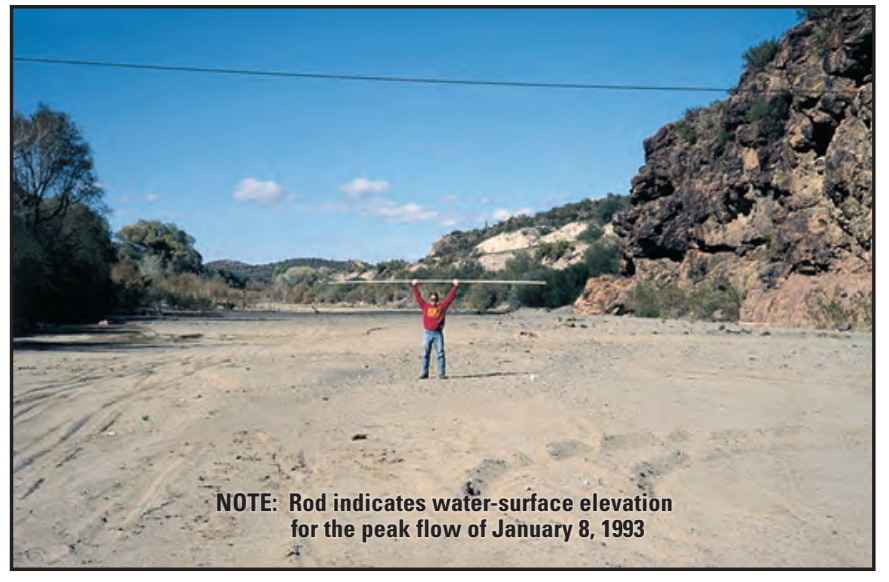

B. Flow view

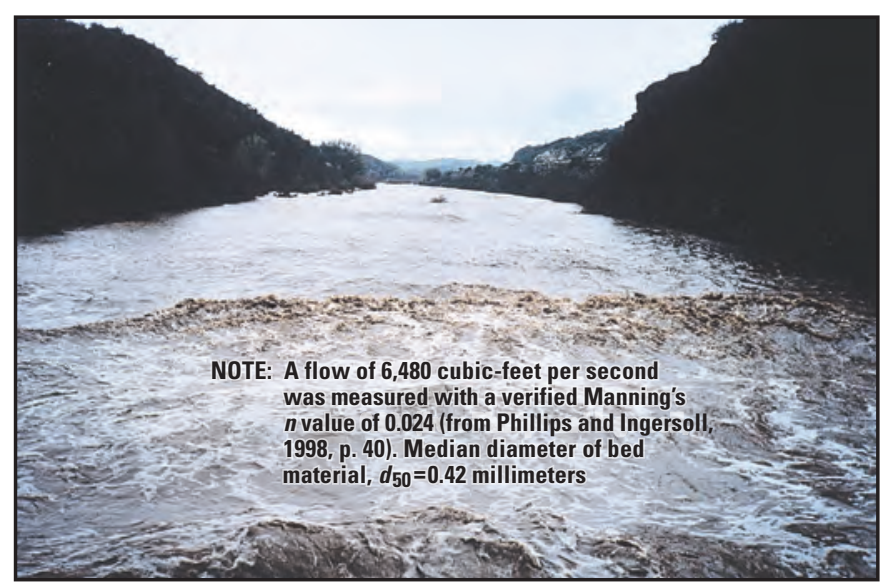

Figure 4. Typical unstable sand channel in central Arizona. $A$, View upstream of midchannel during no-flow period. $B$, View from cableway looking upstream during flow of February 9, 1993.

\section{Base Values of $\boldsymbol{n}$ for Stable Channels}

A stable channel is defined as a channel in which the bed is composed of firm earth, gravel, cobbles, boulders, or bedrock and remains relatively unchanged through most of the range in flow (Aldridge and Garrett, 1973). Base $n$ values for stable channels have been determined mainly from field-verification studies. Base $n$ values for firm earth, gravel, cobble, and boulder channels can be selected by visually comparing the characteristics with those of channels that have known or verified coefficients (Barnes, 1967; Aldridge and Garrett, 1973; Phillips and Ingersoll, 1998), by comparing measured size of bed material with verified values of Manning's $n$ (table 2 ), or by use of equations derived from channel and hydraulic parameters and verified values of Manning's $n$. Base $n$ values for bedrock channels can be selected by visual comparison with bedrock channels where Manning's $n$ has been verified. 
Table 2. Base values of Manning's $n$ for channels considered stable.

\begin{tabular}{|c|c|c|c|c|}
\hline \multirow[t]{2}{*}{ Channel type } & \multicolumn{2}{|c|}{$\begin{array}{c}\text { Median size of bed } \\
\text { material }\end{array}$} & \multicolumn{2}{|c|}{ Base $n$ value } \\
\hline & Millimeters & Inches & $\begin{array}{c}\text { Benson and Dal- } \\
\text { rymple (1967) }\end{array}$ & $\begin{array}{l}\text { Chow } \\
\text { (1959) }\end{array}$ \\
\hline Firm earth & - & - & $0.025-0.032$ & 0.020 \\
\hline Coarse sand & $1-2$ & - & $.026-.035$ & - \\
\hline Fine gravel & - & - & - & .024 \\
\hline Gravel & $2-64$ & $0.08-2.5$ & $.028-.035$ & - \\
\hline Coarse gravel & - & - & - & .028 \\
\hline Cobble & $64-256$ & $2.5-10.5$ & $.030-.050$ & - \\
\hline Boulder & $>256$ & $>10$ & $.040-.070$ & - \\
\hline
\end{tabular}

\section{Equations for selection of base $n$ values for stable channels}

Base $n$ values for stable channels also can be assigned through the use of equations developed from verified channel reaches that relate Manning's $n$ to easily measured hydraulic and channel parameters (eqs. 3 and 4). Several investigators have presented data that indicate trends exist among depth or hydraulic radius, median grain-size diameter, and verified base values of $n$. For example, Limerinos (1970) examined verified values of $n$ for 11 streams in California (fig. 6). Limerinos developed an equation to assign base $n$ values for stable channels that is expressed as

$$
n=\frac{0.0926 R^{1 / 6}}{1.16}+2.0 \log \left(\frac{R}{d_{84}}\right)
$$

where

$R=$ hydraulic radius, in feet, and

$d_{84}=$ intermediate diameter of bed material, in feet, that equals or exceeds that of 84 percent of the particles.

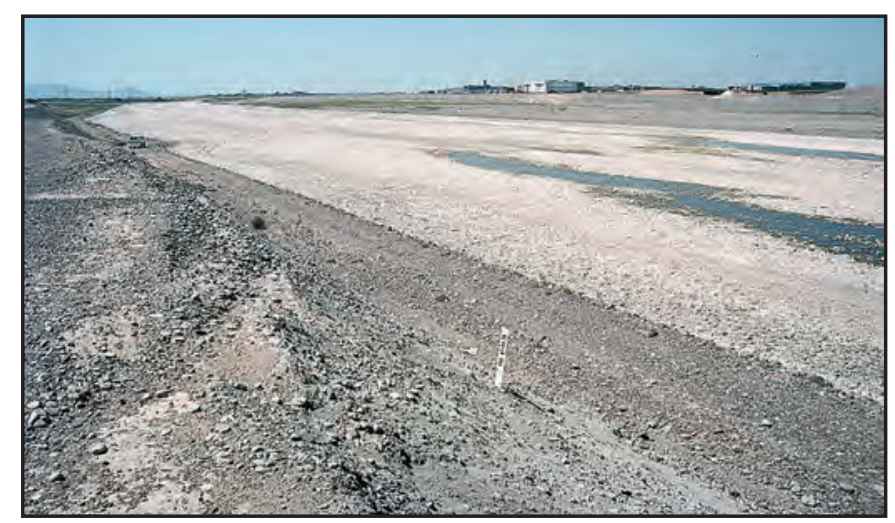

Figure 5. Typical cobble-bed channel in central Arizona for which Manning's $n$ was verified; and used for development of equation 4.
A similar equation was developed for generally lowergradient stable channels in central Arizona for which the base $n$ value was the only perceivable factor that contributed to total roughness (fig. 5; Phillips and Ingersoll, 1998). That equation is in the form of

$$
n=\frac{0.0926 R^{1 / 6}}{1.46}+2.23 \log \left(\frac{R}{d_{50}}\right) \text {, }
$$

where

$d_{50}=$ intermediate diameter of bed material, in feet, that equals or exceeds that of 50 percent of the particles.

The equation was developed by utilizing channels with a median diameter of bed material that ranged from 0.28 to 0.36 foot. These equations have their limitations, but can be utilized as a check or reference for assigning base values of $n$.

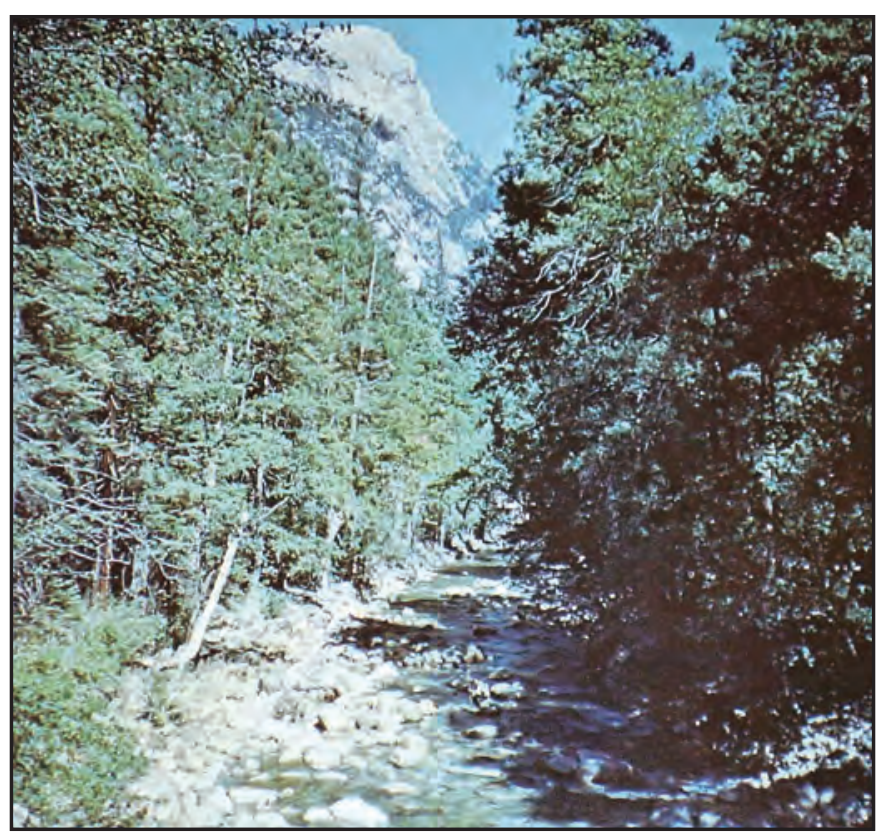

Figure 6. Typical high-gradient cobble-bed channel in California for which Manning's $n$ was verified and utilized for development of equation 3.

\section{Flow Depth and Channel Gradient}

Previous investigations indicate there is a relation between depth of flow and $n$ values (Jarrett, 1985; Phillips and Ingersoll, 1998). In the absence of bank vegetation and other obstructions, the roughness coefficient for flows in a uniform stable streambed generally decreases with increasing depth of flow (eqs. 3 and 4). With increased flow depth, the energy losses associated with the channel-bed roughness elements generally become less significant. As flow approaches bankfull stage, the roughness coefficient may approach a constant 
value for a given median bed-size material (Limerinos, 1970; Jarrett, 1985; Phillips and Ingersoll, 1998).

Channel roughness seems to be directly related to channel gradient or slope (Riggs, 1976; Jarrett, 1985). Channels with low gradients have been shown to have lower roughness coefficients than channels with high gradients (Jarrett, 1985). Because of the relation between channel slope, size of bed material, and energy losses, the effect of slope on $n$ should be considered in the selection of base $n$ values (Aldridge and Garrett, 1973). Information presented by Jarrett (1985) can be used as a reference for selecting $n$ values that may be impacted by the channel gradient.

\section{Values and Descriptions For Components of Manning's $n$}

The general procedure for determining $n$ values is to select a base value of $n$ for the bed material (tables 1 and 2) and then select $n$-value adjustments for channel irregularities, alignment, obstructions, vegetation, and other factors (table 3; Cowen, 1956). Utilizing this procedure, the value of $n$ is computed as follows

$$
n=\left(n_{0}+n_{1}+n_{2}+\ldots+n_{n}\right) m,
$$

where

$$
n_{\mathrm{o}}=\text { base value of } n \text { for a straight, uniform chan- }
$$
nel,

$n_{1}, n_{2}, \ldots, n_{\mathrm{n}}=$ adjustments for roughness factors other than meanders; and

$m$ = adjustment for meanders.

\section{Degree of Channel Irregularity}

The impact of channel irregularity may be negligible where channel margins are extremely smooth (fig. 7). Roughness caused by eroded and scoured banks, projecting points, and exposed tree roots along the channel margins, however, can be accounted for by adding adjustments to the base value of $n$ (figs. 8 and 9). Chow (1959) and Benson and Dalrymple (1967) indicate that severely eroded and scoured banks can increase $n$ values by as much as 0.020 (fig. 10; table 3).

\section{Variation in Channel Cross Section}

Gradual changes in the size and shape of a channel cross section should have no impact on energy losses (fig. 11). Where large and small cross sections alternate occasionally, or the main flow occasionally shifts from side to side, adjustments to the base $n$ value can range from 0.001 to 0.005 . Chow (1959) gave a maximum increase of 0.015 in channels where large and small cross sections alternate frequently or where the low-water channel frequently shifts from side to side (table 3 ).

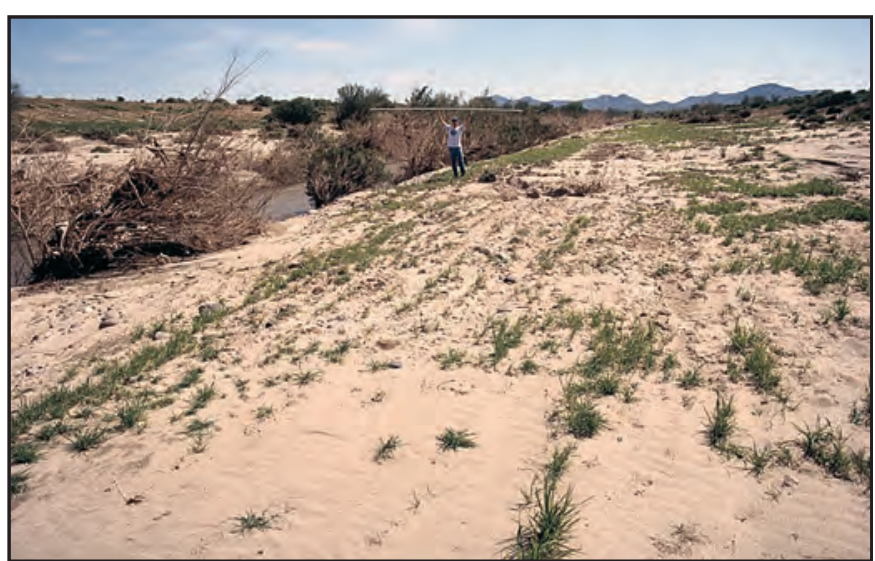

Figure 7. The Manning $n$ component for channel bank is considered smooth with a corresponding component of 0.000 (table 3).

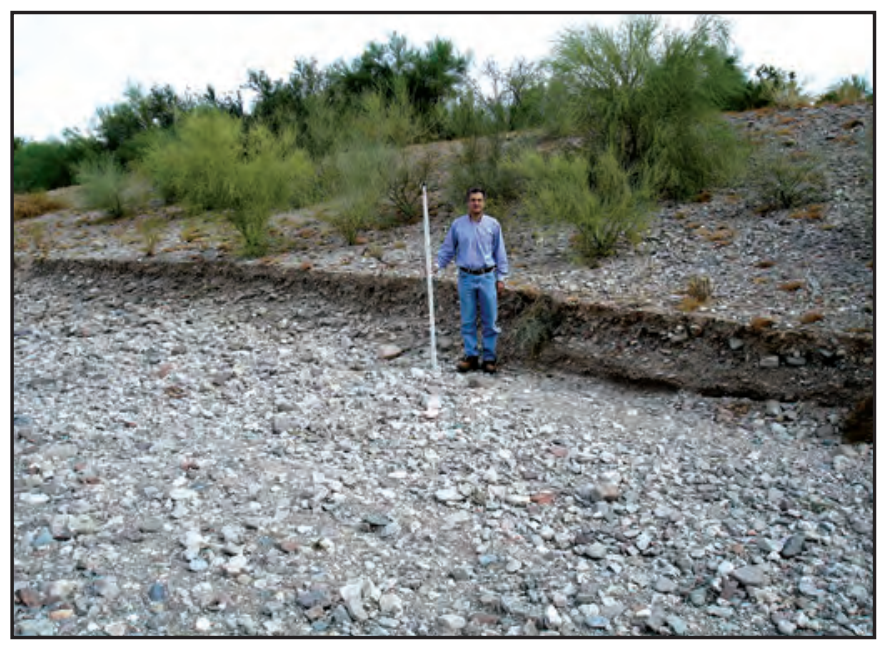

Figure 8. The Manning $n$ component for the eroded and scoured banks is considered moderate with a range of 0.006 to 0.010 (table 3).

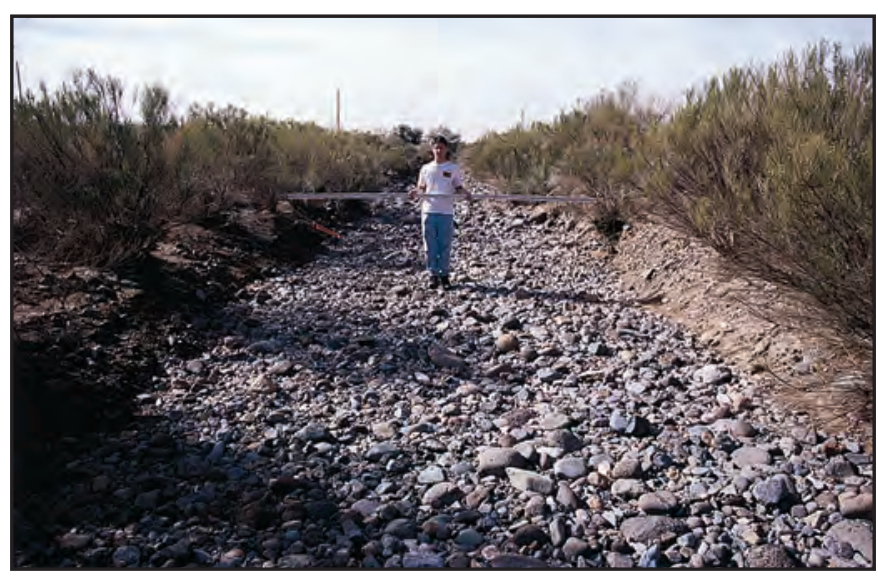

Figure 9. The Manning $n$ component for the eroded and slightly scoured banks is considered minor with a range of 0.001 to 0.005 (table 3). 
Table 3. Adjustment factors or component ranges for various channel conditions used to determine Manning's $n$ values.

[Adjustment to degree of meandering values apply to flow confined in the channel and does not apply where flow crosses meanders; Modified from Cowen, 1956; and Chow, 1959]

\begin{tabular}{|c|c|c|}
\hline $\begin{array}{l}\text { Channel } \\
\text { conditions }\end{array}$ & $\begin{array}{l}\text { Manning's } n \\
\text { adjustment }\end{array}$ & Example \\
\hline \multicolumn{3}{|r|}{ Degree of irregularity } \\
\hline Minor & $.001-.005$ & Channels with slightly scoured or eroded side slopes. \\
\hline Moderate & $.006-.010$ & Channels with moderately sloughed or eroded side slopes. \\
\hline Gradual & .000 & Size and shape of channel cross sections change gradually. \\
\hline $\begin{array}{l}\text { Alternating oc- } \\
\text { casionally }\end{array}$ & $.001-.005$ & $\begin{array}{l}\text { Large and small cross sections alternate occasionally, or the main flow occasionally shifts from side to side owing to } \\
\text { changes in cross-section shape. }\end{array}$ \\
\hline $\begin{array}{l}\text { Alternating } \\
\text { frequently }\end{array}$ & $.010-.015$ & $\begin{array}{l}\text { Large and small cross sections alternate frequently, or the main flow frequently shifts from side to side owing to changes in } \\
\text { cross-section shape. }\end{array}$ \\
\hline Minor & $.005-.015$ & $\begin{array}{l}\text { Obstructions occupy from } 5 \text { to } 15 \text { percent of the cross-section area and spacing between obstructions is such that the sphere } \\
\text { of influence around one obstruction does not extend to the sphere of influence around another obstruction. Smaller } \\
\text { adjustments are used for curved, smooth-surfaced objects than are used for sharp-edged, angular objects. }\end{array}$ \\
\hline Appreciable & $.020-.030$ & $\begin{array}{l}\text { Obstructions occupy from } 15 \text { to } 50 \text { percent of the cross-section area, or the space between obstructions is small enough to } \\
\text { cause the effects of severe obstructions to be additive, thereby blocking an equivalent part of a cross section. }\end{array}$ \\
\hline Severe & $.040-.060$ & $\begin{array}{l}\text { Obstructions occupy more than } 50 \text { percent of the cross-section area, or the space between obstructions is small enough to } \\
\text { cause turbulence across most of the cross section. }\end{array}$ \\
\hline \multicolumn{3}{|r|}{ Amount of vegetation } \\
\hline Negligible & $.000-.002$ & Grass, shrubs, or weeds were permanently laid over during flow. \\
\hline Large & $.025-.050$ & $\begin{array}{l}\text { 8- to } 10 \text {-year-old willow, cottonwood, mesquite or palo verde trees (block flow by approximately } 10 \text { to } 30 \text { percent where } \\
\text { the sphere's of influence overlap) intergrown with some weeds and brush where the hydraulic radius exceeds } 2 \text { feet. }\end{array}$ \\
\hline Very large & $.050-.100$ & $\begin{array}{l}\text { Bushy willow trees about } 1 \text {-year old intergrown with weeds alongside slopes or dense cattails growing along the channel } \\
\text { bottom; trees intergrown with weeds and brush. Moderately dense (blocks flow by approximately } 30 \text { to } 50 \text { percent and } \\
\text { the sphere's of influence overlap) 8- to 10-year old trees spaced randomly throughout channel where depth of flow ap- } \\
\text { proximates height of vegetation. }\end{array}$ \\
\hline $\begin{array}{l}\text { Extremely } \\
\text { large }\end{array}$ & $.100-.200$ & $\begin{array}{l}\text { Mature (greater than } 10 \text { years old) willow trees and tamarisk intergrown with brush and blocking flow by more than } 70 \\
\text { percent of the flow area, causing turbulence across most of the section. Depth of flow is less than average height of the } \\
\text { vegetation. Dense stands of palo verde or mesquite that block flow by } 70 \text { percent or more and hydraulic radius is about } \\
\text { equal to or greater than average height of vegetation. }\end{array}$ \\
\hline \multicolumn{3}{|r|}{ Degree of meandering } \\
\hline Minor & 1.00 & Ratio of the channel length to valley length is 1.0 to 1.2 . \\
\hline Appreciable & 1.15 & Ratio of the channel length to valley length is 1.2 to 1.5 . \\
\hline Severe & 1.30 & Ratio of the channel length to valley length is greater than 1.5 . \\
\hline
\end{tabular}




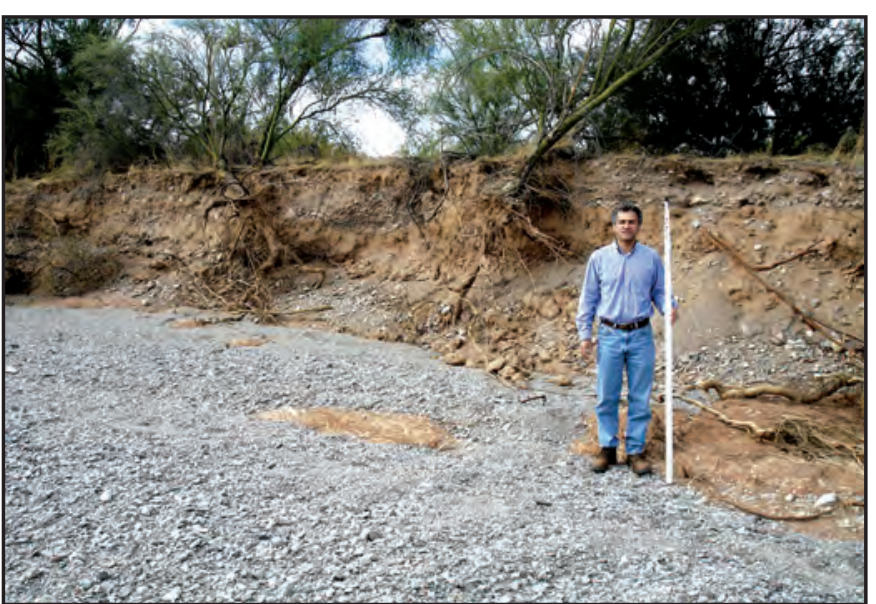

Figure 10. The Manning $n$ component for the sloughed banks; jagged and irregular surfaces is considered severe with a range of 0.011 to 0.020 (table 3).

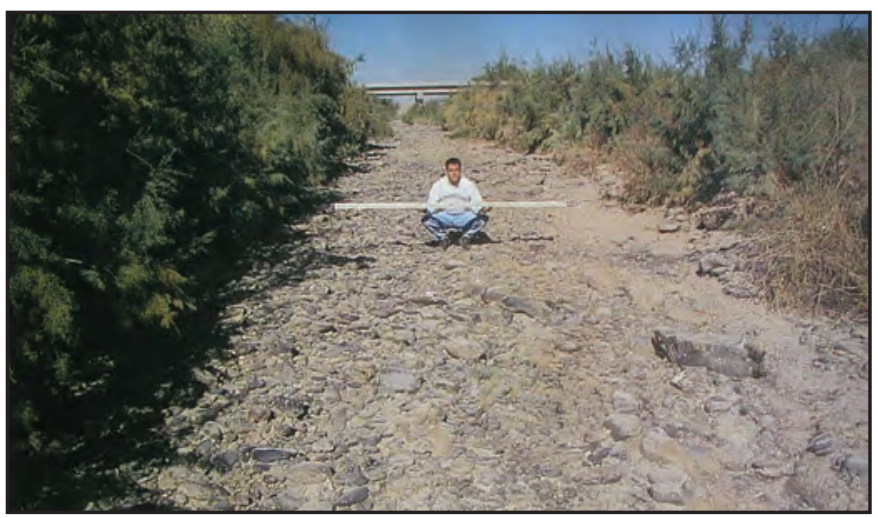

Figure 11. Channel reach where the size and shape of sections change gradually. The Manning $n$ component for this example is considered negligible or 0.000 (table 3).

\section{Effect of Obstructions}

Isolated boulders, debris deposits, logs, power poles and towers, and bridge piers that disturb the flow pattern in the channel increase energy losses, or $n$ values (figs. 12-16). The amount of increase depends on the shape of the obstruction, its size in relation to other roughness elements in the cross section, the number, arrangement, and spacing of the obstructions, and the magnitude of flow velocity (Aldridge and Garrett, 1973). When the flow velocity is high, an obstruction exerts a sphere of influence that can be much larger than the obstruction because the obstruction can affect the flow pattern for considerable distances on each side. At velocities that generally occur in channels that have gentle to moderately steep slopes, the sphere of influence is about 3 to 5 times the width of the obstruction (fig. 12; Aldridge and Garrett, 1973). Several obstructions create overlapping spheres of influence and can cause considerable disturbance and loss of energy even though the obstructions may occupy only a small part of the cross section. Aldridge and Garrett (1973) assigned values to four degrees of obstructions (table 3 ).

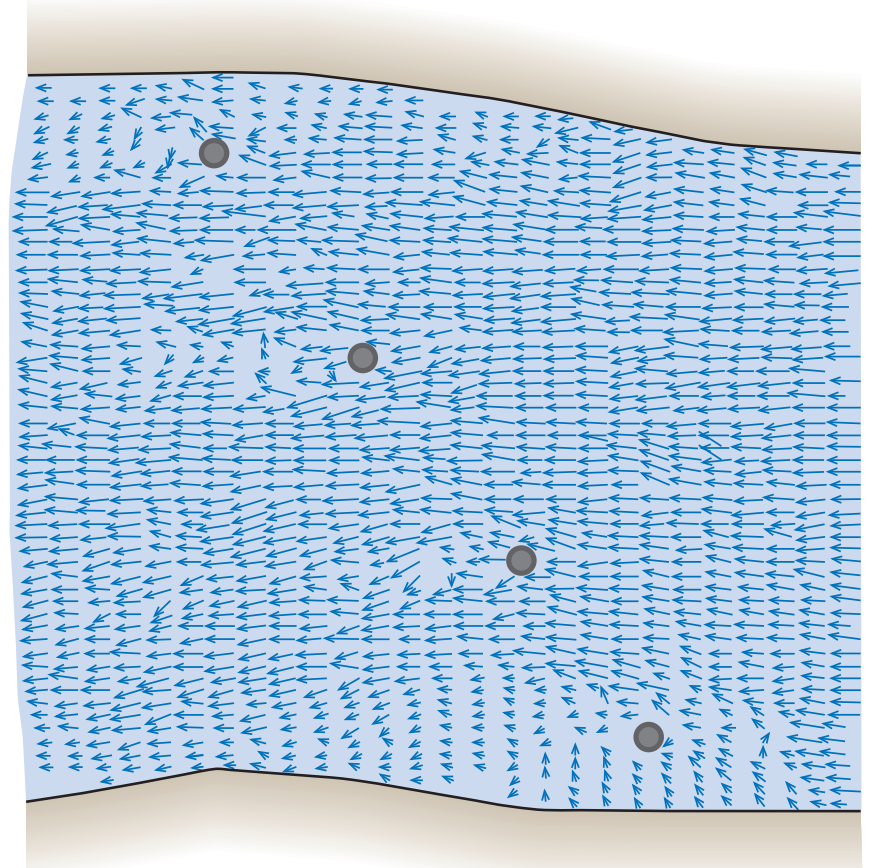

Figure 12. General flow disturbance caused by bridge piers at Colorado River near Moab, Utah.

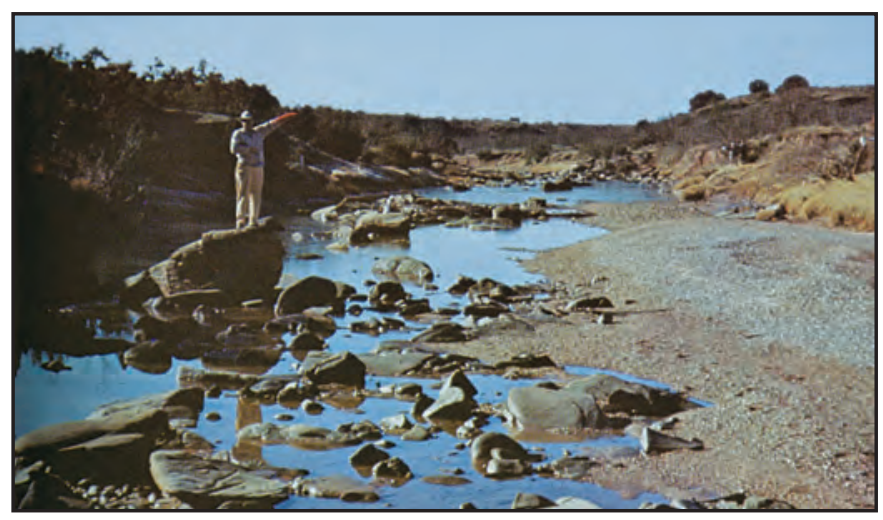

Figure 13. Large angular boulder in mid channel.

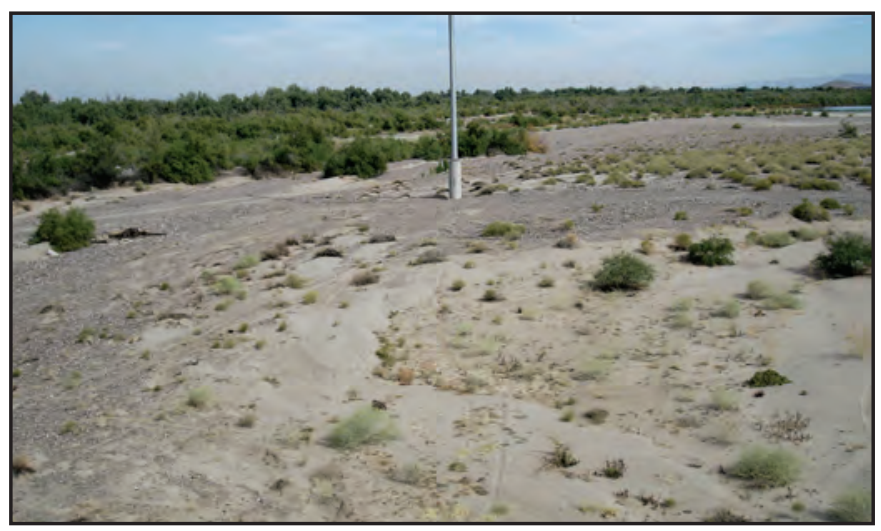

Figure 14. Power pole obstructing less than 5 percent of the channel area. The Manning's $n$ component for the obstruction is considered negligible, with a corresponding range in $n$ of 0.000 to 0.004 (table 3). 


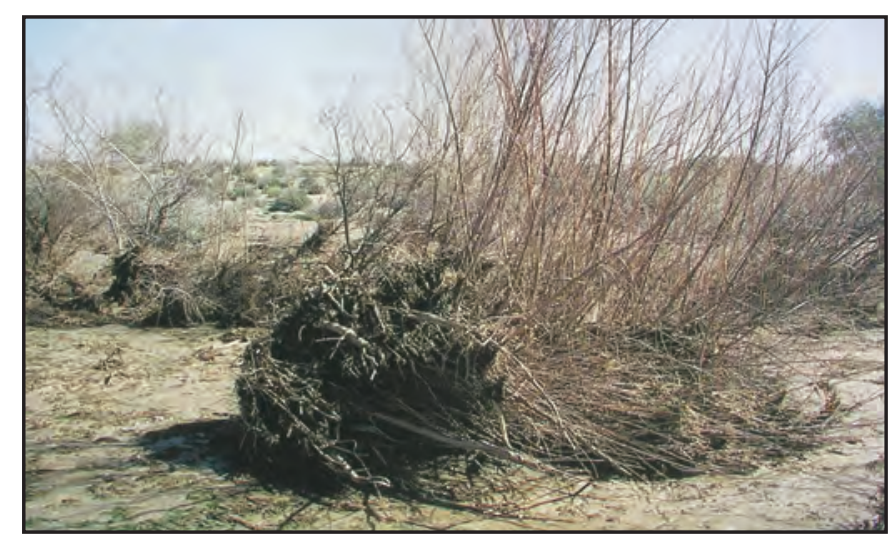

Figure 15. Removed brush caught on more flow resistant vegetation resulting in a localized angular obstruction with a larger sphere of influence than the resistant vegetation alone.

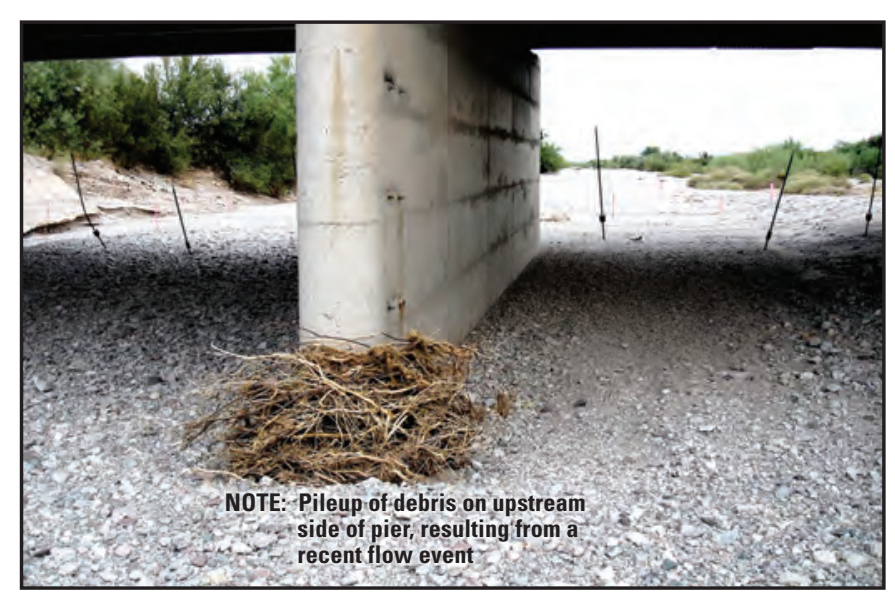

Figure 16. Bridge pier for which the Manning's $n$ component is considered to range from 0.005 to 0.015 (table 3).

\section{Amount of Vegetation}

The degree to which vegetation affects flow depends on the depth of flow relative to vegetation height, the percentage of flow obstructed by the vegetation, the degree to which vegetation is affected or flattened by high water, and the alignment of vegetation relative to the flow (figs. 17-24; Phillips and others, 1998). In wide channels having small depth to width ratios and no vegetation on the channel bed, the effect of bank vegetation is generally small, and the maximum adjustment is about 0.005 . If the channel is relatively narrow and has steep banks covered by dense vegetation that hangs over the channel, the maximum adjustment would be about 0.030 . The larger adjustment values given in table 3 apply primarily in places where vegetation covers most of the main channel. If vegetation is the primary factor that affects $n$, as in flood plains, in parts of a channel that are seldom flooded, or in the main channel of ephemeral or intermittent streams, the $n$ value is assigned for the vegetation rather than for the material in which it is growing (Thomsen and Hjalmarson, 1991).
Similar to the impact of obstructions on energy losses, at flow velocities that generally occur in channels that have gentle to moderately steep slopes, the sphere of influence can be about 3 to 5 times the width of the vegetation. Closely clumped trees or reaches where flow-resistant vegetation blocks flow by more than 50 percent of the cross sectional area can create overlapping spheres of influence and can cause considerable disturbance and loss of energy with $n$-value adjustments that range from 0.050 to 0.200 (table 3 ).

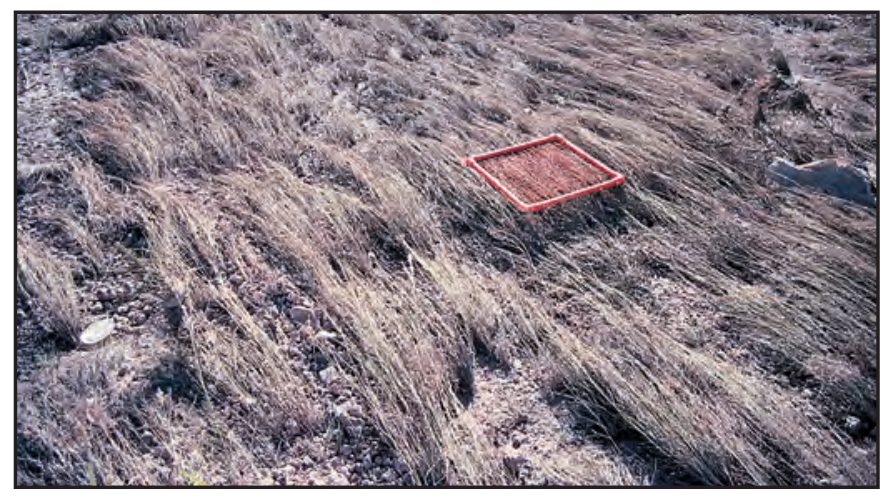

Figure 17. Tall grass laid over as a result of a flow of 6,480 cubic feet per second.

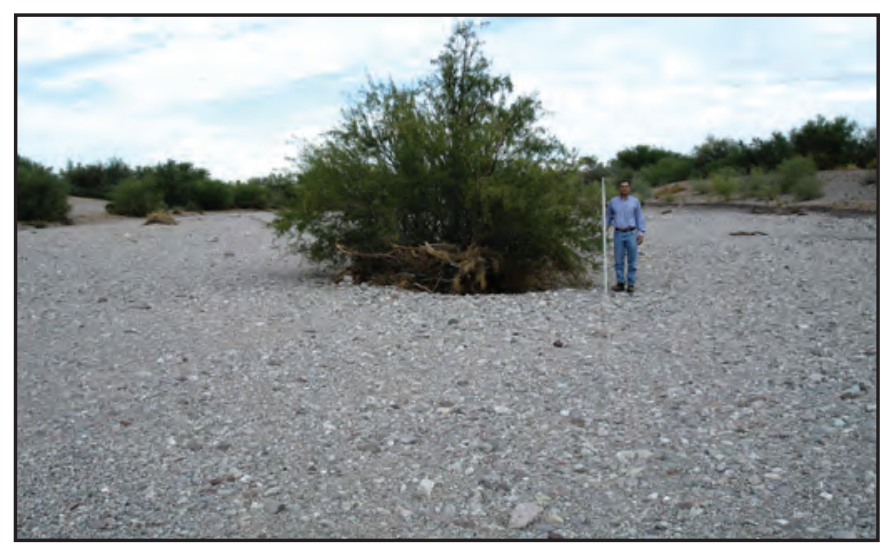

Figure 18. Lone tree that is approximately 20 feet in height.

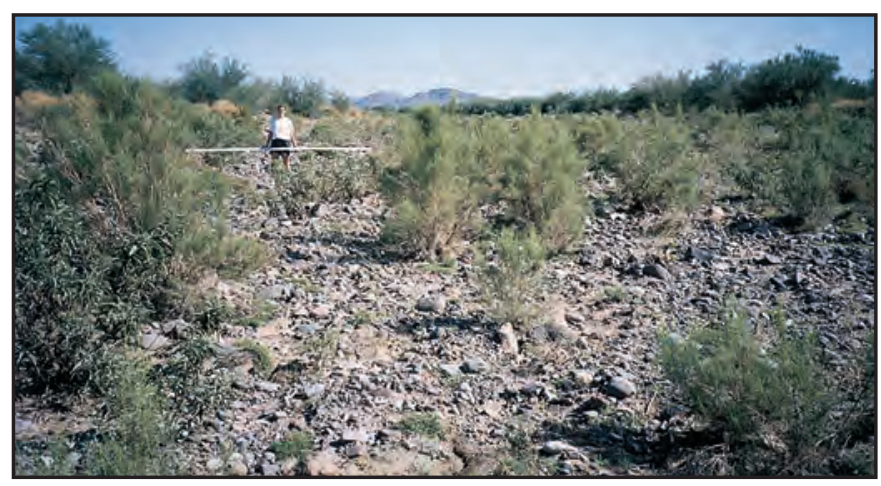

Figure 19. Randomly scattered shrubs. Flow elevation approximated level of the survey rod for a discharge of 403 cubic feet per second. 


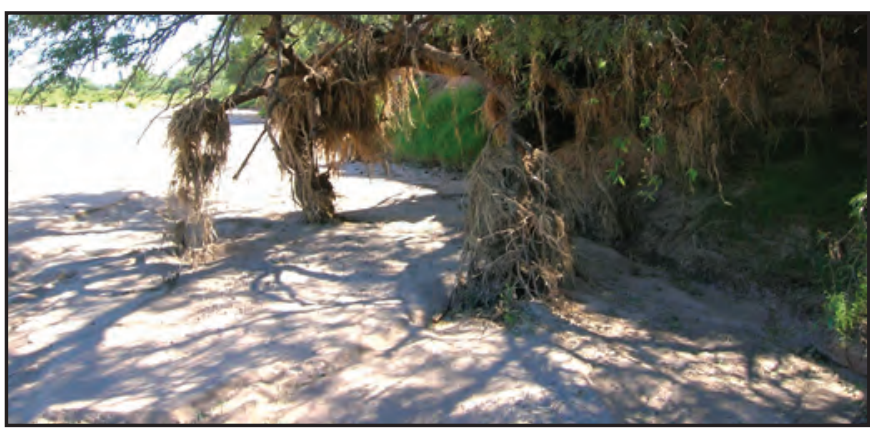

Figure 20. Large mesquite with branches that hang over the main-channel area.

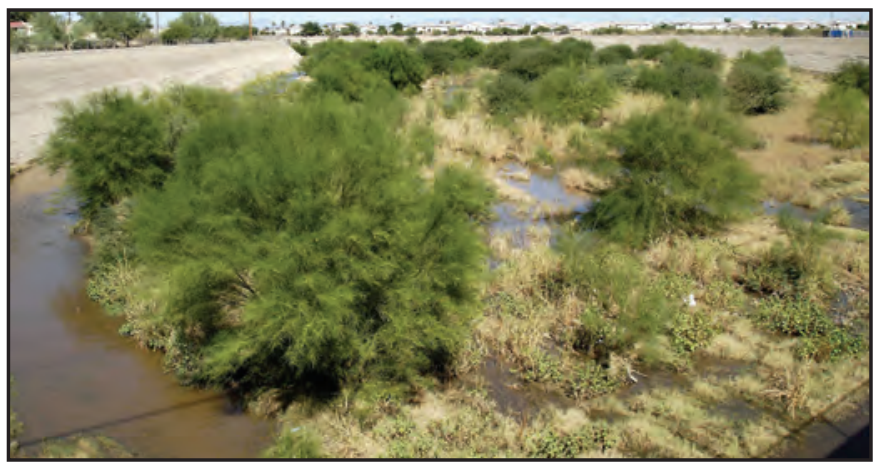

Figure 21. Randomly distributed mesquite and palo verde approximately 15 to 20 feet in height (table 3 ).

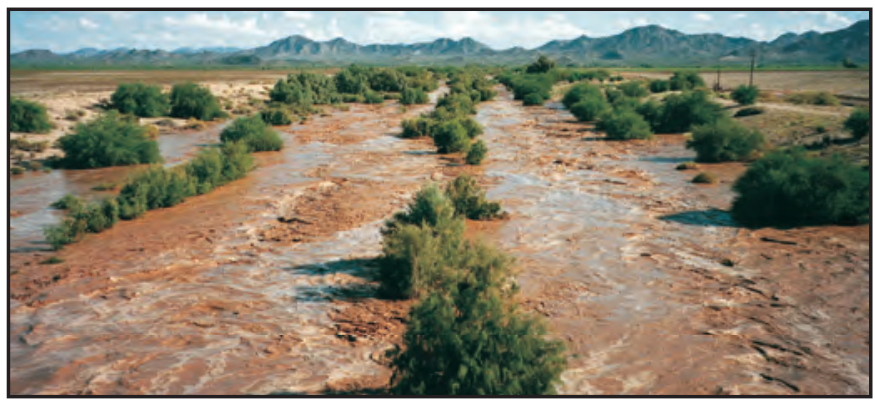

Figure 22. Image showing flow altered by vegetation (table 3).

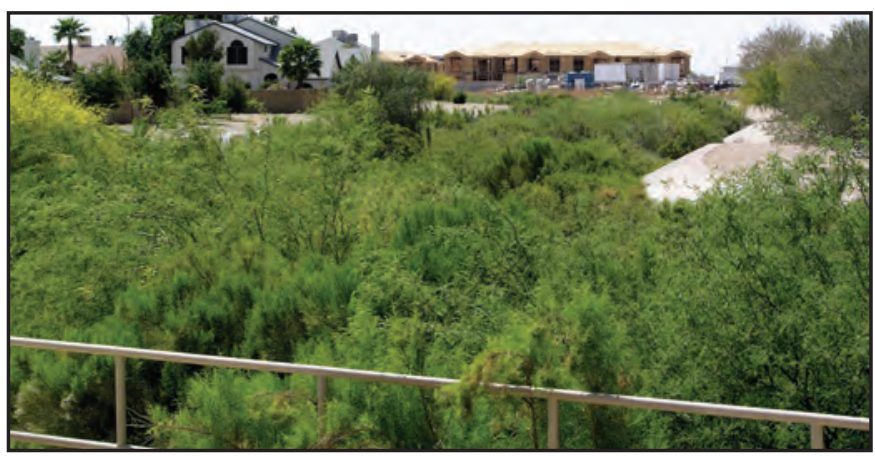

Figure 23. The Manning $n$ component for the vegetation is considered extremely large, with a corresponding range in $n$ of 0.100 to 0.200 (table 3 ).
A. View before flood event

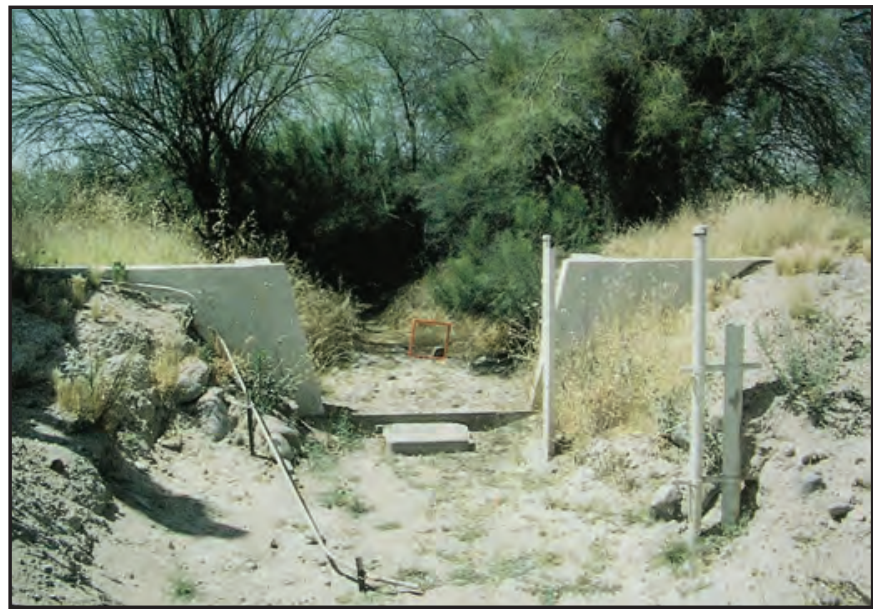

\section{$B$. View of flooding}

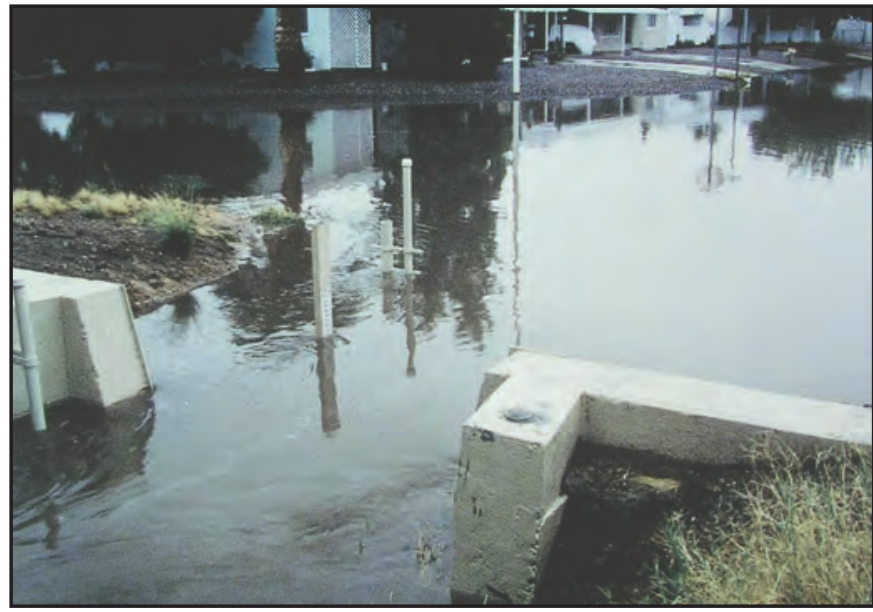

Figure 24. Extremely dense vegetation in the channel that drains this urban area. $A$, Downstream from midchannel before the flow of December 10, 1991. $B$, upstream from left bank during the flow of December 10, 1991.

Utilizing verified roughness coefficients for a site in central Arizona (Skunk Creek above Interstate 17), Phillips and Ingersoll (1998) developed a semi-empirical relation for non-submerged and randomly-distributed shrubs. The relation or equation is in the form of

$$
n_{\text {veg }}=0.0008 B-0.0007,
$$

where

$$
\begin{aligned}
n_{v e g} & =\text { vegetation component of Manning's } n, \text { and } \\
B & =\text { percentage of flow blocked by vegetation. }
\end{aligned}
$$

Use of the equation is somewhat limited to channel and vegetation conditions similar to those in Skunk Creek above Interstate 17, Arizona (fig. 19; Phillips and Ingersoll, 1998). Extrapolations to other channels with similar types of flow, channel, and vegetation conditions can be made, but should be done so with caution. 


\section{Values of Manning's $n$ For Agriculture or Overbank Areas}

Values of $n$ for fields with crops, as well as for natural vegetation in overbank areas, can be selected on the basis of the work of Chow (1959; table 4). Mature cotton plants are comparable to dense brush in the summer, and defoliated cotton is comparable to medium to dense brush in the winter (fig. $25 A$ and $B$ ). For overbank areas, the value of $n$ generally varies with the stage of submergence of the vegetation (Thomsen and Hjalmarson, 1991). In general, higher stages should result in lower Manning's $n$ values.

Table 4. Values of Manning's $n$ for agriculture or overbank areas.

[Modified from Chow (1959) and Thomsen and Hjalmarson (1991)]

\begin{tabular}{|c|c|c|c|}
\hline \multirow[b]{2}{*}{ Description } & \multicolumn{3}{|c|}{ Manning's $n$} \\
\hline & Minimum & Normal & Maximum \\
\hline \multicolumn{4}{|c|}{ Pasture, no brush } \\
\hline Short grass & 0.025 & 0.030 & 0.035 \\
\hline High grass & .030 & .035 & .050 \\
\hline \multicolumn{4}{|c|}{ Cultivated areas } \\
\hline No crop & .020 & .030 & .040 \\
\hline Mature row crops & .025 & .035 & .045 \\
\hline Mature field crops & .030 & .040 & .050 \\
\hline \multicolumn{4}{|c|}{ Shrubs } \\
\hline $\begin{array}{l}\text { Scattered shrubs, } \\
\text { heavy weeds }\end{array}$ & .035 & .050 & .070 \\
\hline $\begin{array}{l}\text { Light shrubs and trees, } \\
\text { in winter }\end{array}$ & .035 & .050 & .060 \\
\hline $\begin{array}{l}\text { Light shrubs and trees, } \\
\text { in summer }\end{array}$ & .040 & .060 & .080 \\
\hline $\begin{array}{l}\text { Medium to dense shrubs, } \\
\text { in winter }\end{array}$ & .045 & .070 & .110 \\
\hline $\begin{array}{l}\text { Medium to dense shrubs, } \\
\text { in summer }\end{array}$ & .070 & .100 & .160 \\
\hline \multicolumn{4}{|c|}{ Trees } \\
\hline $\begin{array}{l}\text { Dense willows, mesquite, } \\
\text { saltcedar }\end{array}$ & .110 & .150 & .200 \\
\hline $\begin{array}{l}\text { Cleared land with tree } \\
\text { stumps, no sprouts }\end{array}$ & .030 & .040 & .050 \\
\hline $\begin{array}{l}\text { Same as above, but heavy } \\
\text { growth of sprouts }\end{array}$ & .050 & .060 & .080 \\
\hline $\begin{array}{l}\text { Heavy stand of timber, a few } \\
\text { down trees, little under- } \\
\text { growth, flood stage below } \\
\text { branches }\end{array}$ & .080 & .100 & .120 \\
\hline $\begin{array}{l}\text { Same as above, but with } \\
\text { flood stage reaching } \\
\text { branches }\end{array}$ & .100 & .120 & .160 \\
\hline
\end{tabular}

\section{A. Mature cotton}

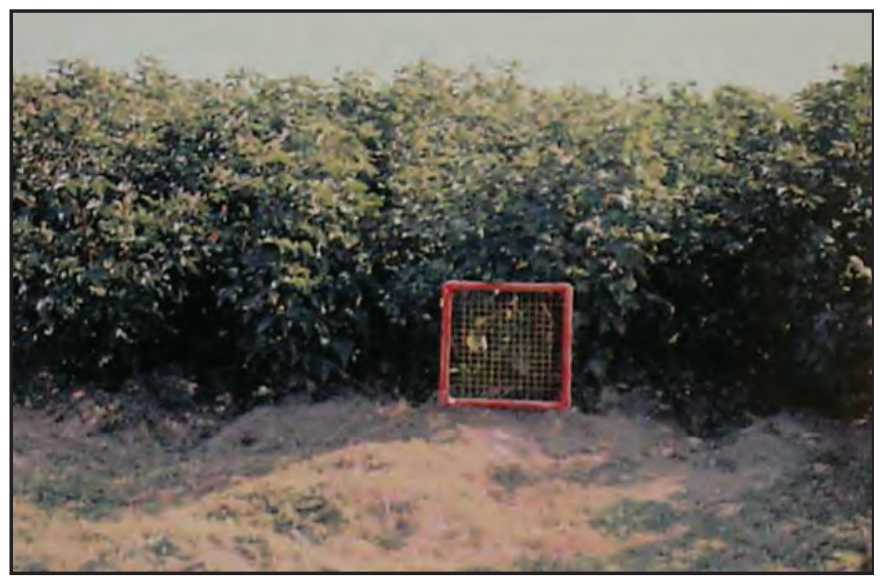

\section{B. Defoliated cotton}

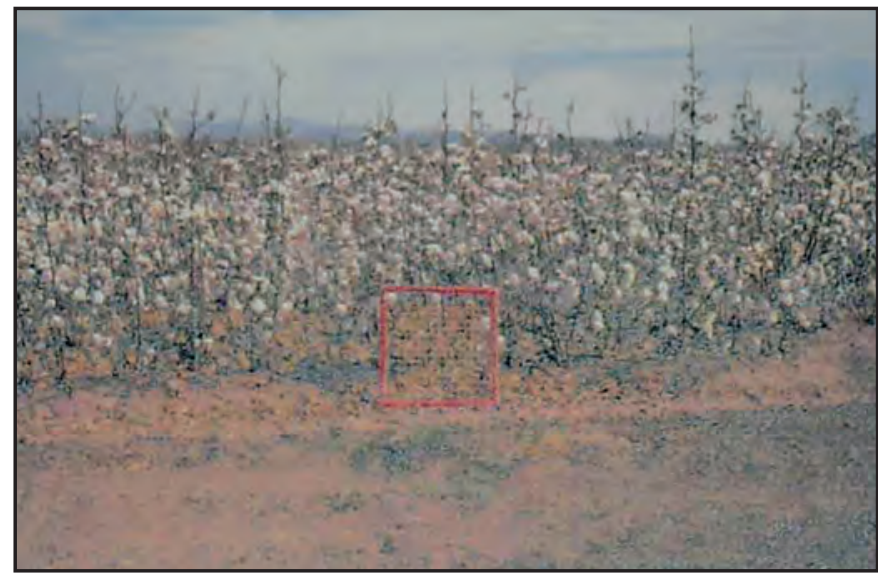

Figure 25. Fields of $A$, Mature cotton in the summer and $B$, defoliated cotton in the fall.

\section{Composite Values of $\boldsymbol{n}$ For Constructed Channels}

Composite values of $n$ are presented in table 5 for various types of stable constructed channels. The degree of the $n$ value for a selected channel type is related to the newness of the channel and degree of subsequent maintenance (fig. 26A and $B)$. For example, minimum values correspond to new construction, normal values correspond to good maintenance, and the maximum $n$ value corresponds to deteriorated or poor maintenance. 


\section{$A$. Channel survey}

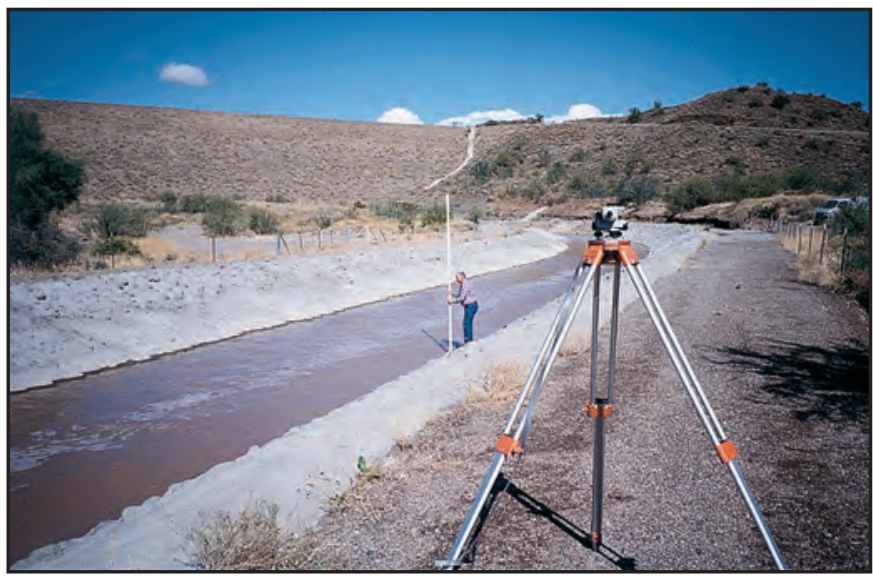

$B$. Channel conditions following flow

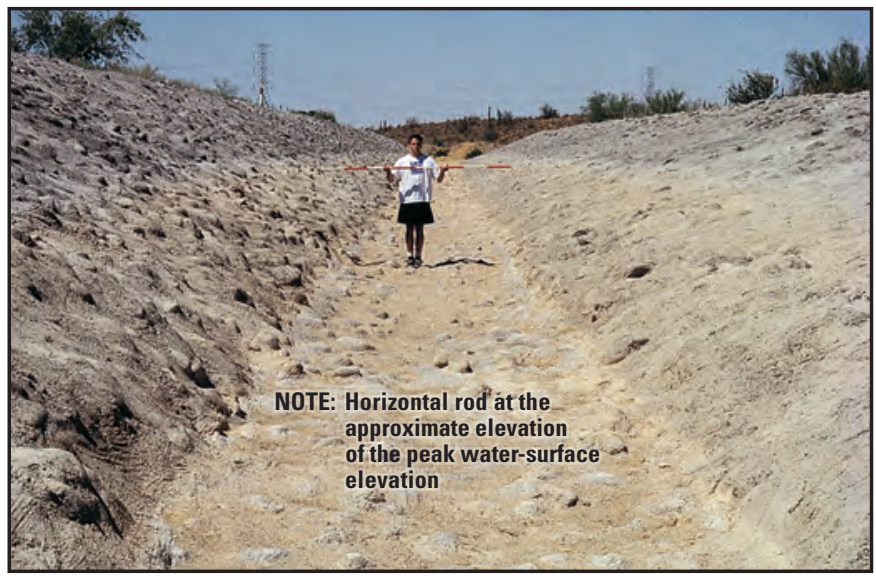

Figure 26. Manning's $n$-verification measurement made at a well-maintained constructed channel (Phillips and Ingersoll, 1998). A, Channel survey made for verification of Manning's $n$. $B$, Channel conditions following flow.

\section{Procedure For Subdivision of Cross Sections}

The Manning's equation was designed for uniform steady flow in trapezoid channels. Most natural channels, however, are not uniform. The hydrologist or engineer using Manning's equation, therefore, should be aware of its shortcomings and use reasonable judgment to come up with the best results (Cruff, 1999). One of the largest shortcomings of the equation when working with natural channels, and even some constructed channels, is the change in energy loss, or $n$, across or perpendicular to the channel. Because of these changes there is a tendency to subdivide the channel section at changes in roughness. This subdivision method can greatly affect the computation for hydraulic radius, $R$, and significantly and erroneously impact the final computations.
Table 5. Composite values of $n$ for stable constructed channels.

[Modified from Chow (1959)]

\begin{tabular}{lrrr}
\hline \multicolumn{1}{c}{ Type of channel and description } & Minimum & $\begin{array}{c}n \text { value } \\
\text { Normal }\end{array}$ & Maximum \\
\hline $\begin{array}{l}\text { A. LINED OR BUILT-UP CHANNELS } \\
\text { a. Concrete }\end{array}$ & & & \\
$\quad$ 1. Finished & 0.011 & 0.015 & 0.016 \\
$\quad$ 2. Unfinished & .014 & .017 & .020 \\
b. Gravel bottom with sides of & & & \\
$\quad$ 1. Formed concrete & .017 & .020 & .025 \\
2. Random stone in mortar & .020 & .023 & .026 \\
3. Dry rubble or riprap & .023 & .033 & .036
\end{tabular}

B. EVACUATED OR DREDGED CHANNELS

a. Earth, straight and uniform

$\begin{array}{llll}\text { 1. Clean, after weathering } & .018 & .022 & .025 \\ \text { 2. Gravel, uniform section, clean } & .022 & .025 & .033\end{array}$

b. Earth, winding and sluggish

1. Earth bottom and rubble sides $\quad .028 \quad .030 \quad .035$

2. Stony bottom $\quad .025 \quad .035 \quad .040$

3. Cobble bottom and clean sides $\quad .030 \quad .040 \quad .050$

c. Rock cuts

$\begin{array}{llll}\text { 1. Smooth and uniform } & .025 & .035 & .040 \\ \text { 2. Jagged and irregular } & .035 & .040 & .050\end{array}$

In most cases the main channel should not be subdivided, and an average $n$ should be selected (Cruff, 1999). Cross sections with distinct changes in shape, however, should be subdivided into subsections and the $n$ values determined separately for each subsection. In this manner the Manning's equation will solve a series of near rectangular or trapezoidal channels, which can produce much more accurate results (Davidian, 1984). Cross sections should be subdivided if the flow-depth in the main-channel is greater than or equal to twice the flow depth at the stream edge of the overflow area (Thomsen and Hjalmarson, 1991; fig. 27). Subdivision also should be considered where the width of the overflow area is at least five times the flow depth in the overflow area (fig. 27).

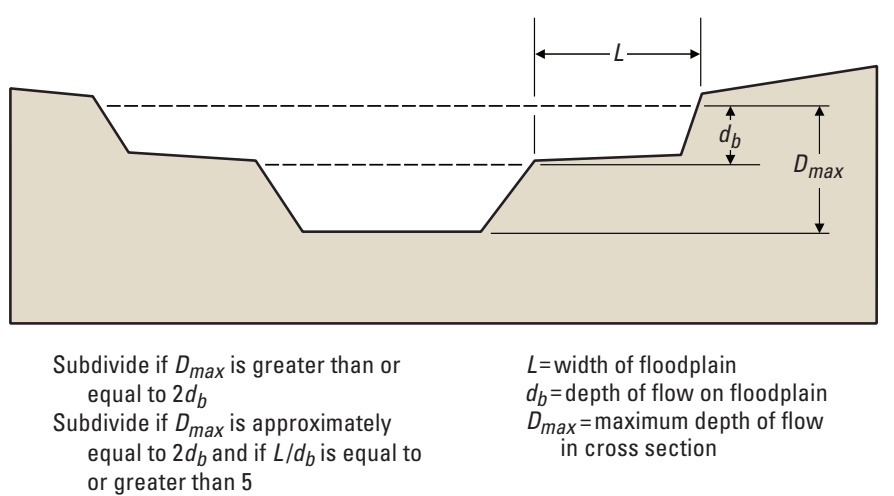

Figure 27. Subdivision criteria commonly used for streams in Maricopa County, Arizona. 
Davidian (1984) presents several examples illustrating the effects of improper subdivision. Figure 28 illustrates a cross section of a trapezoidal shaped channel having dense shrubs and trees on the banks; the section was subdivided near the bottom of each bank because of the abrupt change in roughness. A large percentage of the wetted perimeters $(P)$ of the triangular subareas $\left(A_{1}\right.$ and $\left.A_{3}\right)$ and possibly of the main channel $\left(A_{2}\right)$ are eliminated. A smaller wetted perimeter abnormally increases the hydraulic radius $(R=A / P)$, and this in turn results in a computed conveyance different from the conveyance determined for a section with a complete wetted perimeter. Conveyance $\left(K_{\mathrm{t}}\right)$ computed for the cross section in figure 28 would require a composite $n$ value of 0.034 . This is smaller than the $n$ values 0.035 and 0.100 that describe the roughness for the various parts of a basic trapezoidal shaped channel. The trapezoidal-shaped cross section in figure 28, therefore, should be left unsubdivided.

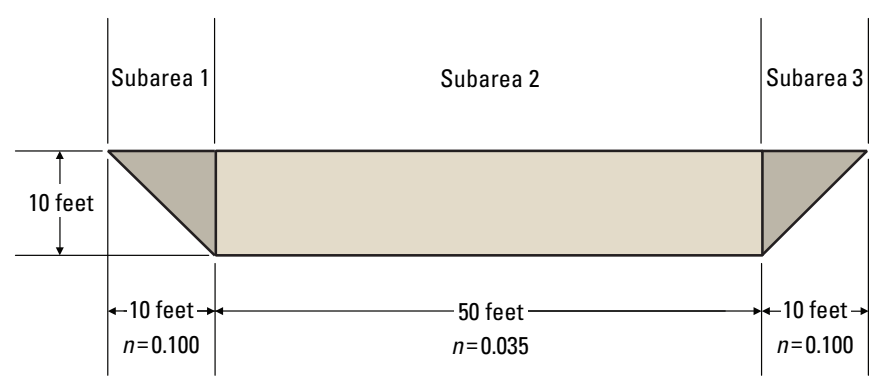

$$
\begin{aligned}
\text { Subdivided solution: } & \\
A_{1}=A_{3}=50 & A_{2}=500 \\
P_{1}=P_{3}=14.14 & P_{2}=50 \\
R_{1}=R_{3}=3.54 & R_{2}=10 \\
K_{1}=K_{3}=1,730 & K_{2}=98,500
\end{aligned}
$$

(1991) describe the major effect of vegetation on total roughness for streams in semi-arid to arid climates typical of the southwestern United States. For intermittent and ephemeral channels in these types of environments, vegetation may grow to substantial heights and densities in only a few years. Such growth throughout the main channels of natural and manmade streams can result in significant reduction in flow velocities and large increases in estimates of $n$ (Aldridge and Garrett, 1973; Thomsen and Hjalmarson, 1991; Phillips and others, 1998; Fischenich, 2000; table 3). In some cases, however, although the vegetation may appear substantial, peak flows during moderate to large flooding can be powerful enough to layover or remove weaker vegetation (Burkham, 1976; Phillips and Hjalmarson, 1994; Phillips and others, 1998). The flattened or removed vegetation may markedly decrease preflow estimates of $n$. Assuming the impact on vegetation occurs prior to peak flow, the decrease in $n$ would increase peak-flow channel conveyances. Increased conveyance effectively lowers peak-flow water-surface elevation compared with preflow simulations.

A study was conducted in central Arizona to better understand the relation between the power of flow, the changes in main-channel vegetation conditions, and the impact of the changes on computed water-surface elevations (Phillips and others, 1998). Flow and vegetation characteristics data were collected for development of a method to determine the impact of flow on vegetation conditions. Flow data included channel slope, channel cross-section geometry, and measured or computed discharge. Stream power was computed from these data (eq. 2). Vegetation characteristics or conditions, such as average height and density, were measured or estimated, described, and photographed before and after peak flows. A fundamental assumption needed to determine flow impact on vegetation conditions is that a critical stream power exists for specific vegetation conditions and that vegetation will bend or fracture when the critical stream power value is exceeded.

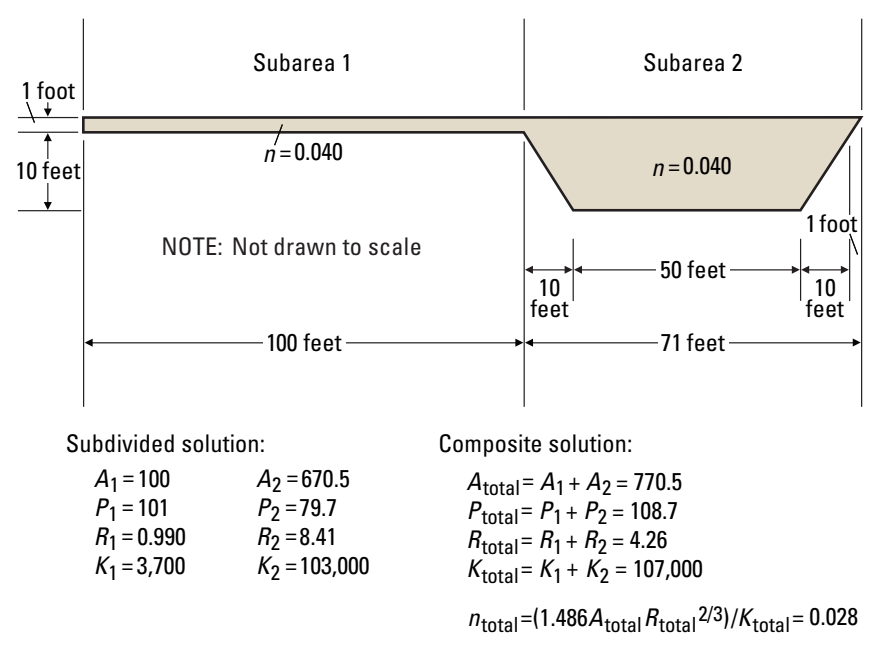

Figure 29. Effects of not subdividing a panhandle section.

\section{Suggested Procedures and Values For Selection of Manning's $n$ For Potentially Changing Vegetation Conditions}

Cowen (1956) indicated that channel vegetation can have the single greatest potential effect on the total roughness coefficient selected for a reach. Thomsen and Hjalmarson 
Adequately describing all the physical components that collectively characterize vegetation conditions in stream channels in central Arizona can be a complex and difficult task. Four vegetation characteristics were used to model the impact of flow on vegetation. The characteristics include the following: (1) flexural strength of the specific type and size of vegetation, (2) percent of flow blocked by the vegetation, (3) distribution of vegetation within the channel, and (4) depth of flow relative to the average vegetation height (Phillips and others, 1998).

The vegetation characteristics comprise a composite value called the vegetation-susceptibility index. The vegetation-susceptibility index is defined by

$$
K_{v}=V_{\text {flex }} C_{\text {blocking }} C_{\text {dist }} C_{\text {depth }}
$$

where,

$K_{v}=$ vegetation-susceptibility index, in foot-pounds,

$V_{\text {flex }}=$ vegetation-flexibility factor, in foot-pounds,

$C_{\text {blocking }}=$ vegetation-blocking coefficient,

$C_{\text {dist }}=$ vegetation-distribution coefficient, and

$C_{\text {depth }}=$ flow-depth coefficient.

The vegetation flexibility factor, $V_{\text {flex }}$, is considered the most significant factor in determining whether vegetation will bend or remain in a generally upright position when subjected to the power of flow. The unique physical properties of many types of vegetation enable them to bend to extreme angles when force is applied. The degree of bending generally varies for a given applied force. The force required to bend and lay over vegetation was quantified to obtain the flexural strength of different vegetation types (Phillips and others, 1998).

Dynamometers, which are mechanical instruments that measure the magnitude of tension in cables, were used to determine the force required to lay over four types of vegetation of varying size. The vegetation (saltcedar, willow, mesquite, and palo verde) ranged in height from 3 to 18 feet. Bending moments were determined by computing the product of the moment arm (distance from the base or pivot point to the location where the force was applied) and the force required to bend the vegetation to 45 degrees from vertical. Equations were developed from regression techniques of the bending moment with height for each of the four vegetation types (table 6).

Table 6. Regression equations relating bending moment to vegetation height for mesquite, palo verde, saltcedar, and willow.

[BM, bending moment, in foot-pounds; $\mathrm{H}$, height of vegetation, in feet]

\begin{tabular}{llc}
\hline $\begin{array}{c}\text { Vegetation } \\
\text { type }\end{array}$ & \multicolumn{1}{c}{ Equation } & $\begin{array}{c}\text { Coefficient of } \\
\text { Determination, } r^{2}\end{array}$ \\
\hline Mesquite & $\mathrm{BM}=10^{0.124 \mathrm{H}+0.935}$ & 0.88 \\
Palo verde & $\mathrm{BM}=10^{0.171 \mathrm{H}+0.848}$ & .86 \\
Saltceder & $\mathrm{BM}=10^{0.102 \mathrm{H}+0.880}$ & .87 \\
Willow & $\mathrm{BM}=10^{0.122 \mathrm{H}+0.581}$ & .98 \\
\hline
\end{tabular}

The bending moment (also referred to as flexural strength or stiffness) of the vegetation at varying heights can be estimated from the equations in table 6. For example, a flexural strength of $63.2 \mathrm{ft}-\mathrm{lb}$ is estimated for a 10-foot-tall willow, whereas a flexural strength of $361 \mathrm{ft}-\mathrm{lb}$ is estimated for a 10 -foot-tall palo verde. It is assumed that a lone palo verde in midchannel is substantially more likely to resist bending than a lone willow in midchannel when they are subjected to a similar magnitude of stream power and degree of submergence. Data acquired and analyzed during method development seem to support this conclusion (Phillips and others, 1998). For example, figure $30 \mathrm{~A}$ shows a lone willow about 15 feet tall that was laid over during a flow calculated at $6,590 \mathrm{ft}^{3} / \mathrm{s}$; figure $30 \mathrm{~B}$ shows a lone 16 -foot-tall palo verde that remained erect throughout a flow of $9,760 \mathrm{ft}^{3} / \mathrm{s}$. Depth of flow was about equal. The magnitude of the stream power that affected the palo verde was 20.2 (ft-lb/s)/ $\mathrm{ft}^{2}$ (table 6$)$. The magnitude of stream power to which the willow was subjected was equal to $12.9(\mathrm{ft}-\mathrm{lb} / \mathrm{s}) / \mathrm{ft}^{2}$ (table 6$)$. These data indicate that the large flexural strength of palo verde enabled it to resist a computed stream power that was substantially larger than the computed stream power that altered or laid over the willow with similar dimensions.

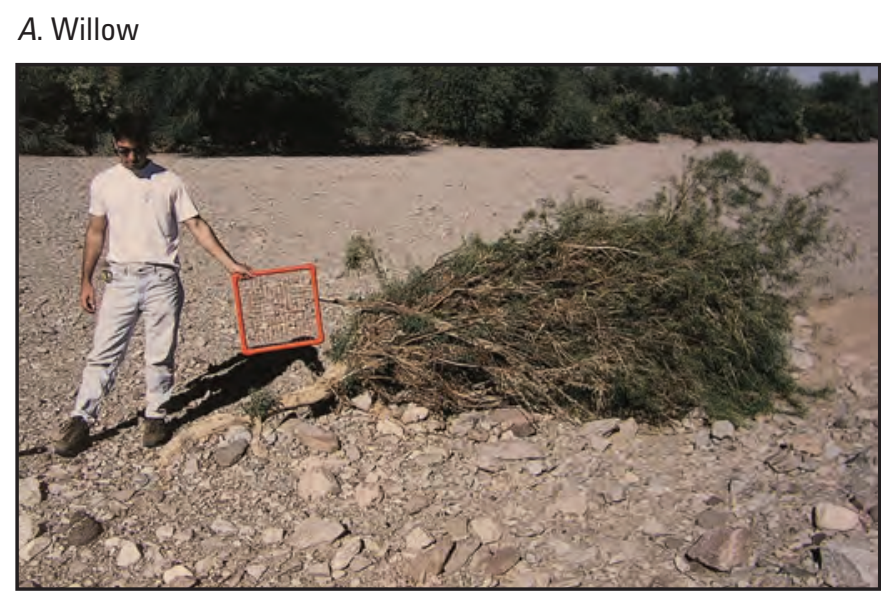

\section{B. Palo Verde}

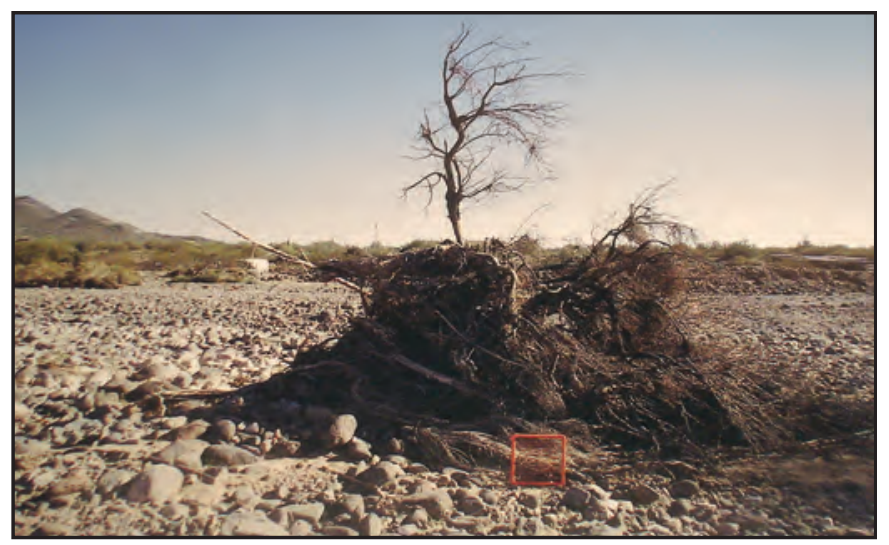

Figure 30. Impact of similar flows, or stream power, on different vegetation species of similar heights. $A$, Willow. $B$, Palo verde. 
A separate analysis of the flexural strength of arrowweed and other types of shrubs was not done. The flexural strength of shrubs studied during the investigation (Phillips and others, 1998) was assumed to be similar to that of willow. Other prevalent types of vegetation common in central Arizona, such as cottonwood and ironwood, were assumed to behave in a similar manner as willow and mesquite, respectively.

During the course of the study, the percent of the flow area blocked by vegetation was assumed to account for the combined resistant force associated with the vegetation (Phillips and others, 1998). The vegetation-blocking coefficient value, $C_{\text {blocking, }}$, was determined for each site by assigning a weighted value to the estimated percentage of the cross-section area of flow blocked by vegetation (table 7).

The spatial distribution of riparian vegetation in natural and constructed channels can substantially influence the effect of flow on the vegetation (Phillips and others, 1998). Vegetation aligned parallel to the direction of flow generally results from consistent base flow in a channel. Due to the combined resistant effect of the vegetation during high flow conditions, vegetation aligned parallel to flow can result in the redistribution of velocities across a channel section (fig. 31). The combined resistance causes a decrease in the velocities at the immediate location of the vegetation and may lessen the effect of flow on vegetation conditions. When vegetation is randomly distributed throughout a channel, velocity distribution is assumed to be fairly constant across a channel section. Vegetation-distribution coefficients $\left(C_{\text {diss }}\right)$ were, therefore, determined for vegetation aligned parallel to flow and for vegetation situated in a generally random manner throughout the main channel (table 8).

Table 7. Vegetation-blocking coefficients for selected areas of flow blocked by vegetation.

\begin{tabular}{cc}
$\begin{array}{c}{[<, \text { less than; }>\text {, greater than }]} \\
\begin{array}{c}\text { Area of flow blocked by vegeta- } \\
\text { tion, in percent }\end{array}\end{array}$ & $\begin{array}{c}\text { Vegetation-blocking coef- } \\
\text { ficient }\end{array}$ \\
\hline$<30$ & 1 \\
30 to 70 & 4 \\
$>70$ & 9 \\
\hline
\end{tabular}

Table 8. Vegetation-distribution coefficients for vegetation oriented to flow.

\begin{tabular}{lc}
\hline \multicolumn{1}{c}{ Orientation to flow } & $\begin{array}{c}\text { Vegetation-distribution coef- } \\
\text { ficient }\end{array}$ \\
\hline Parallel & 3 \\
Random & 1 \\
\hline
\end{tabular}

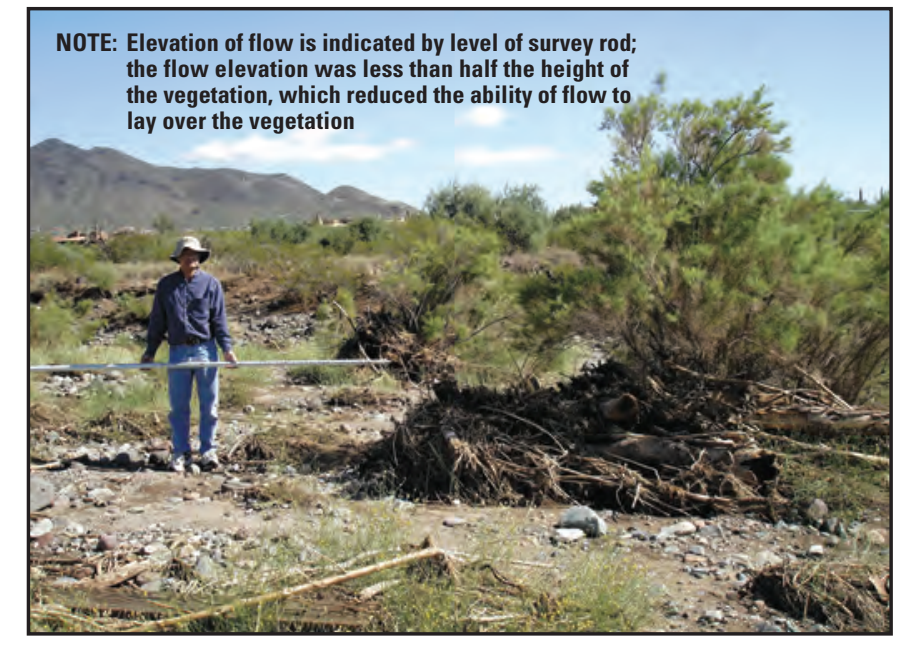

Figure 32. Vegetation that was affected little by flow. 
The trend indicates a relation exists between the vegetation-susceptibility index value and the magnitude of stream power (fig. 33). According to the relation, as computed vegetation-susceptibility indices increase, the stream power required to significantly impact and lay over the vegetation also increases. The trend line was defined as the vegetationsusceptibility threshold. In general, for stream power values that plot above this threshold, the vegetation can be expected to layover. For method use, the vegetation conditions and flow characteristics studied should be similar to the values used to develop the relationship (Phillips and others, 1998; fig. 33).
Table 9. Flow-depth coefficients for ratios of hydraulic radius to average vegetation height.

$[<$, less than; >, greater than]

\begin{tabular}{cc}
$\begin{array}{c}\text { Ratio of hydraulic radius to } \\
\text { average vegetation height }\end{array}$ & Flow-depth coefficient \\
\hline$<0.4$ & 60 \\
$.4-.6$ & 20 \\
$.7-.9$ & 5 \\
$1.0-1.5$ & 3 \\
$>1.5$ & 1 \\
\hline
\end{tabular}

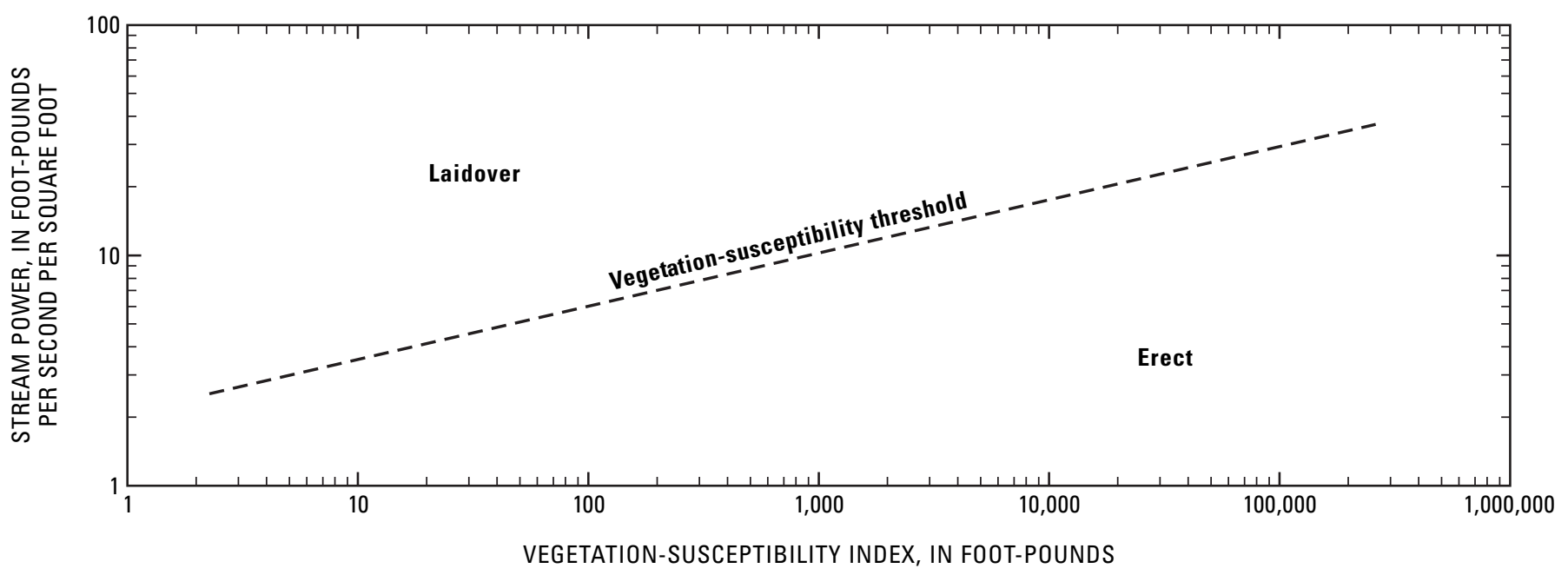

Figure 33. Relationship between stream power and a vegetation-susceptibility index for estimating the effect of flow on vegetation conditions.

\section{Suggested Procedure and Examples for Selection of Manning's $\boldsymbol{n}$ for Natural and Constructed Channels}

The procedure given in this section originally presented by Aldridge and Garrett (1973) involves a series of decisions that are based on the interaction of roughness elements. Decisions required to use the procedure can be difficult to explain in written material (Aldridge and Garrett, 1973). The procedure, therefore, is discussed by steps that are arranged to permit charting in logical order (fig. 34). After using the procedure a few times, the user may wish to combine steps or change the order of the steps. Experienced personnel may have the ability to perform the entire operation without the aid of the procedures, but the inexperienced user may find it useful. Steps outlined in figure 35 can be used as a guide for estimating flow impact on main-channel vegetation conditions.

Two example cases for determining total Manning's $n$ for a channel reach are provided at the end of this section. The example cases are for a specific design discharge that is confined within the banks of the channel. The hypothetical channel in example 1 consists of parallel bands of material, each of which has a different degree of roughness (figs. 36 and 37). The channel in example 2 consists of gravel and cobbles uniformly distributed in the channel (figs. 38 and 39). The channel also consists of randomly distributed shrubs. The stream power relation is employed to determine impact of flow on the vegetation conditions.

Step 1. Determine the channel type-stable channel, sand channel, or a combination of both - and whether the conditions would be representative of those that would exist during the design flow being considered. Look especially for possible high-water marks, bed movement, and excessive amounts of bank scour (from previous events). Attempt to visualize the conditions that would occur during the peak for the design discharge. Compare with other similar channels for which the roughness coefficient, $n$, has been verified or assigned by experienced personnel in order to estimate the possible range in $n$ values (Aldridge and Garrett, 1973; Thomsen and Hjalmarson, 1991; Phillips and Ingersoll, 1998). 
1. Determine channel type, and estimate conditions at time of flow event; compare the channel to other channels (both before and after flows) by using photographs and descriptions. If main-channel vegetation is present, utilize the stream power relationship to determine impact of peak flow on vegetation conditions (see fig 35 ).

2. Determine extent of reach to which the roughness factor will apply.

3. Determine how a base value(s) of $n$ will be assigned.

If a base value of $\boldsymbol{n}$ will be assigned for the entire channel, continue from here:

4. Determine the factors that will cause roughness and how each will be accounted for.

5. Step $\mathbf{5}$ is skipped when following this branch.

6. Determine type and size of bed material.

7. Assign a base $\boldsymbol{n}$ from tables, formulas, or comparison with other channels and verification photographs.

8-10. Steps 8 through 10 are skipped when following this branch.

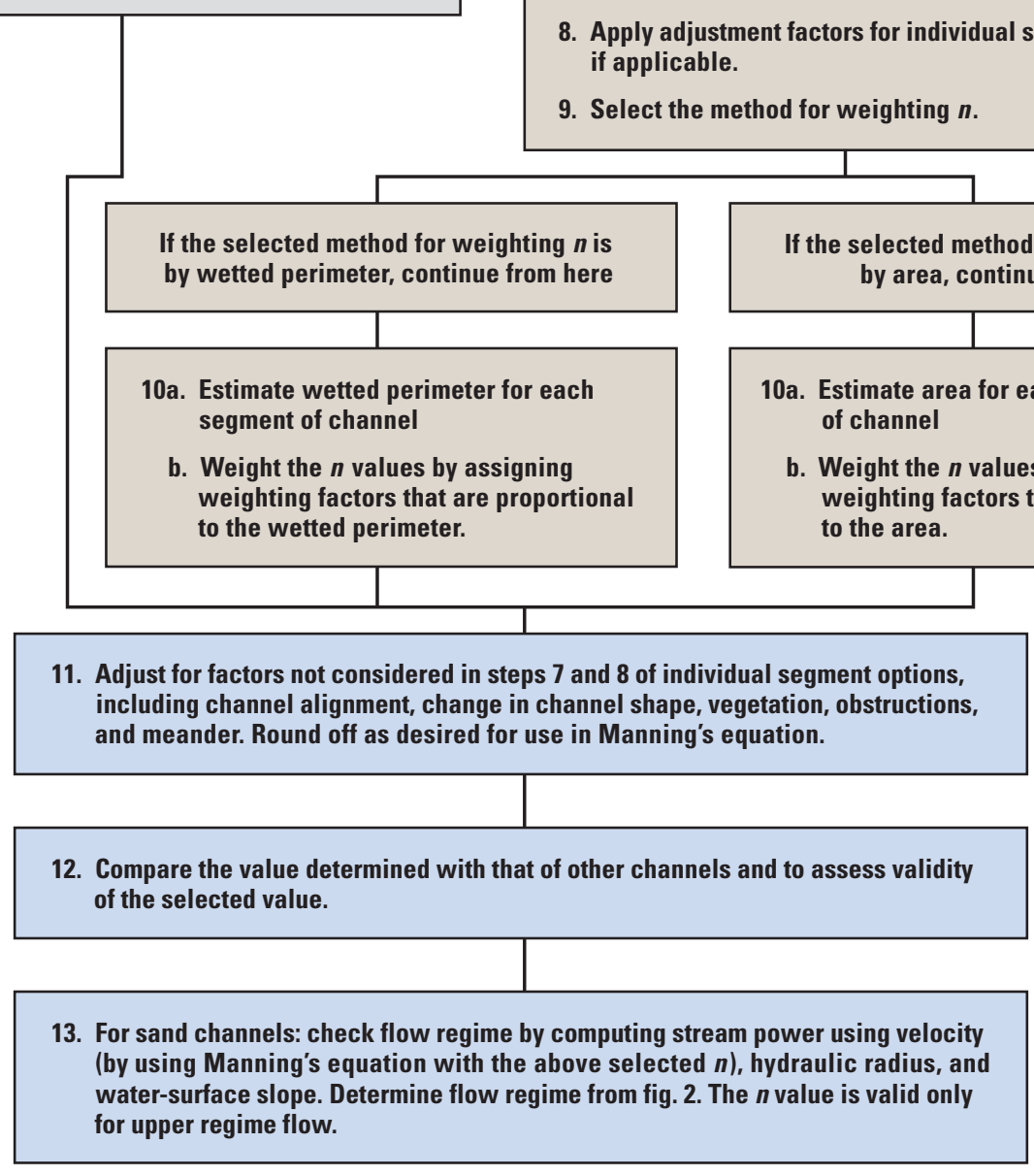

If base values for $\boldsymbol{n}$ will be assigned for individual segments of channel and used to derive a value of $n$ for the entire channel, continue from here:

4. Determine the factors that will cause roughness and how each will be accounted for.

5. Mentally divide channel into segments so that the roughness factor within a segment is fairly uniform.

6. Determine type and size of boundary material for each segment.

7. Assign a base $\boldsymbol{n}$ for each segment from tables, formulas, or comparison with other channels where Manning's $\boldsymbol{n}$ was verified.

Apply adjustment factors for individual segments

9. Select the method for weighting $n$. 
1a. Survey the channel to obtain parameters necessary for standardstep computations. In the estimation of roughness coefficients, fully weight the pre-flow vegetation characteristics for the selected discharge. (See fig. 34, step 1).

1b. Run standard-step computations using the surveyed channel parameters and selected roughness coefficients. From the computations, obtain average velocity, hydraulic radius, and water-surface slope for the selected cross section.

1c. By using the type and average height of vegetation in the selected cross section, estimate the vegetation-flexibility factor, $V_{\text {flex }}$, for each vegetation type using equations found in table 6.

\section{1}

1d. Determine the orientation of the vegetation (either oriented randomly or parallel to the flow), the percent cross-section area of flow blocked by vegetation, and the ratio of hydraulic radius to average vegetation height for the selected discharge. From this information, determine the values for the vegetationblocking coefficient, $C_{\text {blocking }}$ the vegetation-distribution coefficient, $\boldsymbol{C}_{\text {dist, }}$, and the flow-depth coeffient, $\boldsymbol{C}_{\text {depth }}$ (see tables 7 , 8, and 9).

1e. Compute stream power for the selected discharge.

1f. Compute the vegetation-susceptibility index for the selected discharge.

1g. Plot the values for the vegetation-susceptibility index and stream power for each type of vegetation present in the channel. If the values plot below the vegetation-susceptibility threshold, the vegetation probably will not be significantly altered by flow, and estimated values of $\boldsymbol{n}$ should be weighted accordingly. If the values plot above the vegetation-susceptibility threshold, the vegetation will be altered and possibly laid over. Use engineering judgment to estimate Manning's $\boldsymbol{n}$ values for the laid over vegetation.

Figure 35. Flow chart for estimating flow-induced changes to vegetation conditions.

In addition to visualizing conditions at peak flow, especially vegetation conditions, utilize the stream power and vegetation-susceptibility index relation described in the previous section to assist in determining flow impact on vegetation (fig. 35). Example case 2 at the end of this section illustrates the use of this method for estimating peak-flow vegetation conditions (figs. 38-40 and tables 10 and 11).
Step 2. Determine the extent of the reach to which the roughness factor will apply. Although $n$ may be applied to an individual cross section that is typical of a reach, it must account for the roughness in the reach of channel that encompasses the section (Thomsen and Hjalmarson, 1991). When two or more cross sections are being considered, the reach that encompasses any one section is considered to extend halfway to the next. For example, see figure 36 . In example 1, the $n$ value for section 2 represents the roughness in reach $B$. If the roughness is not uniform throughout the reach being considered, $n$ should be assigned for the average condition (Aldridge and Garrett, 1973).

Step 3. If the roughness is not uniform across the width of the channel, determine whether a base $n$ should be assigned to the entire cross section, or whether a composite $n$ should be developed by weighting values for individual segments of the channel having different amounts of roughness (Aldridge and Garrett, 1973; Jarrett, 1985; Thomsen and Hjalmarson, 1991). When the base value of $n$ is assigned to the entire cross section, the channel constitutes one segment being considered, and steps $5,8,9$, and 10 do not apply in such a case.

Step 4. Determine the factors or individual components that contribute to roughness and how each is to be taken into account. Particular factors may be dominant in a particular segment of the channel, or they may impact the flow for the entire cross section equally. The manner in which each factor is determined depends on how it combines with the other factors (Aldridge and Garrett, 1973). For example, a gently sloping bank may constitute a separate segment of the cross section; whereas, a vertical bank may add roughness either to the adjacent segment or the entire channel. Isolated boulders generally should be considered as obstructions (Aldridge and Garrett, 1973), but if boulders are scattered across the entire reach, it may be necessary to determine the median size of the bed material. Flow resistant vegetation growing in a distinct segment of channel may be assigned an $n$ value of its own (Aldridge and Garrett, 1973; Thomsen and Hjalmarson, 1991); whereas energy loss caused by vegetation growing on or along steep banks or scattered along the channel bottom will be accounted for by using an adjustment factor that can be applied either to a segment of the channel or to the entire cross section (Aldridge and Garrett, 1973; Phillips and Ingersoll, 1998). Parts of the channel that have dense vegetation and vegetation downstream from projections of banks may be areas of dead water or backwater areas. The backwater areas can be eliminated from the cross section, however, the Manning's $n$ value for the adjacent segment should be sufficiently high to account for roughness along the streamward side of the brush. If a composite $n$ is derived from segments, the user should continue to step 5. For all other instances, step 5 is omitted from the procedure. 


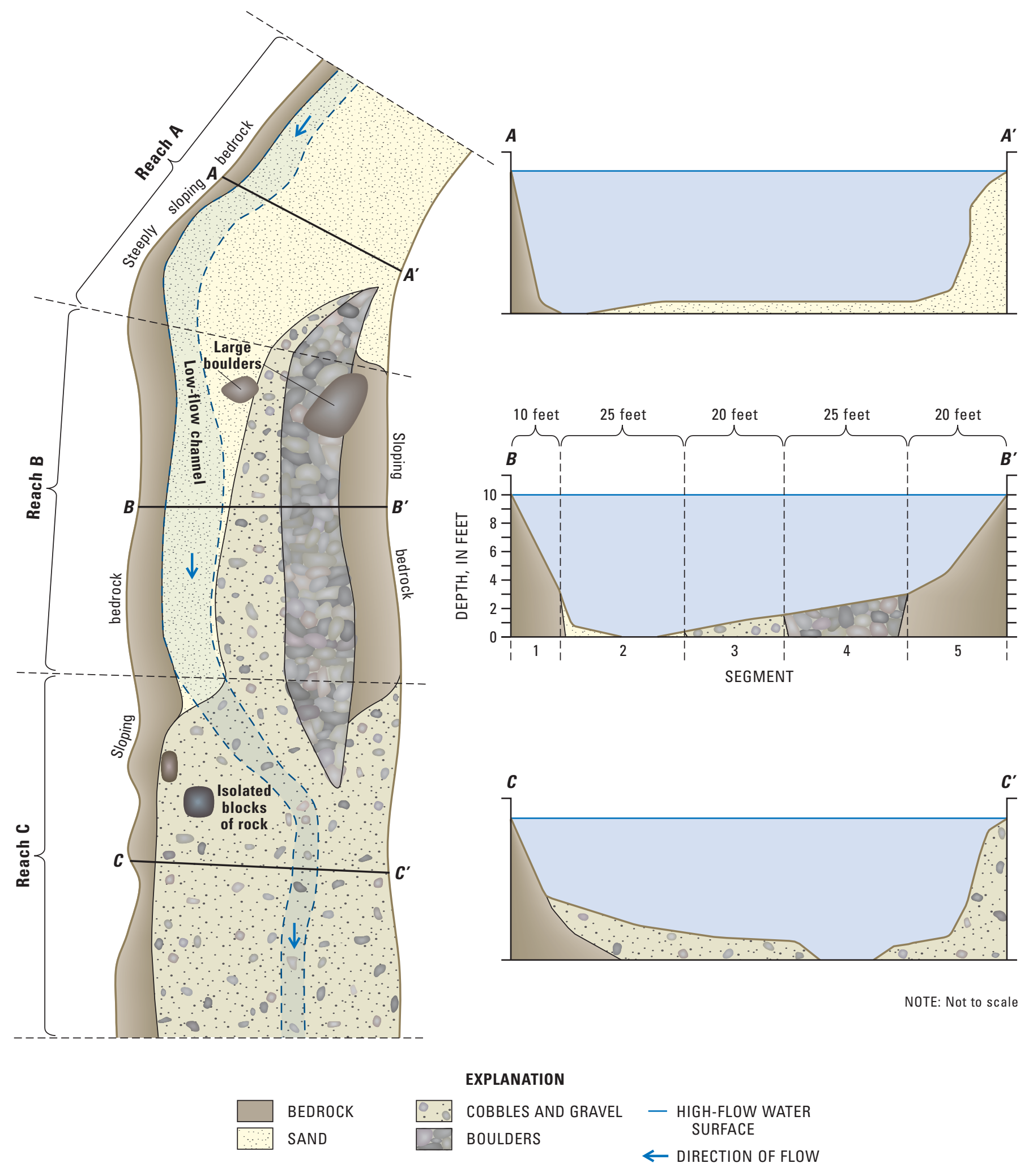

Figure 36. Diagram of hypothetical channel showing reaches and segments used in assigning $n$ values. 
1: Computation of Manning's $n$

Stream and location: See fig. 36

Reach or section: Sections 1-3; example for section 2, reach B

Event or design for which $\boldsymbol{n}$ is assigned: Flood Insurance Study for the 100-year design discharge

1. Describe channel (if needed draw sketch on back of sheet): Reach $B$ has a low-water sand channel bounded

by bedrock on one side and a sloping bar of gravel, cobbles, and boulders on the other. Section should

be divided into segments - (1) bedrock, (2) sand, (3) gravel and cobble 1 to 6 inches in diameter,

and (4) boulders 1 to 3 feet in diameter.

Does the use of the stream power relation indicate the vegetation (shrubs) will be laid over or remain in a relatively upright position (use flow chart in fig. $\mathbf{3 5}$ and information in the previous section)? The stream-power relation is not utilized as no vegetation is present in the channel.

2. Are present conditions representative of those during flood? Manning's $n$ value assigned for present conditions as no past flood information is available for this site.

3. Is roughness uniformly distributed across the channel? No If no, on what basis should $\boldsymbol{n}$ for individual segments be weighted? By wetted perimeter

4. How will the roughness producing effects of the following roughness components be accounted for?

Bank roughness: Bedrock bank will be used as a separate segment

Bedrock outcrops: Not applicable

Isolated boulders: Add adjustment for 2 large boulders at start of reach

Bank roughness: Bedrock bank will be used as a separate segment

Vegetation: Not applicable

Obstructions: Not applicable

Meander: Not applicable

5-10. Computation of weighted Manning's $n$ :

\begin{tabular}{|c|c|c|c|c|c|c|c|c|c|c|}
\hline \multirow{2}{*}{$\begin{array}{c}\text { Segment } \\
\text { number and } \\
\text { and material }\end{array}$} & \multicolumn{2}{|c|}{$\begin{array}{c}\text { Approximate } \\
\text { dimensions (feet) }\end{array}$} & \multirow{2}{*}{$\begin{array}{c}\text { Wetted } \\
\text { perimeter } \\
\text { (feet) }\end{array}$} & \multirow{2}{*}{$\begin{array}{c}\text { Area } \\
\text { (square-feet) }\end{array}$} & \multirow{2}{*}{$\begin{array}{l}\text { Median } \\
\text { grain size } \\
\text { (inches) }\end{array}$} & \multirow{2}{*}{$\begin{array}{c}\text { Base } n \\
\text { for } \\
\text { segment }\end{array}$} & \multirow[b]{2}{*}{ Adjustments } & \multirow[b]{2}{*}{ Adjusted $n$} & \multirow{2}{*}{$\begin{array}{l}\text { Weight } \\
\text { factor }\end{array}$} & \multirow{2}{*}{$\begin{array}{c}\text { Adjusted } n \\
\text { X weight } \\
\text { factor }\end{array}$} \\
\hline & Width & Depth & & & & & & & & \\
\hline (1) Bedrock & 10 & $0-7$ & 20 & & - & 0.045 & - & 0.045 & 0.12 & 0.0054 \\
\hline (2) Sand & 25 & $7-9$ & 43 & & $0.8 \mathrm{~mm} \quad(\mathbf{1} / \mathbf{3 2})$ & .025 & - & .025 & .25 & .0062 \\
\hline (3) Gravel & 20 & $9-8$ & 37 & & 6 & .035 & - & .035 & .22 & .0077 \\
\hline (4) Boulders & 25 & $8-7$ & 40 & & 24 & .050 & - & .050 & .23 & .0115 \\
\hline (5) Bedrock & 20 & $7-0$ & 30 & & - & .045 & - & .045 & .18 & .0081 \\
\hline & & & \multirow[t]{2}{*}{ Sum $=$} & & & & & & $\begin{array}{c}\text { Sum }= \\
1.00\end{array}$ & $\begin{array}{l}\text { Sum }= \\
0.0389\end{array}$ \\
\hline & & & & & & & & & \multicolumn{2}{|c|}{ Weighted $\boldsymbol{n}=0.039$} \\
\hline
\end{tabular}

11. Adjustments:

\begin{tabular}{|c|c|c|}
\hline Factor & Describe conditions briefly & Adjustment \\
\hline Banks & Included above & - \\
\hline Channel alignment (curves and bends) & Bend in reach A causes some turbulance & +0.002 \\
\hline Changes in shape & Channel has a fairly uniform shape within reach $B$ & 0 \\
\hline Obstructions & 2 large boulders at upstream end of reach-add roughness & +0.002 \\
\hline Vegetation & Not used & 0 \\
\hline Meander & Multiply by: - & Add: - \\
\hline \multicolumn{3}{|l|}{ Other } \\
\hline & & $\begin{array}{l}\text { Weighted } \boldsymbol{n}+\text { added } \\
\text { adjustments }=0.043\end{array}$ \\
\hline & & Use $n=0.043$ \\
\hline
\end{tabular}

Figure 37. Example for computing Manning's $n$ value. 

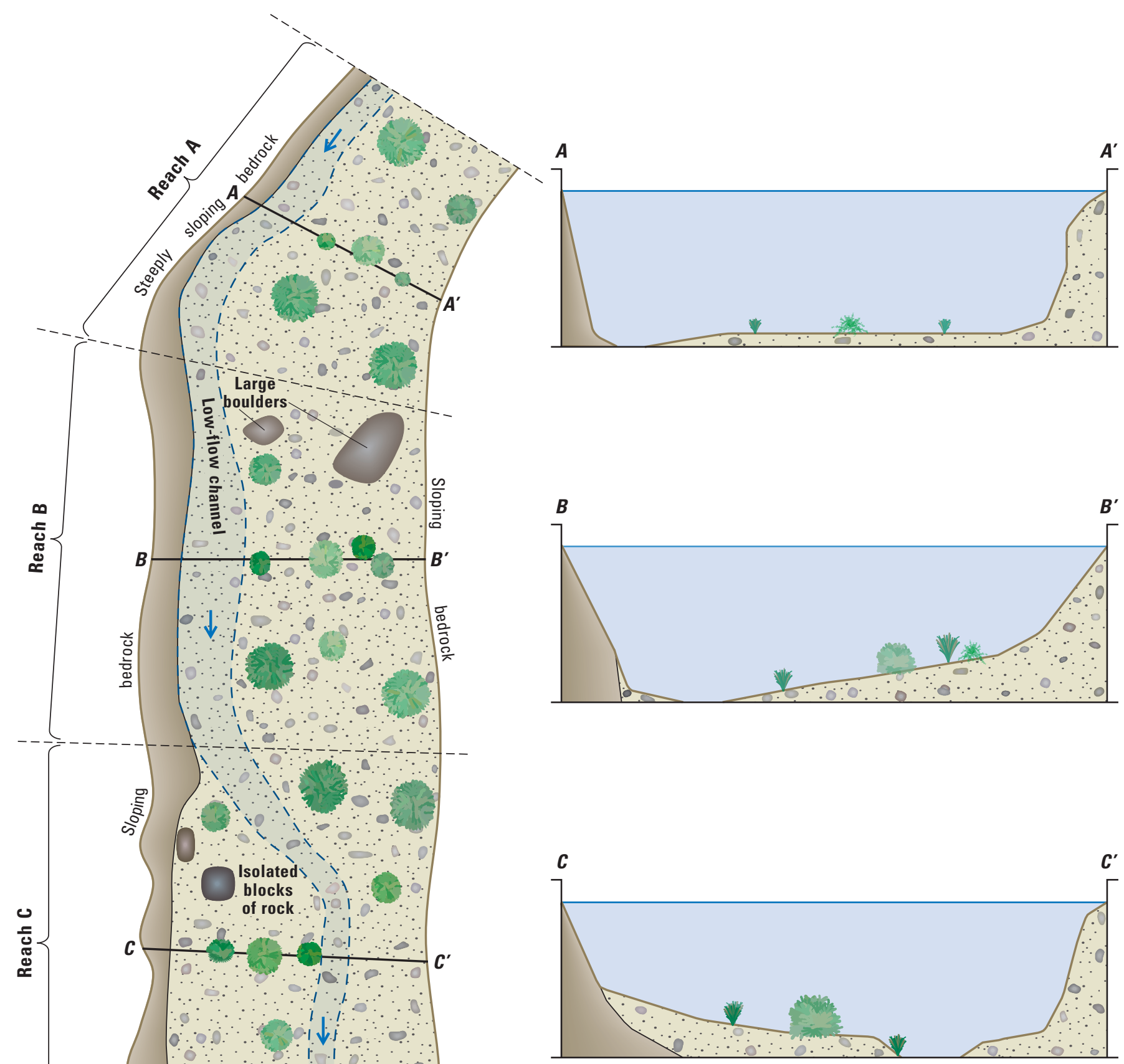

EXPLANATION

BEDROCK

GRAVEL AND COBBLES
- HIGH-FLOW WATER SURFACE

$\leftarrow$ DIRECTION OF FLOW

Figure 38. Diagram of hypothetical channel showing reaches used in assigning $n$ values. 
2: Computation of Manning's $n$

Stream and location: See fig. 38

Reach or section: Sections 1-3; example for section 2, reach B

Event or design for which $\boldsymbol{n}$ is assigned: Flood Insurance Study for $\mathbf{1 0 0}$-year design discharge

5. Describe channel (if needed draw sketch on back of sheet): Reach B has a low-water channel bounded by bedrock on one side and a sloping bar of cobbles on the other. Shrubs grow randomly throughout the channel. Flow depth is almost 2 times the height of the shrubs.

Does the use of the stream power relation indicate the vegetation (brush) will be laid over or remain in a relatively upright position (use flow chart in fig. $\mathbf{3 5}$ and information in the previous section)? Use of stream power relation indicates all the shrubs will be laid over as a result of the power of flow (see tables $\mathbf{1 0}$ and $\mathbf{1 1}$ and fig. 40).

6. Are present conditions representative of those during flood? The shrubs were probably laid over during flow.

7. Is roughness uniformly distributed across the channel? Yes If no, on what basis should $\boldsymbol{n}$ for individual segments be weighted? $N / A$

8. How will the roughness producing effects of the following roughness components be accounted for?

Bank roughness: Bedrock bank will be added under "adjustments"

Bedrock outcrops: Not applicable

Isolated boulders: Add adjustment for 2 large boulders at start of reach

Vegetation: Shrubs are randomly distributed in the channel

Obstructions: Not applicable unless mats of shrubs catch on the boulders

Meander: Not applicable

5-10. Computation of weighted Manning's $n$ :

\begin{tabular}{|c|c|c|c|c|c|c|c|c|c|c|}
\hline \multirow{2}{*}{$\begin{array}{c}\text { Segment } \\
\text { number and } \\
\text { and material }\end{array}$} & \multicolumn{2}{|c|}{$\begin{array}{c}\text { Approximate } \\
\text { dimensions (feet) }\end{array}$} & \multirow{2}{*}{$\begin{array}{c}\text { Wetted } \\
\text { perimeter } \\
\text { (feet) }\end{array}$} & \multirow{2}{*}{$\begin{array}{c}\text { Area, in } \\
\text { square } \\
\text { (feet) }\end{array}$} & \multirow{2}{*}{$\begin{array}{c}\text { Median } \\
\text { grain size } \\
\text { (inches) }\end{array}$} & \multirow{2}{*}{$\begin{array}{c}\text { Base } n \\
\quad \text { for } \\
\text { segment }\end{array}$} & \multirow[b]{2}{*}{ Adjustments } & \multirow[b]{2}{*}{ Adjusted $n$} & \multirow{2}{*}{$\begin{array}{l}\text { Weight } \\
\text { factor }\end{array}$} & \multirow{2}{*}{$\begin{array}{c}\text { Adjusted } n \\
\text { X weight } \\
\text { factor }\end{array}$} \\
\hline & Width & Depth & & & & & & & & \\
\hline & & & & & & & & & & \\
\hline & & & & & & & & & & \\
\hline & & & & & & & & & & \\
\hline & & & & & & & & & & \\
\hline & & & & & & & & & & \\
\hline & & & Sum $=$ & & & & & & Sum $=$ & Sum $=$ \\
\hline & & & & & & & & & Weight & $n=$ \\
\hline
\end{tabular}

11. Adjustments:

\begin{tabular}{|c|c|c|}
\hline Factor & Describe conditions briefly & Adjustment \\
\hline Banks and bed & Right bank is fairly smooth bedrock, similar in roughness to cobbles. $d_{50}$ cobbles $=6^{\prime \prime}$ & +0.035 \\
\hline Channel alignment (curves and bends) & Bend in reach $A$ causes some turbulance & +0.002 \\
\hline Changes in shape & Channel has a fairly uniform shape within reach $B$ & 0 \\
\hline Obstructions & 2 large boulders at upstream end of reach-add roughness & +0.002 \\
\hline Vegetation & Stream power relation indicated vegetation impact on energy losses will be negligible & 0 \\
\hline Meander & \begin{tabular}{l|l} 
Not used & Multiply by: - \\
\end{tabular} & Add: - \\
\hline \multicolumn{3}{|l|}{ Other } \\
\hline & & $\begin{array}{l}\text { Weighted } n+\text { added } \\
\text { adjustments }=0.039\end{array}$ \\
\hline & & Use $n=0.039$ \\
\hline
\end{tabular}

Figure 39. Example for computing Manning's $n$ value. 


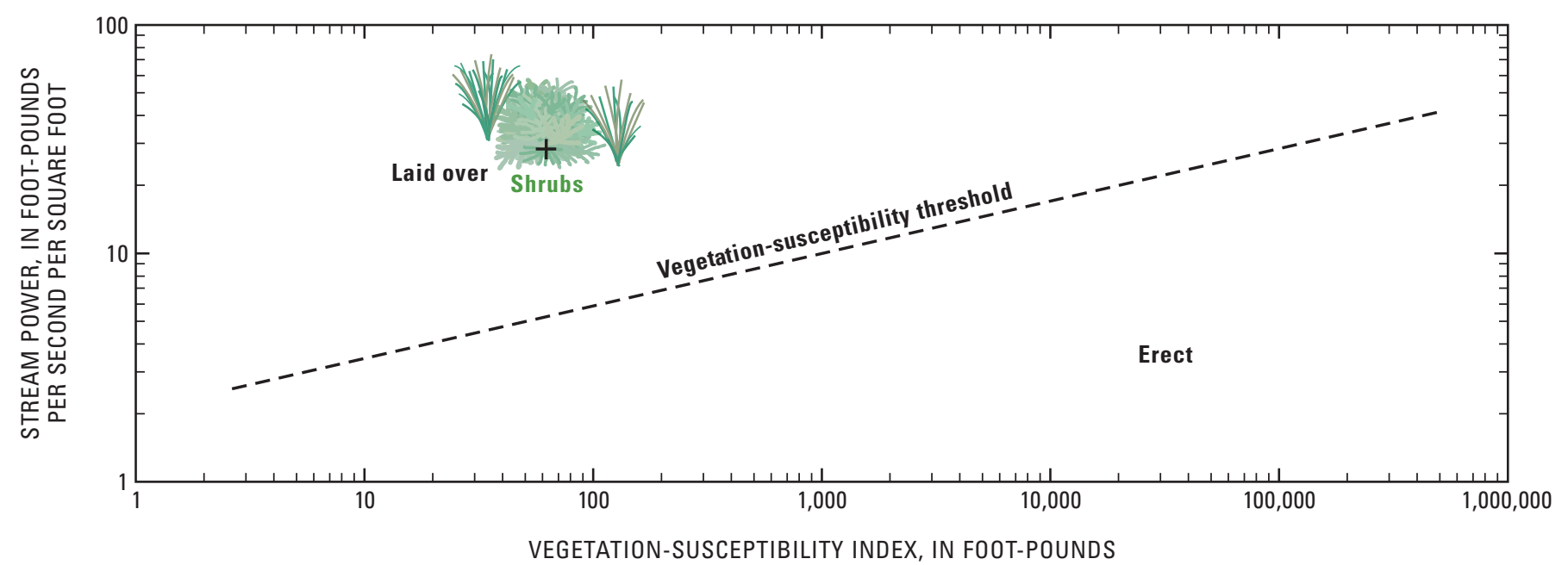

Figure 40. Impact of computed stream power on the vegetation-susceptibility index for shrubs.

Table 10. Vegetation characteristics, coefficients, and vegetation susceptibility index for shrubs.

\begin{tabular}{|c|c|c|c|c|c|c|c|c|}
\hline $\begin{array}{c}\text { Vegetation } \\
\text { type }\end{array}$ & $\begin{array}{c}\text { Average veg- } \\
\text { etation height, } \\
\text { in feet }\end{array}$ & $\begin{array}{l}\text { Vegetation- } \\
\text { flexibility fac- } \\
\text { tor, } V_{\text {flex }} \text { (ft-lb) }\end{array}$ & $\begin{array}{l}\text { Flow blocked } \\
\text { by vegetation } \\
\text { (percent) }\end{array}$ & $\begin{array}{c}\text { Vegetation- } \\
\text { blocking } \\
\text { coefficient, } \\
C_{\text {blocking }} \\
\end{array}$ & $\begin{array}{c}\text { Vegetation } \\
\text { distributed } \\
\text { randomly or } \\
\text { parallel to flow }\end{array}$ & $\begin{array}{c}\text { Vegetation- } \\
\text { distribution } \\
\text { coefficient, } \\
C_{\text {dist }} \\
\end{array}$ & $\begin{array}{l}\text { Ratio of hydraulic } \\
\text { radius to average } \\
\text { vegetation height }\end{array}$ & $\begin{array}{c}\text { Flow-depth } \\
\text { coefficient, } \\
C_{\text {depth }} \\
\end{array}$ \\
\hline \multicolumn{9}{|c|}{ Vegetation-susceptibility index, $K_{v}=\left(V_{\text {flex }} C_{\text {blocking }} C_{\text {dist }} C_{\text {depth }}\right) \mathrm{ft}-\mathrm{lb}=62.0 \mathrm{ft}-\mathrm{lb}$ (shrubs) } \\
\hline
\end{tabular}

Table 11. Hydraulic parameters used to compute stream power.

$\left[(\mathrm{ft}-\mathrm{lb} / \mathrm{s}) / \mathrm{ft}^{2}\right.$, foot-pounds per square foot $]$

\begin{tabular}{cccc}
\hline $\begin{array}{c}\text { Specific weight of } \\
\text { water, in pounds } \\
\text { per cubic foot }\end{array}$ & $\begin{array}{c}\text { Hydraulic } \\
\text { radius }(R), \\
\text { in feet }\end{array}$ & $\begin{array}{c}\text { Water-surface } \\
\text { slope }\left(S_{w}\right) \text {, in } \\
\text { feet per foot }\end{array}$ & $\begin{array}{c}\text { Mean velocity }(V), \\
\text { in feet per second }\end{array}$ \\
\hline 62.4 & 8 & 0.006 & 9.5 \\
\hline
\end{tabular}

Step 5. Divide the channel width into segments according to general roughness (Jarrett, 1985; Thomsen and Hjalmarson, 1991). If distinct parallel bands of bed material of different particle sizes or of different roughness are present, use of segments can facilitate defining the contact between the different types of material (fig. 36). The dividing line between any two segments should parallel the general flow lines in the stream and should be located to represent the average contact between the differing types of material (Thomsen and Hjalmarson, 1991). The dividing line must extend through the entire reach, as defined in step 2, even if one of the different types of bed material may not be present throughout the entire reach. If a segment contains more than one type of roughness, it may be necessary to use an average size of bed material, which would apply in figure 36 if the sand in segment 3 extended further downstream and the gravel and cobbles started closer to section 1. Figure 36 shows two distinct segments in reach B having material in the gravelto boulder-size range. In the field, however, material of this size usually grades from fine-grained material at the edge of the sand channel to boulders near the shrub or vegetation line. In both instances, segments 3 and 4 should be combined as one segment. Where sand is mixed with gravel, cobbles, and boulders throughout a channel, it may be impractical to divide the main channel (Aldridge and Garrett, 1973).

Step 6. Determine the type of material that occupies each segment of channel, and determine the median particle size in each segment.

If the particles can be separated by size by screening, small samples of the bed material should be collected at 8 to 12 sites in the segment of the reach (Aldridge and Garrett, 1973). The samples are combined and the composite sample for the particular segment is passed through screens that divide the sample into a minimum of five size ranges. The volume or weight of material in each size range is measured and converted to a percentage of the total. The size or weight that corresponds to the $50^{\text {th }}$ percentile is obtained from a distribution curve developed by plotting particle size versus the percentage of the size smaller than that indicated (Phillips and Ingersoll, 1998).

If the material is too large to be screened, the median size of a random sample of the bed material in the segment is measured (Thomsen and Hjalmarson, 1991; Phillips and Ingersoll, 1998). Approximately 100 cobbles or boulders are sampled. For determination of $d_{50}$, particle diameter equals that of 50 percent of the particles. 
Experienced personnel generally can make a fairly accurate estimate of the median particle size by inspection of the channel bed material if the range in particle size is small (Aldridge and Garrett, 1973).

Step 7. Determine the base value of $n$ for each segment of channel using tables 1 or 2 , equations 3 or 4 , the comparisons made in step 1 , or a combination of these. If a composite $n$ value is derived from segments, the user should proceed to step 8. If $n$ is assigned for the channel as a whole, the user should go to step 11 .

Step 8. Add adjustment factors from table 3 that contribute to energy loss; these factors apply only to individual segments of the channel.

Step 9. Select the basis for weighting $n$ for the channel segments. Wetted perimeter should be used for trapezoidal and U-shaped channels that have banks composed of one material and the channel bed composed of another. Wetted perimeter also should be used where the depth across the channel is fairly uniform. Weighting $n$ for channel segments by area should be used where the depth varies considerably or where dense shrubs or trees occupy a large and distinct part of the channel (Aldridge and Garrett, 1973; Thomsen and Hjalmarson, 1991).

Step 10. Estimate the wetted perimeter or area for each segment and assign a weighting factor for each segment that is proportional to the total wetted perimeter or area. Multiply the $n$ for each segment by its weighting factor, and divide the sum of the products by the sum of the weighting factors (fig. 37) (Thomsen and Hjalmarson, 1991).

Step 11. Select the adjustment factors from table 3 for conditions that influence $n$ for the entire channel. Do not include adjustment factors for any items used in steps 7 and 8 , and consider upstream conditions that may cause a disturbance in the study reach (Aldridge and Garrett, 1973). Add the adjustment factors to the weighted $n$ from step 10 to derive the overall $n$ for the reach being considered. When a multiplying factor for a meander is required, it is applied only after the other adjustments have been added to the base $n$. Repeat steps 3 through 11 for each additional reach when more than one reach is used for the hydraulic computations.

Step 12. Compare the $n$ values computed for the study reach with $n$ values estimated and verified for other channels (as discussed in step 1) to determine if the final values of $n$ obtained in step 11 appear reasonable.

Step 13. Check the flow regime for all sand channels. Use the $n$ value from step 11 and the Manning equation to compute velocity (eq. 1). Velocity, hydraulic radius, and water-surface slope are then used to compute stream power. The flow regime is determined by utilizing information in figure 2.

\section{Vegetation Maintenance Plan Guidelines}

Vegetation has the ability to grow to significant heights and densities in a matter of a few years, and stream power may not be sufficient to alter vegetation in some stream channels. Homes and businesses have been built directly adjacent to some of these vegetated channels. If substantial amounts of mature vegetation are not included in $n$-value estimates in the initial design of the channel, then the vegetation may result in decreased channel conveyance and flood waters overtopping channel banks when design flows do occur.

In the past, vegetation may have been removed completely to ensure adequate conveyance of floodflows. In recent years, however, emphasis has shifted toward preservation of riparian vegetation that can provide habitat for wildlife, as well as aesthetically pleasing, multiuse areas for homeowners and businesses.

An engineering-based approach was used to develop vegetation-maintenance guidelines with the primary objective of optimizing the preservation of riparian habitat and to provide aesthetically pleasing multiuse areas for homeowners, while mitigating damage from floodflows along stream channels. The new guidelines described in subsequent sections of this document can be used as a tool for maintenance of vegetation and for development of vegetated channels. The new guidelines were developed for hydrologists, engineers, conservationists, and developers. To ensure that the guidelines are as robust as possible with respect to engineering design, the procedures used to develop these guidelines were based on a series of decisions that focus on selected values of Manning's $n$. Tables and photographs presented earlier in this report were used as the primary resource for selection of these roughness coefficients. Several case examples are presented at the end of this section, which should provide the user with a better understanding of the procedures defined in the guidelines.

\section{Freeboard}

Freeboard can be defined as an additional amount of conveyance area measured by using height above a flood level. The purpose of freeboard is to mitigate risk by providing a factor of safety. The flood level considered is normally the design water-surface elevation computed for the design discharge, or the Base Flood Elevation (BFE) used for Flood Insurance Studies (FIS). The design water-surface elevation is used to describe both situations. For the purposes of example cases 2,3 , and 4 at the end of this section, the minimum amount of freeboard required above the design water-surface elevation is 1 foot. An alternate vegetation-maintenance process is illustrated in example case 1, in which freeboard is not considered. Channel banks are not levied in any of the example cases.

The importance of maintaining the minimum factor of safety is significant; therefore, vegetation management and maintenance plans should adhere to maintaining the minimum 
required freeboard. Vegetation can grow quickly, which can cause channel conveyance to decrease and freeboard, or the factor of safety, to diminish or be consumed completely. This is the primary purpose for making periodic inspections of vegetation conditions.

Ideally, for stream channels with newly computed BFEs and void of all vegetation, Manning's $n$ values are adjusted according to the amount of vegetation anticipated for future conditions (table 3). For example, a newly constructed channel that has a firm earth base and concrete banks requires assessment of current roughness factors, including those for future vegetation conditions. If a Manning's $n$ value of 0.030 is selected for a channel void of vegetation, and it would be desirable to allow mesquite to grow to a density of approximately 1 tree per 100 feet of channel; the adjusted vegetation component may be in the range of 0.025 to 0.050 . The vegetation conditions and corresponding $n$ value should not increase above the design value, or freeboard, may be partially or completely lost.

For channels that were originally designed under no-vegetation conditions and for which future-vegetation conditions were not taken into account, only flexible grasses and other types of vegetation determined to layover during design flows should be allowed to grow within the channel. Any vegetation that may decrease velocity, and consequently increase design flow area, should be considered for removal from the channel.

\section{Examples of Guideline Use}

Stream channels that are addressed in the example cases include trapezoidal-shaped channels for which the original design is for zero-vegetation influences on $n$, and current and future-vegetation conditions are included in the original design.

Alternate vegetation-thinning criteria developed prior to methods developed and described in this document are used in example case 1 . The alternate criteria are used to illustrate the need to address Manning's $n$ value and freeboard when maintaining vegetation and developing vegetation-maintenance plans. The vegetation-maintenance plans presented in example cases 2, 3, and 4 use thinning criteria on the basis of Manning's $n$ and freeboard according to guidelines suggested in this document.

\section{Example case 1}

The use of, and the rationale for, the new guidelines can be illustrated by examining alternative vegetation-maintenance activities in a constructed channel (fig. $41 A$ and $B$ ). The constructed flood-control channel originally was designed for no or very sparse vegetation conditions. Subsequently, however, growths of mesquite, palo verde, and shrubs such as desert broom have grown to large spatial densities and to heights that surpass the flood-channel banks (fig. 41A). Owing to a growing concern that channel conveyance has been reduced and flood banks could be overtopped by the design discharge, local representatives determined that vegetation in the wash needed to be maintained or thinned (fig. 41B). By using thinning criteria that was primarily based on tree height and trunk diameter, shrubs and smaller palo verde and mesquite were removed and lower branches on the remaining palo verde and mesquite trees were trimmed to allow for greater channel conveyance. USGS staff, by using information acquired before and after maintenance, determined the roughness coefficients for five surveyed cross sections of the channel (table 12). Manning's $n$ values were selected for initial, pre- and post-vegetation conditions on the basis of information contained in table 3. The U.S. Army Corps of Engineers Hydrologic Engineering Centers River Analysis System (HECRAS) was used to simulate water-surface elevations for the channel under the various vegetation conditions. The step-backwater computer simulations were run by using the design discharge, the channel geometry from the surveyed sections, and the selected roughness coefficients (fig. 42A, $B$, and $C$ ). When the channel was originally designed, it appears there would have been adequate freeboard (fig. 42A). Simulation results using HECRAS, however, indicate that the design discharge for the channel for full-grown vegetation conditions would overtop channel banks and flood adjacent areas (fig. 42B). Velocities would be slowed significantly compared to initial channel conditions and cross-section area would compensate with a rise in water-surface elevations by an average of 3.92 feet (table 12). Simulations conducted for post-vegetation maintenance conditions indicate that the design discharge would remain within most of the channel. Because of the thinning criteria, many large trees were left within the reach from sections 3 to 5 . The remaining cluster or clump of trees resulted in selection of larger roughness coefficients for this area of the study reach. Consequently, the design discharge overtopped the right channel bank at sections 4 and 5 (fig. $42 \mathrm{C}$ ). Additionally, the simulated water surface removed all conveyance that should have been available for freeboard. Use of the guidelines in this report would have resulted in more vegetation being removed, lower roughness coefficients, and larger conveyance, allowing design flow to remain below required freeboard levels. 


\section{A. Before maintenance}

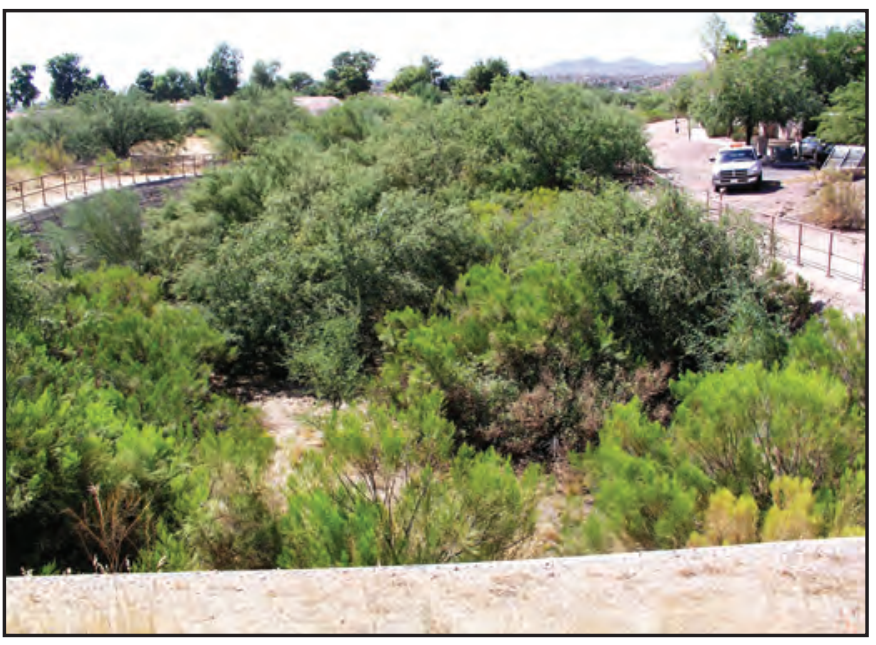

B. After maintenance

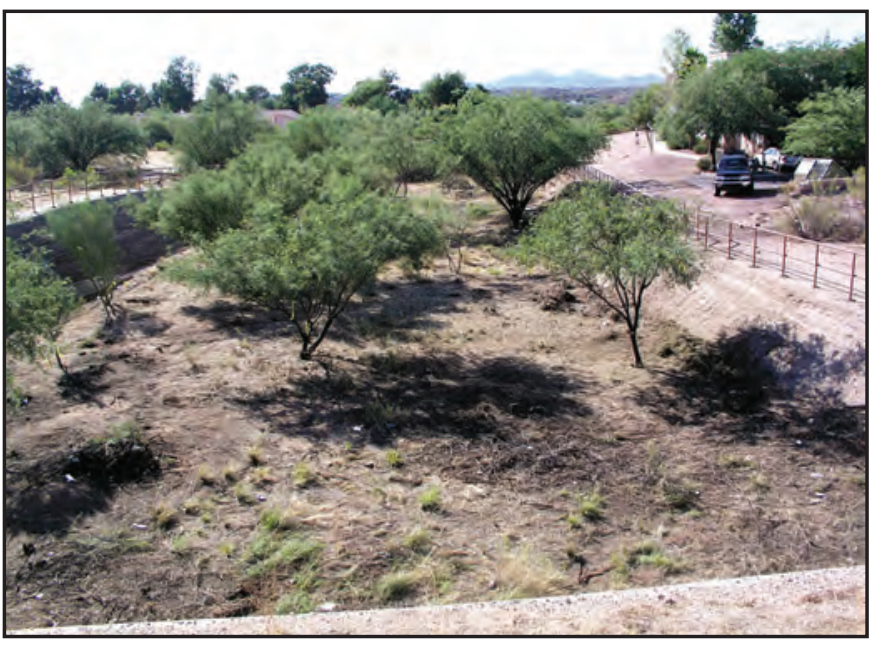

Figure 41. Constructed channel that required vegetation modification. $A$, Before maintenance of vegetation, July 28, 2005. $B$, after maintenance of vegetation, August 3, 2005.
Table 12. Hydraulic properties of flow for the constructed channel in example case 1. Velocity, area, and water-surface elevations were computed by using estimated Manning's $n$ values and a design discharge.

[See figure 42 for sections and simulated water-surface elevations. $\mathrm{ft}$, feet; ft/s, feet per second; $\mathrm{ft}^{2}$, square feet]

\begin{tabular}{ccccc}
\hline $\begin{array}{c}\text { Cross } \\
\begin{array}{c}\text { Section } \\
\text { no. }\end{array}\end{array}$ & $\begin{array}{c}\text { Manning's } \boldsymbol{n} \\
\text { value }\end{array}$ & $\begin{array}{c}\text { Velocity } \\
(\mathbf{f t} / \mathbf{s})\end{array}$ & $\begin{array}{c}\text { Area } \\
\left(\mathbf{f t}^{2}\right)\end{array}$ & $\begin{array}{c}\text { Water-surface el- } \\
\text { evation, arbitrary } \\
\text { datum (ft) }\end{array}$ \\
\hline \multicolumn{5}{c}{ Initial conditions (void of vegetation) } \\
\hline 1 & 0.028 & 11.86 & 320 & 13.00 \\
2 & .028 & 9.56 & 325 & 14.20 \\
3 & .028 & 10.80 & 367 & 14.29 \\
4 & .028 & 12.17 & 325 & 14.62 \\
5 & .028 & 12.37 & 320 & 15.88 \\
\hline
\end{tabular}

\begin{tabular}{ccccc}
\multicolumn{4}{c}{ Pre-vegetation maintenance conditions (vegetation fully grown) } \\
\hline 1 & .080 & 7.12 & 557 & 16.00 \\
2 & .080 & 6.41 & 617 & 16.90 \\
3 & .100 & 6.35 & 623 & 17.80 \\
4 & .150 & 5.81 & 681 & 19.46 \\
5 & .150 & 5.53 & 716 & 21.41
\end{tabular}

\begin{tabular}{lcccc}
\hline \multicolumn{5}{c}{ Post-vegetation maintenance conditions } \\
\hline 1 & .035 & 9.76 & 406 & 14.00 \\
2 & .035 & 8.81 & 450 & 14.67 \\
3 & .040 & 9.30 & 426 & 15.04 \\
4 & .050 & 9.21 & 430 & 15.87 \\
5 & .060 & 9.61 & 412 & 17.07
\end{tabular}


A. Simulated water-surface elevations for initial channel conditions.

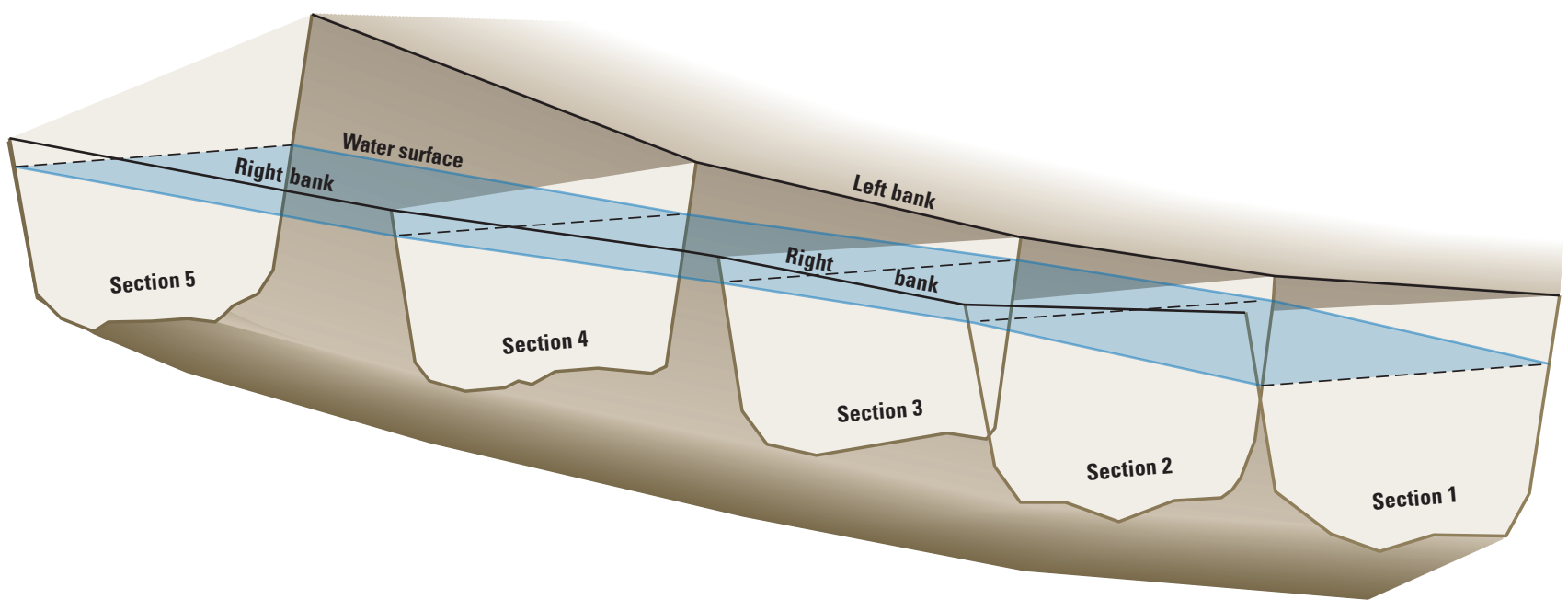

B. Simulated water-surface elevations for fully-grown vegetation conditions.

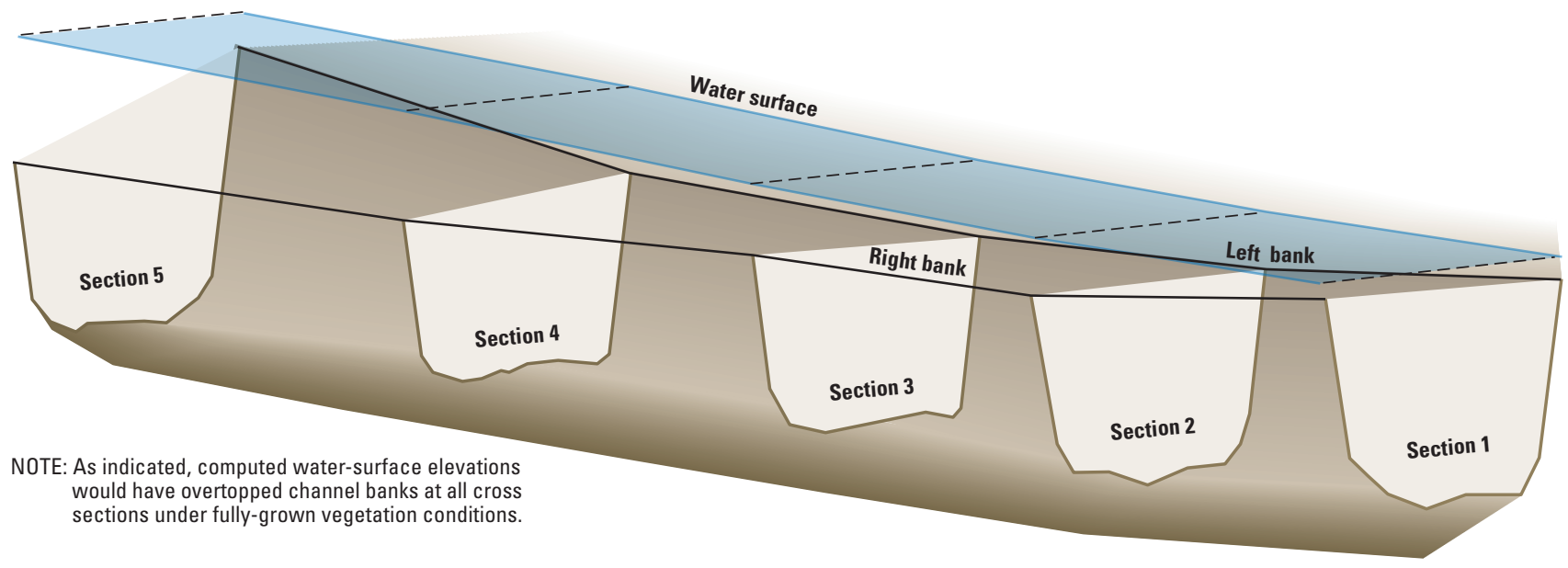

C. Simulated water-surface elevations for post-vegetation maintenance conditions

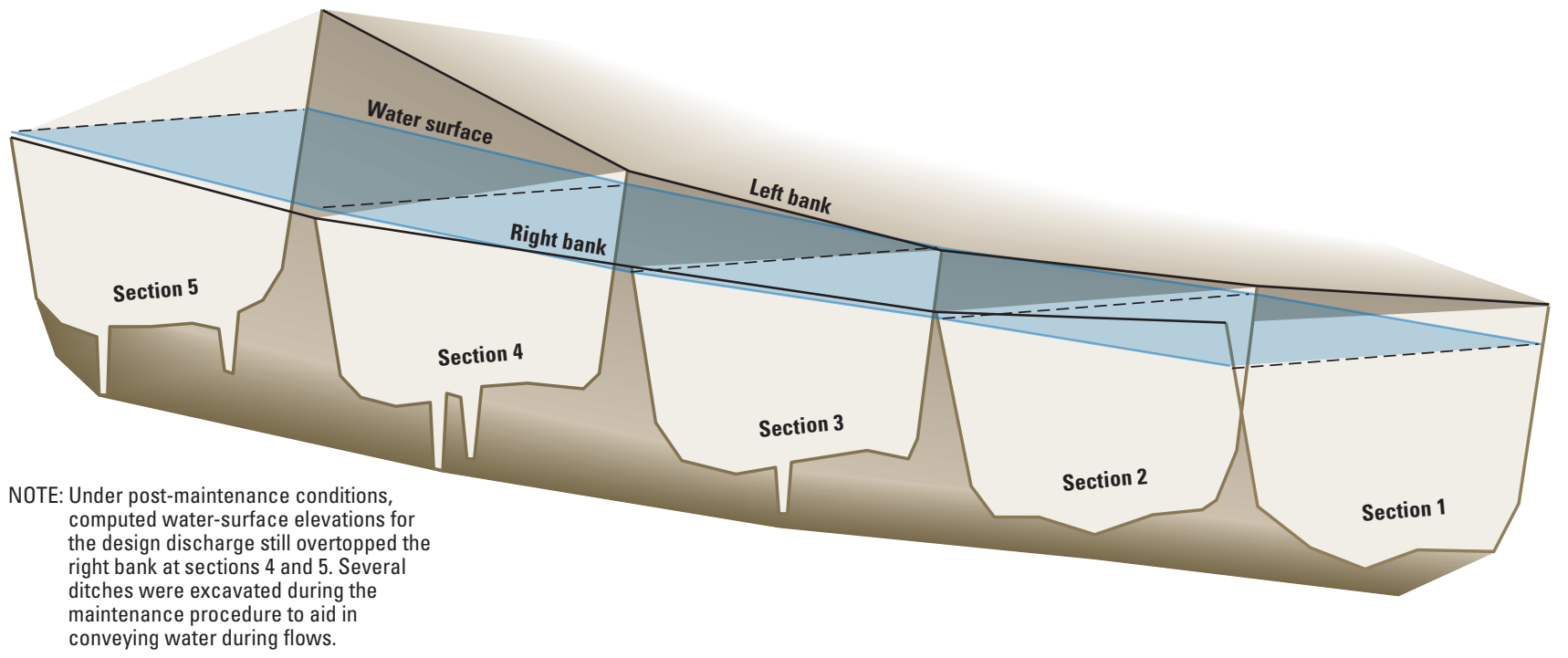

Figure 42. Simulated water-surface elevations for the constructed channel in example case 1. $A$, Initial channel conditions. $B$, Fullygrown vegetation conditions. $C$, Post-vegetation maintenance conditions. 


\section{Example case 2}

For example case 2, consider a constructed trapezoidalshaped channel that originally was void of any vegetation. The initial Manning's $n$ value selected was 0.030 and an additional 0.015 was estimated for future conditions when vegetation is anticipated to grow in the bed of the channel. An $n$-value of 0.045 was used for the final design computations, allowing 1 foot of additional conveyance or freeboard. A vegetation maintenance plan was established on completion of the channel. Over the next 10 years, however, the vegetation assessment and maintenance plan was neglected and forgotten. After 10 years, mesquite rooted in the channel substrate and grew to a height that averaged 16 feet, surpassing the height of the channel banks. Furthermore, shrubs took root that averaged about 5 feet in height. The average amount of mesquite that blocks flow is approximately 60 percent, and the approximate amount of shrubs that blocks flow is 20 percent. According to information in table 3, Manning's $n$ for the design flow increased from the initial composite value of 0.045 to a range of 0.100 to 0.200 (average 0.150 ). According to standard-step simulations, the channel no longer has adequate conveyance to carry the design flow, thus freeboard will be lost and banks will be overtopped when a design flow occurs (fig. $43 A$ and $B$ ).

It would seem that significant thinning of the vegetation is now warranted. Before any maintenance activities are engaged, however, the stream power relation should be utilized to determine if the design flow has the power to lay over the shrubs and possibly the mesquite.

Values acquired in the field needed to compute the vegetation-susceptibility index for the shrubs and mesquite are given in table 13. Hydraulic values acquired from the HECRAS simulations for peak design flow were used for the stream-power computations (table 14). The resultant values for each vegetation type are then plotted with corresponding stream power (fig. 44). As indicated, although shrubs plot close to the threshold, both shrub and mesquite need to be considered for thinning to decrease the Manning's $n$ value for the vegetation component back to its original value of 0.015 (or a composite $n$ value of 0.045 ).

For this example case, the Manning's $n$-value for the vegetation component should be no more than 0.015 , which allows for a select amount of shrubs and trees to remain in the channel (table 3 ). There are many vegetation maintenance schemes or scenarios that could be developed to meet the criteria for freeboard. For example case 2, however, only two vegetation-maintenance scenarios are presented. For scenario 1 , native vegetation was left randomly distributed to diminish the potential additive effect of the sphere of influence for turbulence on flow caused by the vegetation (fig. 45; table 3 ). Scenario 1 may be more aesthetically pleasing to local residents (fig. 46). For scenario 2, native mesquite trees and some shrubs would be clumped where possible (fig. 47).
Clumping the vegetation may present a better habitat environment for wildlife (fig. 48). The aditive strength of clumped vegetation will make it much more resistant to flow and, therefore, could be a good method for protecting vegetation from the power of flow. The trees for scenario 2 should be arranged or maintained so that there is one clump per three cross section lengths of channel to ensure spheres of influence do not overlap (fig. 47). These procedures should allow the vegetation component of Manning's $\mathrm{n}$ to be approximately 0.015 for this constructed channel (table 3 ).

A new maintenance plan should be enacted that includes periodic inspection or assessment of vegetation conditions. Maintenance of vegetation should be conducted if deemed necessary.

\section{Example Case 3}

The vegetation-maintenance plan considered in example case 3 is for a gravel- and cobble-bed, straight uniform channel that recently had experienced a high-flow event. Following the event, a few palo verde trees in the channel remained in an upright position, and had fairly significant amounts of debris on the upstream side. Shrubs were evident in the reach prior to the flow (fig. 49), but laidover and/or removed during the event (fig. 50). The area adjacent to this channel (right and left banks) was designated for a new housing and business development. A FIS was conducted prior to development. A base Manning's $n$ value of 0.033 was selected for the cobble substrate (fig. 50). The vegetation component of Manning's $n$ selected for the few standing palo verde trees was selected to be 0.020 (fig. 51). No vegetation-component addition was made to account for future growth of shrubs or other vegetation, and no other components of $n$ were believed to contribute to energy losses within the channel. Total composite n, therefore, for the hydraulic computations was 0.053. The FIS indicated that the previous flow event approximated a statistical 25-year flow. A 100-year design flow was determined, and the BFE was computed with 1 foot of freeboard (fig. 52). Within 1 year of completion of the FIS, homes and business were constructed adjacent to the channel.

After a 5-year period, no additional trees grew in the channel; however, shrubs grew throughout the channel to a density greater than about 70 percent and heights averaging 5 feet (fig. 53). Because the originally selected $n$ value of 0.053 did not account for future growth of vegetation in the channel, and homes and business were constructed immediately adjacent the channel, there was concern the channel may no longer be capable of conveying the design discharge (fig. 54). Vegetation maintenance was considered; however, first the streampower relation was used to determine if the shrubs would be fully laidover on the rising limb of the 100-year design flood hydrograph. 
A. Original design computed water-surface elevation

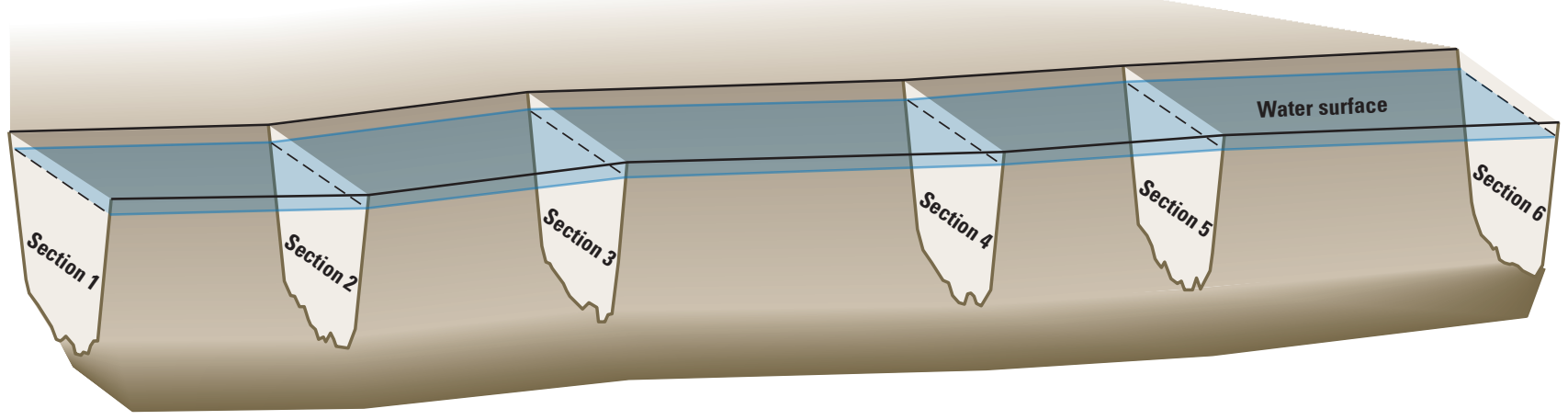

$B$. Water-surface elevation for a fully vegetated channel

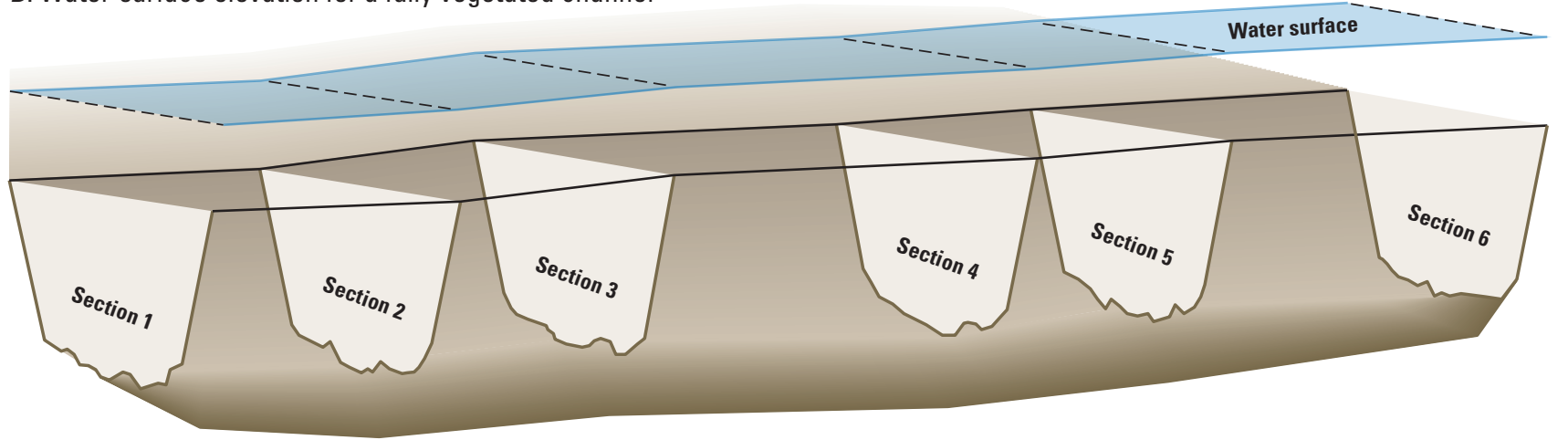

Figure 43. HECRAS standard-step computer simulations for the constructed channel in example case 2. $A$, Original design computed water-surface elevation for $n=0.045$ (base $n$ value $=0.030$ and future vegetation $n$-value component of 0.015 ). $B$, Water-surface elevation for a fully vegetated channel at an average $n=0.150$.

Table 13. Vegetation characteristics, coefficients, and vegetation-susceptibility index for shrubs and mesquite for example case 2.

[ft-lb, foot-pound]

\begin{tabular}{|c|c|c|c|c|c|c|c|c|}
\hline $\begin{array}{c}\text { Vegetation } \\
\text { type }\end{array}$ & $\begin{array}{l}\text { Average veg- } \\
\text { etation height, } \\
\text { in feet }\end{array}$ & $\begin{array}{l}\text { Vegetation- } \\
\text { flexibility fac- } \\
\text { tor, } V_{\text {flex }} \text { (ft-lb) }\end{array}$ & $\begin{array}{c}\text { Flow blocked } \\
\text { by vegetation } \\
\text { (percent) }\end{array}$ & $\begin{array}{c}\text { Vegetation- } \\
\text { blocking } \\
\text { coefficient, } \\
C_{\text {blocking }} \\
\end{array}$ & $\begin{array}{l}\text { Vegetation } \\
\text { distributed } \\
\text { randomly or } \\
\text { parallel to flow }\end{array}$ & $\begin{array}{c}\text { Vegetation- } \\
\text { distribution } \\
\text { coefficient, } \\
C_{\text {dist }} \\
\end{array}$ & $\begin{array}{l}\text { Ratio of hydraulic } \\
\text { radius to average } \\
\text { vegetation height }\end{array}$ & $\begin{array}{c}\text { Flow-depth } \\
\text { coefficient, } \\
C_{\text {depth }} \\
\end{array}$ \\
\hline mesquite & 16 & 830 & $30-70$ & 4 & Randomly & 1 & 0.4 & 20 \\
\hline
\end{tabular}

Vegetation-susceptibility index, $K_{v}=\left(V_{\text {flex }} C_{\text {blocking }} C_{\text {dist }} C_{\text {depth }}\right)=46.5 \mathrm{ft}$-lb (shrubs) and 66,400 ft-lb (mesquite)

Table 14. Hydraulic parameters used to compute stream power for example case $2 .$.

$\left[\mathrm{ft}-\mathrm{lb} / \mathrm{s} / \mathrm{ft}^{2}\right.$, foot-pounds per second per square foot $]$

\begin{tabular}{|c|c|c|c|}
\hline $\begin{array}{l}\text { Specific weight of water, in } \\
\text { pounds per cubic foot }\end{array}$ & Hydraulic radius $(R)$, in feet & $\begin{array}{l}\text { Water-surface slope }\left(S_{w}\right) \text {, in feet } \\
\text { per foot }\end{array}$ & $\begin{array}{l}\text { Mean velocity }(U) \text {, in feet per } \\
\text { second }\end{array}$ \\
\hline 62.4 & 6 & 0.003 & 3 \\
\hline
\end{tabular}




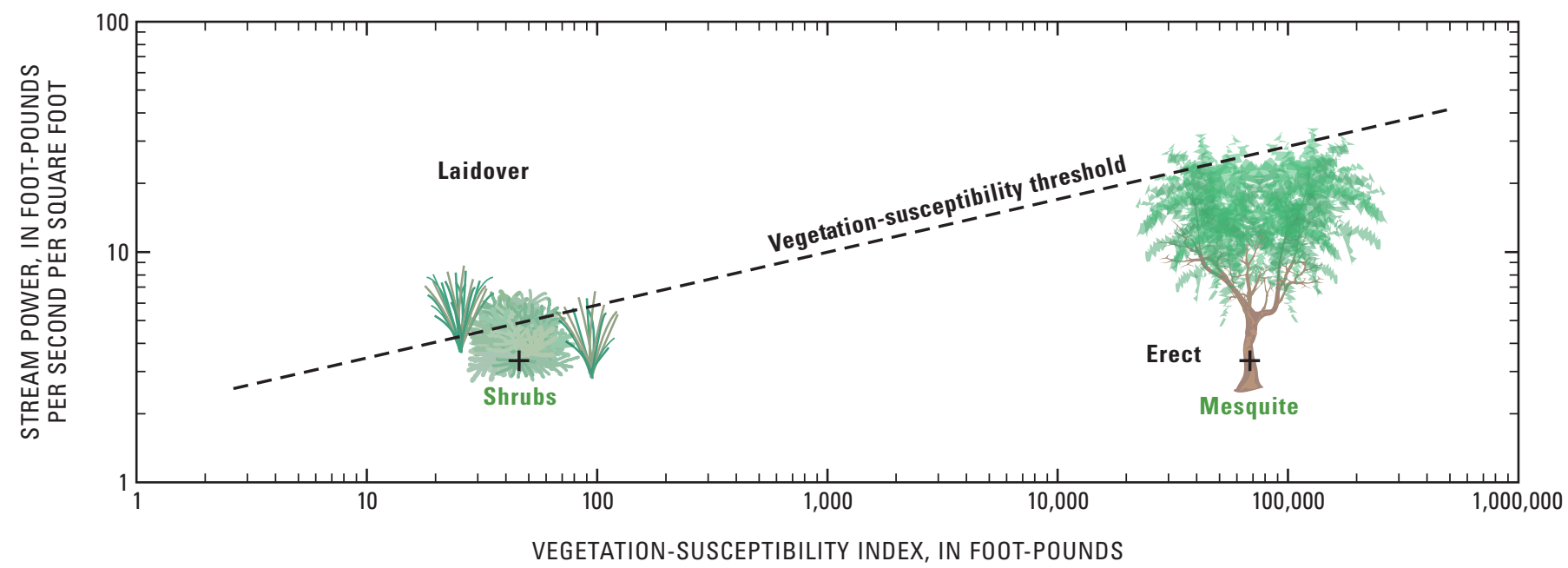

Figure 44. Impact of computed stream power on the vegetation-susceptibility index for shrubs and mesquite for example case 2.

From standard-step computations made after the 5year period, and a Manning's $n$ value for present conditions (selected to be 0.083 ), values were acquired for computation of stream power. For shrubs and palo verde averaging 5 and 16 feet in height, respectively, the vegetation flexibility factor is 15.5 and $3,848 \mathrm{ft}-\mathrm{lbs}$, respectively. The percent of flow blocked by the shrubs is estimated to be greater than 70 percent, while the palo verde is estimated at less than 30 percent. The vegetation blocking coefficients, therefore, are 9.0 for shrubs and 1.0 for palo verde. The palo verde and shrubs are randomly distributed in the main channel. The vegetation distribution coefficient, therefore, is 1.0 for palo verde and shrubs. From the standard-step computations, hydraulic radius is equal to 3.6 feet. The flow-depth ratio, therefore, is 0.7 and 0.2 for shrubs and palo verde, respectively. Hence, the flowdepth coefficient is 5.0 and 60 , respectively. The vegetationsusceptibility index is 698 for the shrubs, and 231,000 ft-lbs for the palo verde (tables 15 and 16).

Subsequently, stream power was computed and plotted with the vegetation-susceptibility indices for the shrub and palo verde (fig. 55). According to their plotting positions, the shrubs would be laidover on the rising limb of the 100 -year flow hydrograph. Thus, the roughness component that represents the shrub can be considered negligible and not be added to the composite $n$ value. The palo verde, however, probably would remain in an upright position. The impact of the palo verde on total roughness was included in the original FIS when the BFE was determined. It was determined that it should not be maintained. For this example case, the guidelines indicate that shrubs also should not be maintained, and a vegetation assessment and maintenance plan should be enacted to periodically document any noticeable future changes in vegetation conditions.

\section{Example Case 4}

The vegetation-maintenance plan considered in case 4 is for a planned residential community that is built adjacent to a gravel- and grass-lined channel. A low-flow channel was constructed, which winds through the bottom of the main channel in this multiuse area. Small mesquite trees were planted along the side of the low-flow channel to a density of about 2 to 3 trees per cross-section length of reach (fig. $56 A$ and $B$ ). Current and future conditions for the planted mesquite trees were considered in the selection of the vegetation component of Manning's $n$ for the FIS. A base $n$ value of 0.027 was selected for the gravel- and grass-lined channel; the vegetation component selected for the mesquite for present conditions was 0.015. An estimated 0.025 was added to the component for the mesquite to account for future growth (table 3 ). The total composite $n$-value for the design discharge for the FIS, therefore, was 0.077. A freeboard of 1 foot was added to the BFE, and the homes were subsequently constructed. The original engineers and developers initiated a vegetation assessment and maintenance plan to ensure that roughness coefficients would not exceed the design $n$-value of 0.077 . The assessment plan, however, was neglected, and after 5 years many additional mesquite trees had taken root. 
A. Originally designed channel

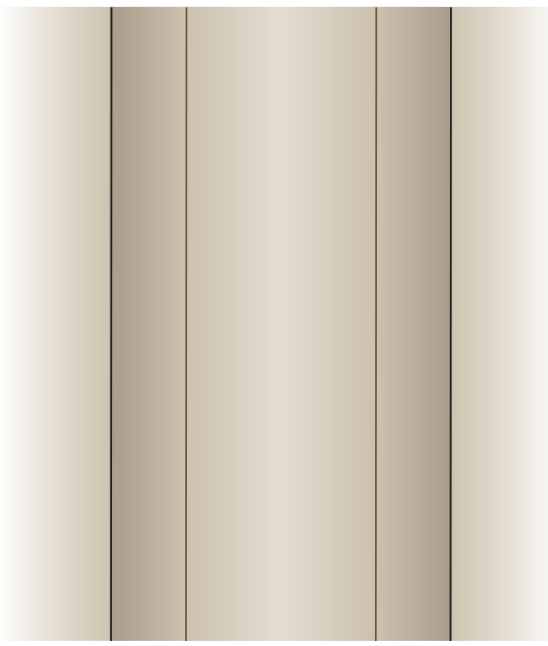

$B$. Vegetation conditions after 10 years

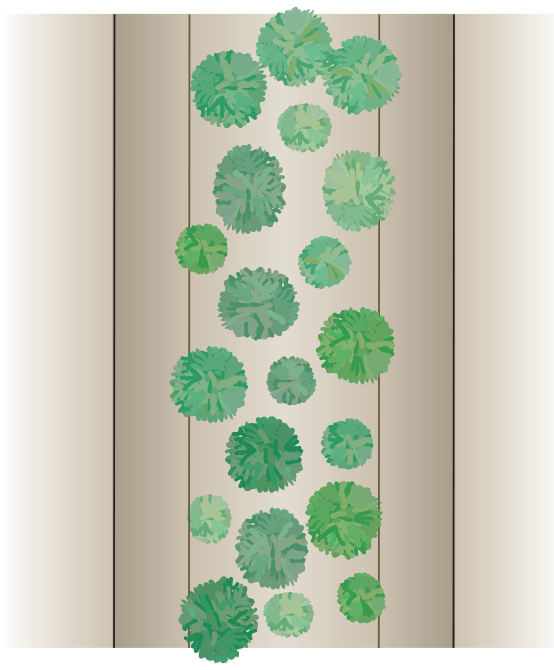

C. Vegetation following maintenance

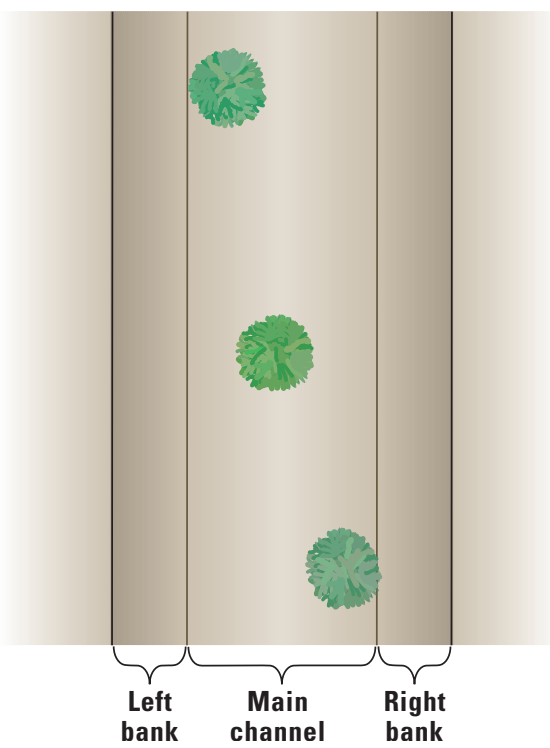

Figure 45. Plan view illustration of constructed channel for example case 2, scenario 1.
A. Before maintenance

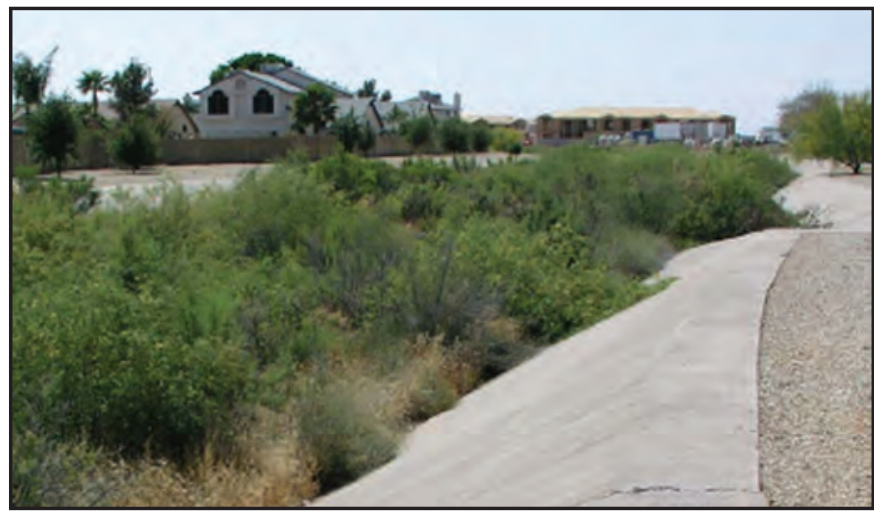

B. After maintenance

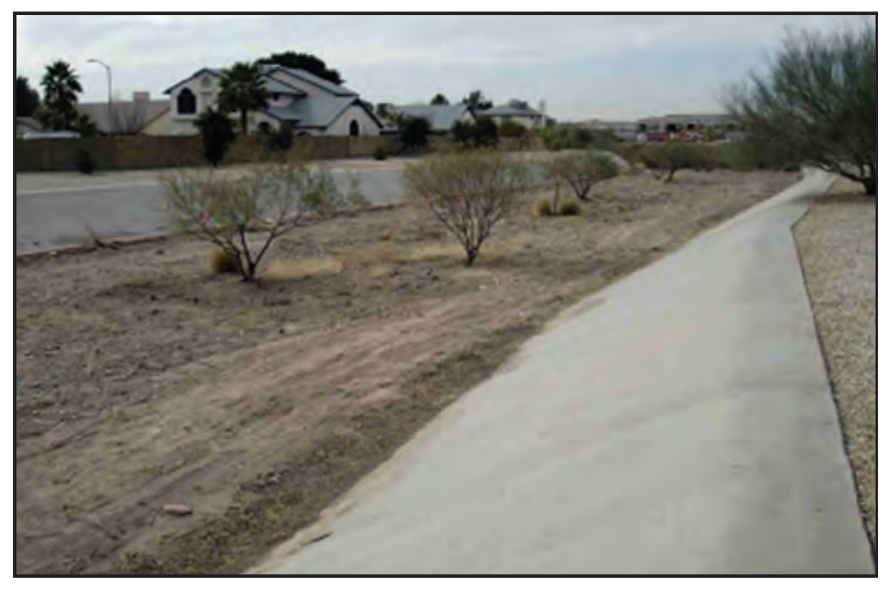

C. Approximately six months following maintenance

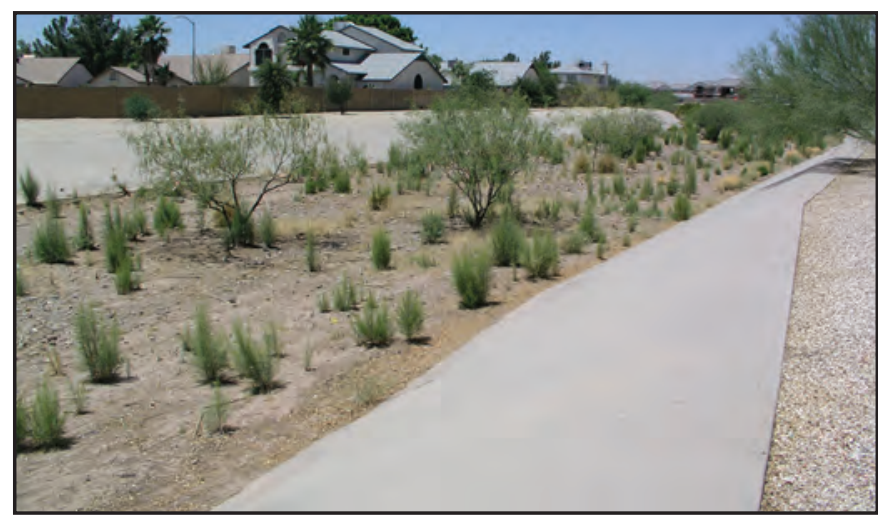

Figure 46. A constructed channel for example case 2, scenario 1. A, Manning's composite roughness coefficient is estimated to be 0.150 prior to vegetation maintenance. $B$, Energy loss components subsequent to vegetation maintenance. $C$, Vegetation conditions approximately six months following maintenance. 


\section{A. Originally designed channel}

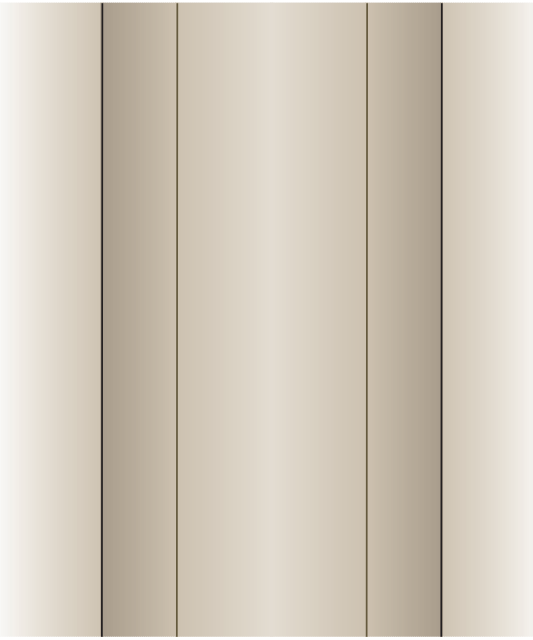

$B$. Vegetation conditions after 10 years

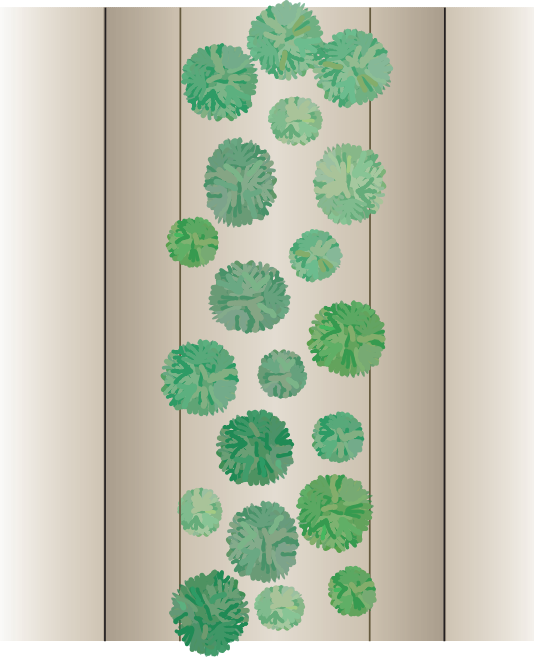

C. Vegetation following maintenance

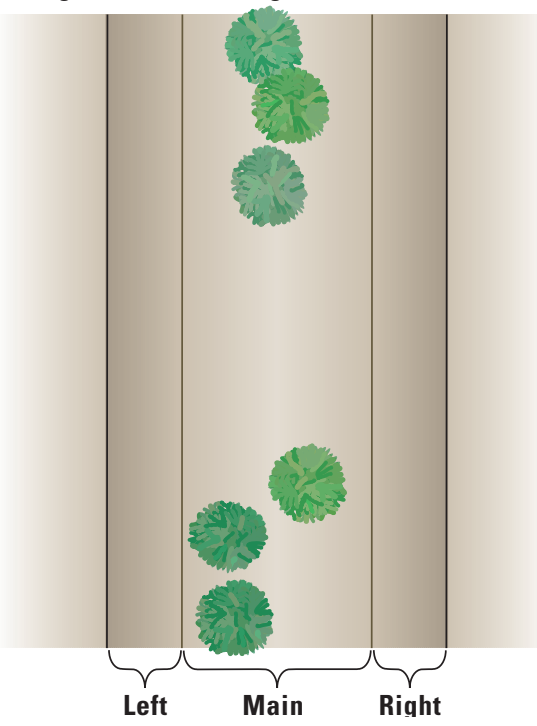

Figure 47. Plan view illustration of constructed channel for example case 2, scenario 2. Following vegetation maintenance, trees are clumped together primarily to provide better habitat for wildlife.

\section{A. Before maintenance}

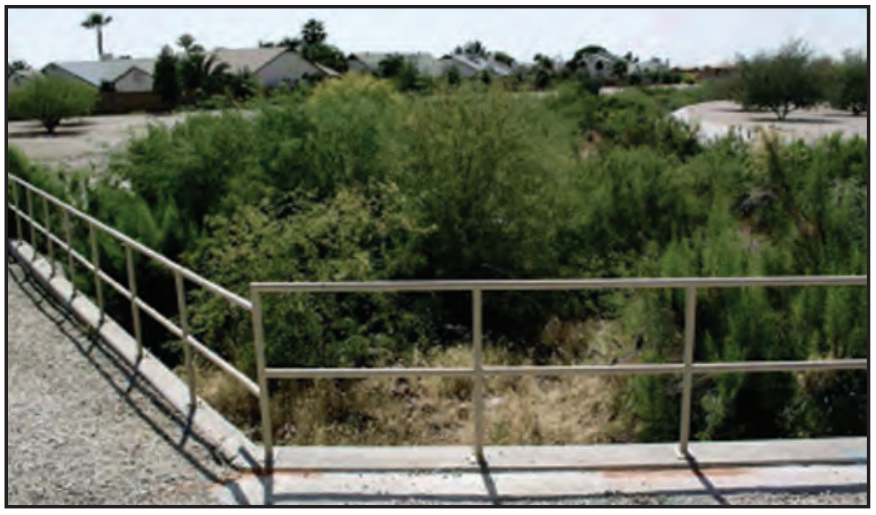

\section{$B$. After maintenance}

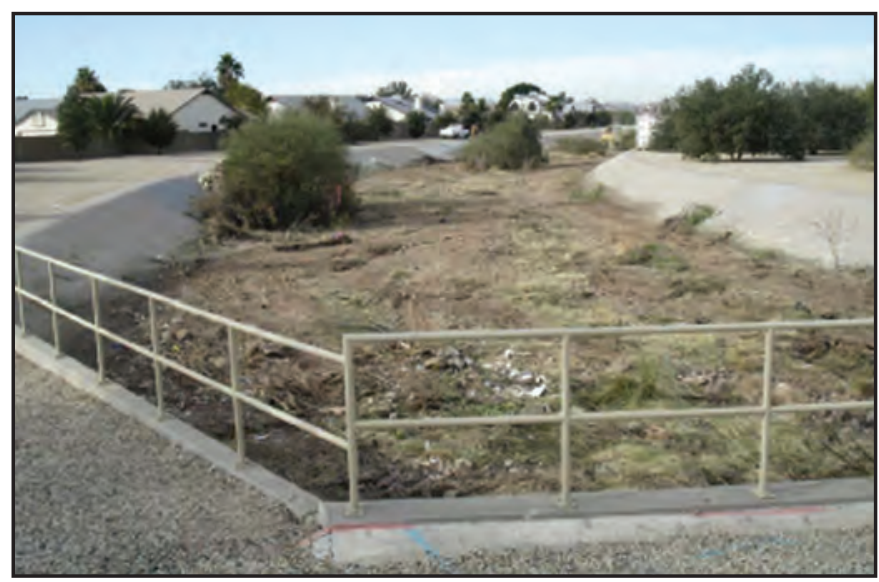

Figure 48. A constructed channel for example case 2, scenario 2. $A$, Manning's composite roughness coefficient is estimated to be 0.150 prior to vegetation maintenance. $B$, Manning's composite roughness coefficient is estimated to be 0.045 subsequent to vegetation maintenance.

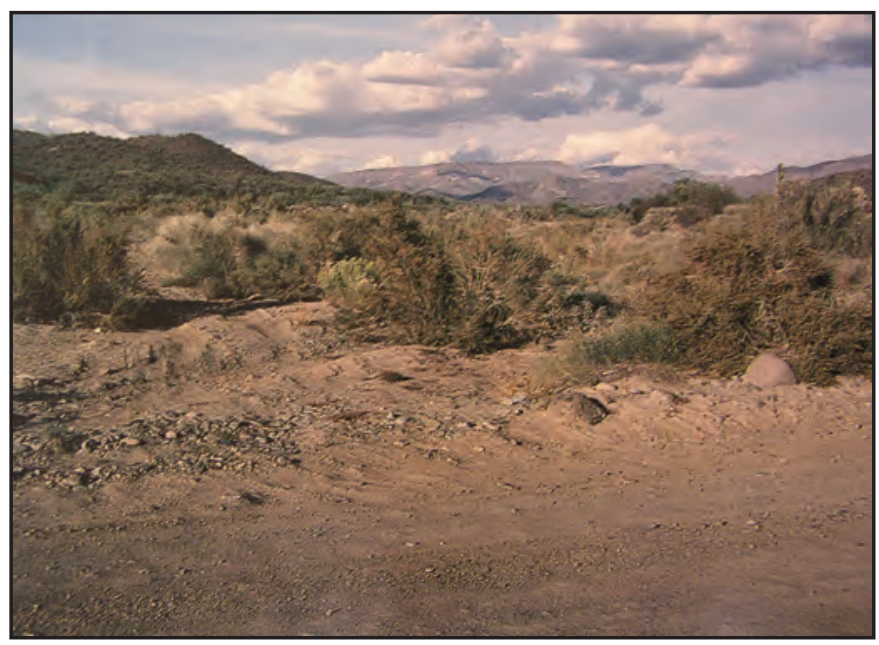

Figure 49. Example of a channel with randomly distributed shrubs prior to the statistical 25-year event. 


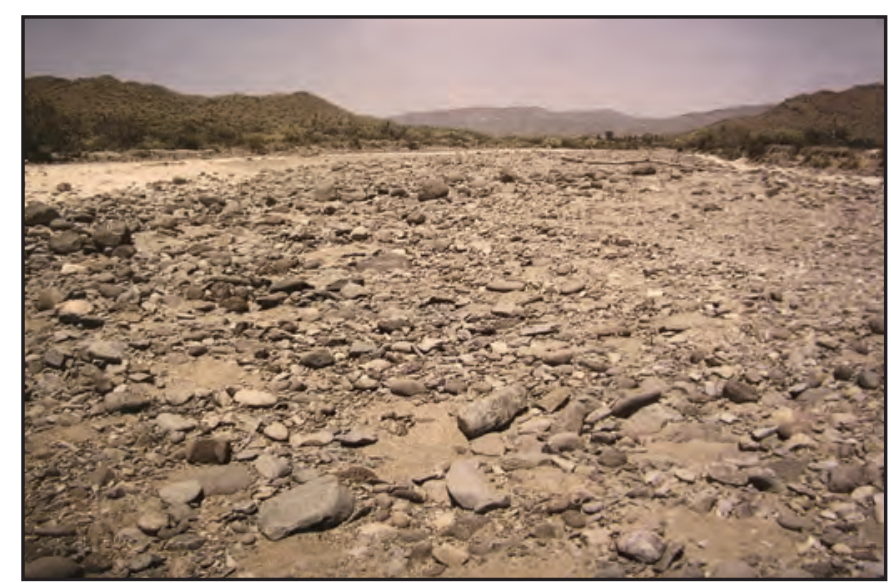

Figure 50. Example of a channel with removed shrubs following the statistical 25-year event.

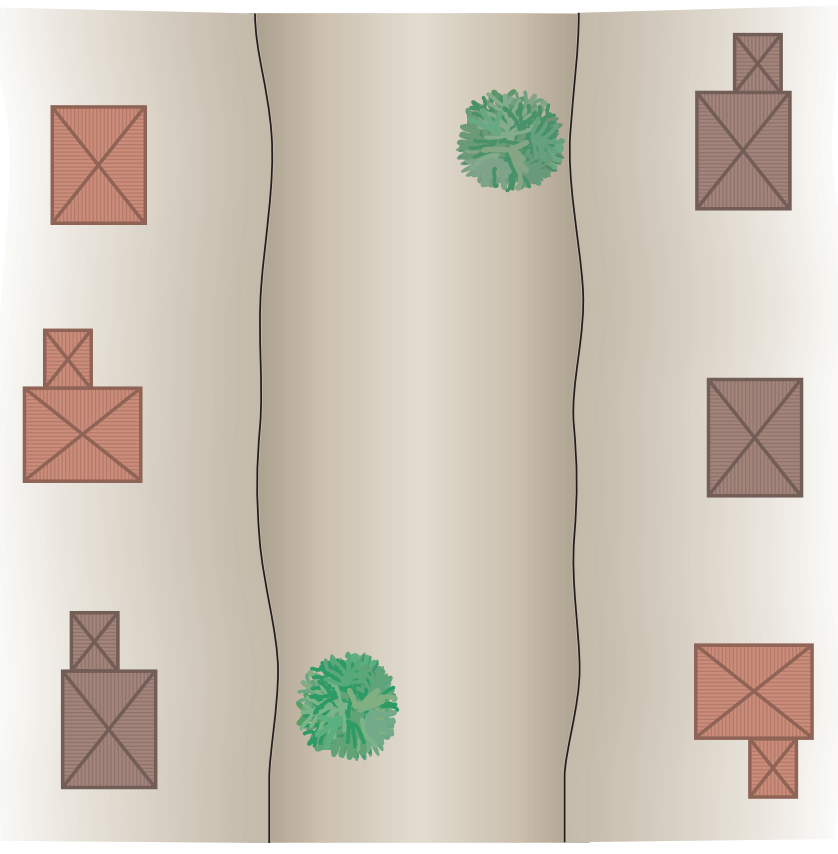

Figure 51. Locations and density of palo verde trees in the channel for example case 3 following the 25 -year flow event.
After 10 years the mesquite trees were mature, and the area maintained a density of approximately 6 to 7 mesquite trees per cross-section length of reach (fig. 56C). The mesquite trees averaged 16 feet in height. Homeowners generally were pleased with the aesthetic value of the dense and mature mesquite in the multiuse area, however, others, including the local flood-plain manager, were concerned that the design discharge would result in the loss of available freeboard and overtop channel banks. The new estimated composite roughness coefficient was in the range of 0.100 to 0.200 (table 3 ).

The stream-power relation was used to determine impact of the design discharge on the mesquite. For mesquite trees averaging 16 feet in height, the vegetation flexibility factor is $830 \mathrm{ft}-\mathrm{lbs}$. The amount of flow blocked by these trees is about 60 percent. Standard-step HECRAS computations were run for the channel with an $n$ value that averaged 0.150 . Velocity and hydraulic radius were acquired from these computations to determine the remaining vegetation-susceptibility index components (table 17). Values used for computation of stream power also were acquired from the standard-step computations (table 18). Stream power and the vegetation-susceptibility index were plotted for mesquite to determine if flow would have any impact on the vegetation (fig. 57).

The mesquite trees probably would not be altered by a 100-year design flow for this multiuse area (fig. 57). The design flow would, therefore, overtop the channel banks considerably (fig. 56C and $D$ ). A substantially larger flow would be required to alter the mesquite trees. In order to maintain the original BFE and 1-foot freeboard, all mesquite trees should be removed except those originally planted for which future growth was considered when $n$ values were selected for the original FIS (fig. $56 E$ and $F$ ). The vegetation assessment and maintenance plan should be followed closely to ensure that estimates of Manning's $n$ do not again exceed 0.077 .

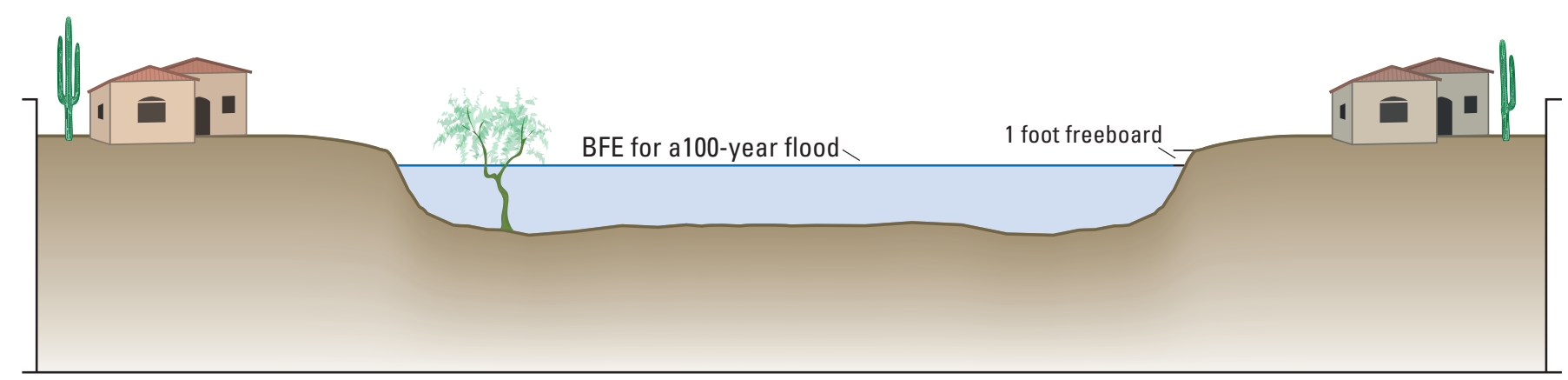

Figure 52. Base Flow Elevation (BFE) with 1 foot of freeboard for the channel used in example case 3 for a 100 -year design flood. 


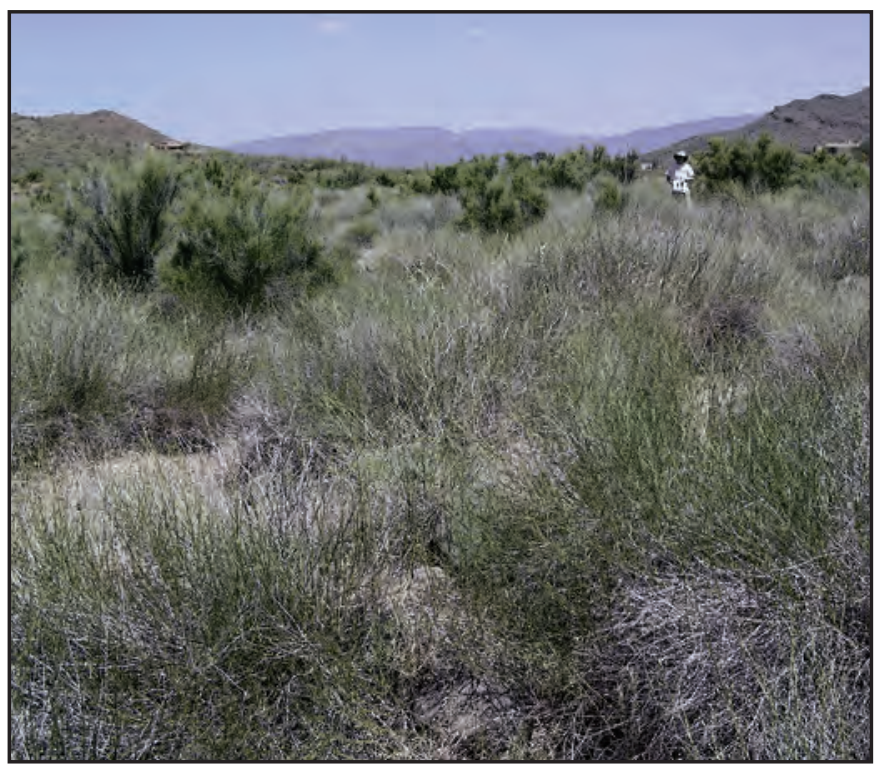

Figure 53. Example of a channel with a vegetation density greater than 70 percent, five years after a Flood Insurance Study.

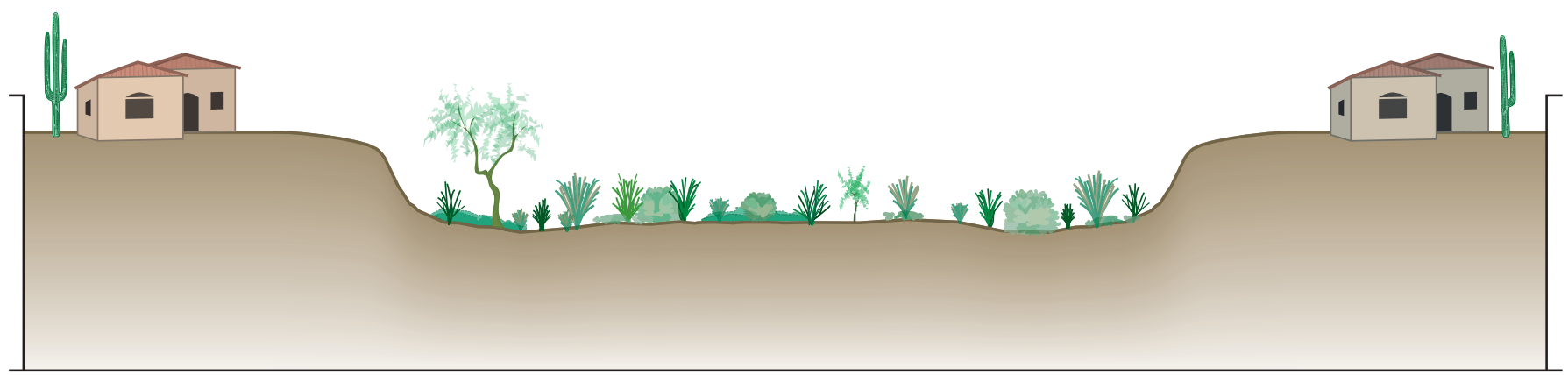

A. Cross-section view

B. Plan view

Figure 54. Example channel with development and five years of vegetation growth. $A$, Distribution of shrubs and trees in main channel and approximate location of homes. $B$, Shrubs (smaller circles) and palo verde (larger circles) and homes along channel.

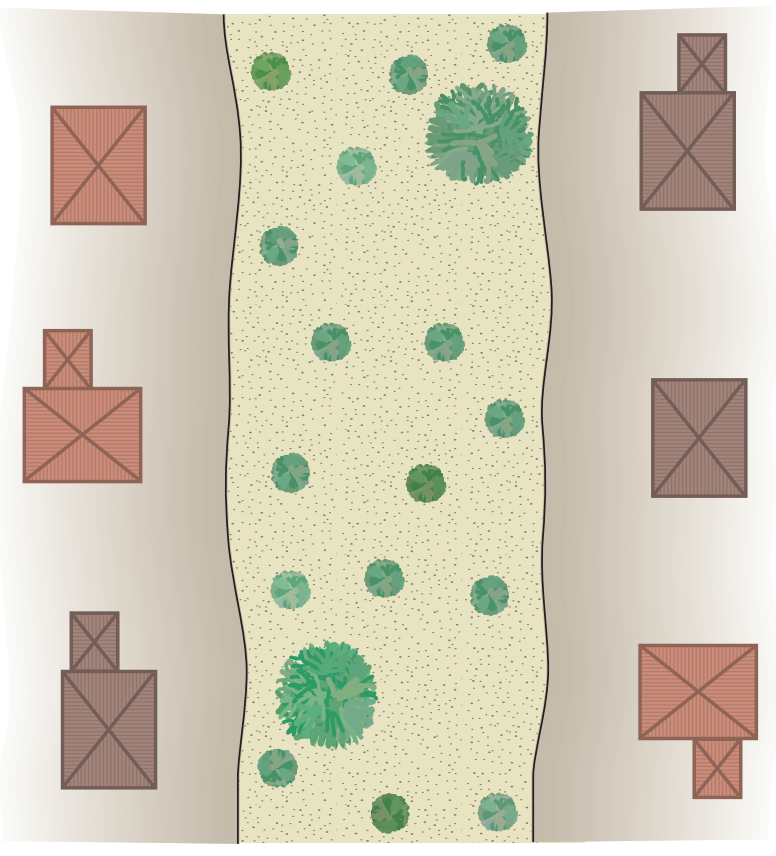


Table 15. Vegetation characteristics, coefficients, and vegetation-susceptibility index for shrubs and palo verde for example case 3.

$[\mathrm{ft}-\mathrm{lb}$, foot-pound]

\begin{tabular}{lcccccccc}
\hline & $\begin{array}{c}\text { Average } \\
\text { vegetation } \\
\text { height, } \\
\text { (feet) }\end{array}$ & $\begin{array}{c}\text { Vegetation- } \\
\text { flexibility } \\
\text { factor, } V_{\text {flex }} \\
\text { (ft-lb) }\end{array}$ & $\begin{array}{c}\text { Flow blocked } \\
\text { by vegetation } \\
\text { (percent) }\end{array}$ & $\begin{array}{c}\text { Vegetation- } \\
\text { blocking } \\
\text { coefficient, } \\
C_{\text {blocking }}\end{array}$ & $\begin{array}{c}\text { Vegetation } \\
\text { distributed } \\
\text { randomly or } \\
\text { parallel to } \\
\text { flow }\end{array}$ & $\begin{array}{c}\text { Vegetation- } \\
\text { distribution } \\
\text { coefficient, } \\
\boldsymbol{C}_{\text {dist }}\end{array}$ & $\begin{array}{c}\text { Ratio of hydrau- } \\
\text { lic radius to } \\
\text { average vegeta- } \\
\text { tion height }\end{array}$ & $\begin{array}{c}\text { Flow-depth } \\
\text { coefficient, } \\
C_{\text {depth }}\end{array}$ \\
\hline shrubs & 5 & 15.5 & $>70$ & 9 & Randomly & 1 & 0.7 \\
palo verde & 16 & 3,848 & $<30$ & 1 & Randomly & 1 & 5 \\
\hline
\end{tabular}

Vegetation-susceptibility index, $K_{v}=\left(V_{\text {flex }} C_{\text {blocking }} C_{\text {dist }} C_{\text {depth }}\right)=698 \mathrm{ft}-\mathrm{lb}$ (shrubs) and 231,000 ft-lb (palo verde)

Table 16. Hydraulic parameters used to compute stream power for example case 3.

$\left[\mathrm{ft}-\mathrm{lb} / \mathrm{s} / \mathrm{ft}^{2}\right.$, foot-pounds per second per square foot]

\begin{tabular}{cccc}
\hline $\begin{array}{c}\text { Specific weight of water, in } \\
\text { pounds per cubic foot }\end{array}$ & Hydraulic radius $(R)$, in feet & $\begin{array}{c}\text { Water-surface slope }\left(S_{w}\right) \text {, in feet } \\
\text { per foot }\end{array}$ & $\begin{array}{c}\text { Mean velocity }(U) \text { in feet per } \\
\text { second }\end{array}$ \\
\hline 62.4 & 3.6 & 0.009 & 10 \\
\hline & Stream Power, $\mathrm{SP}=62.4 R S_{w} V=20.2 \mathrm{ft}-\mathrm{lb} / \mathrm{s} / \mathrm{ft}^{2}$ & \\
\hline
\end{tabular}

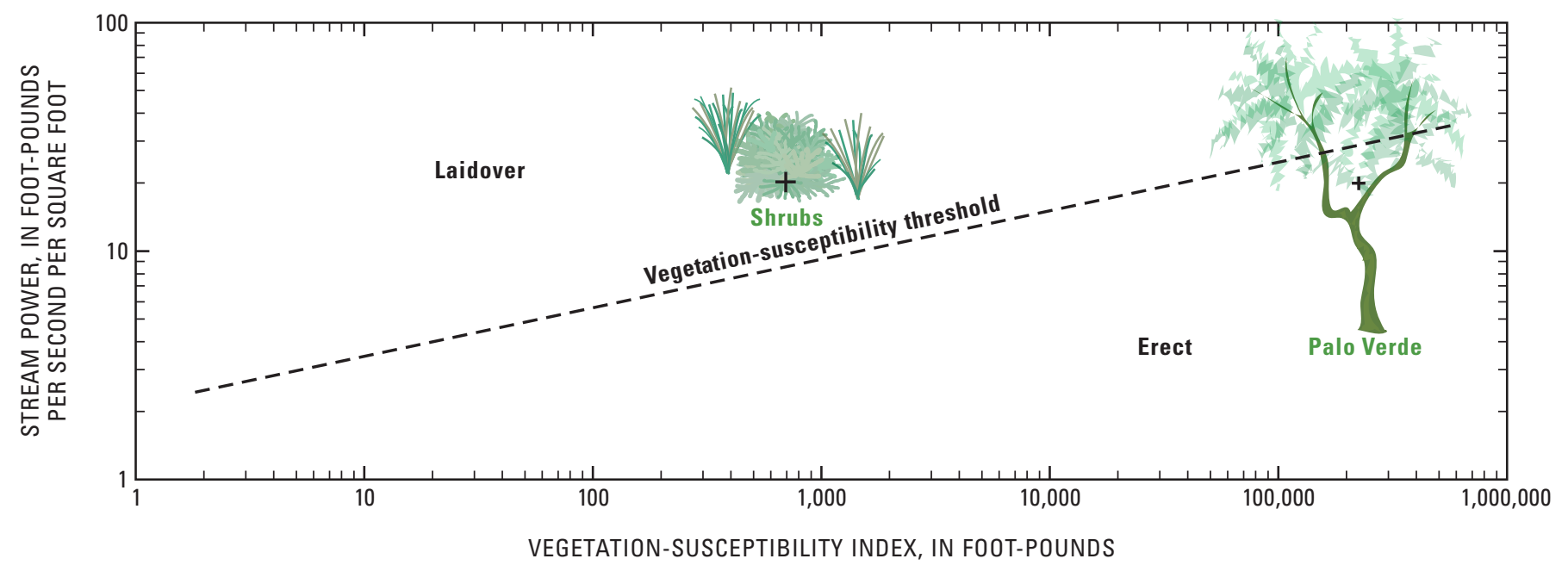

Figure 55. Impact of computed stream power on the vegetation-susceptibility index for shrubs and palo verde. 

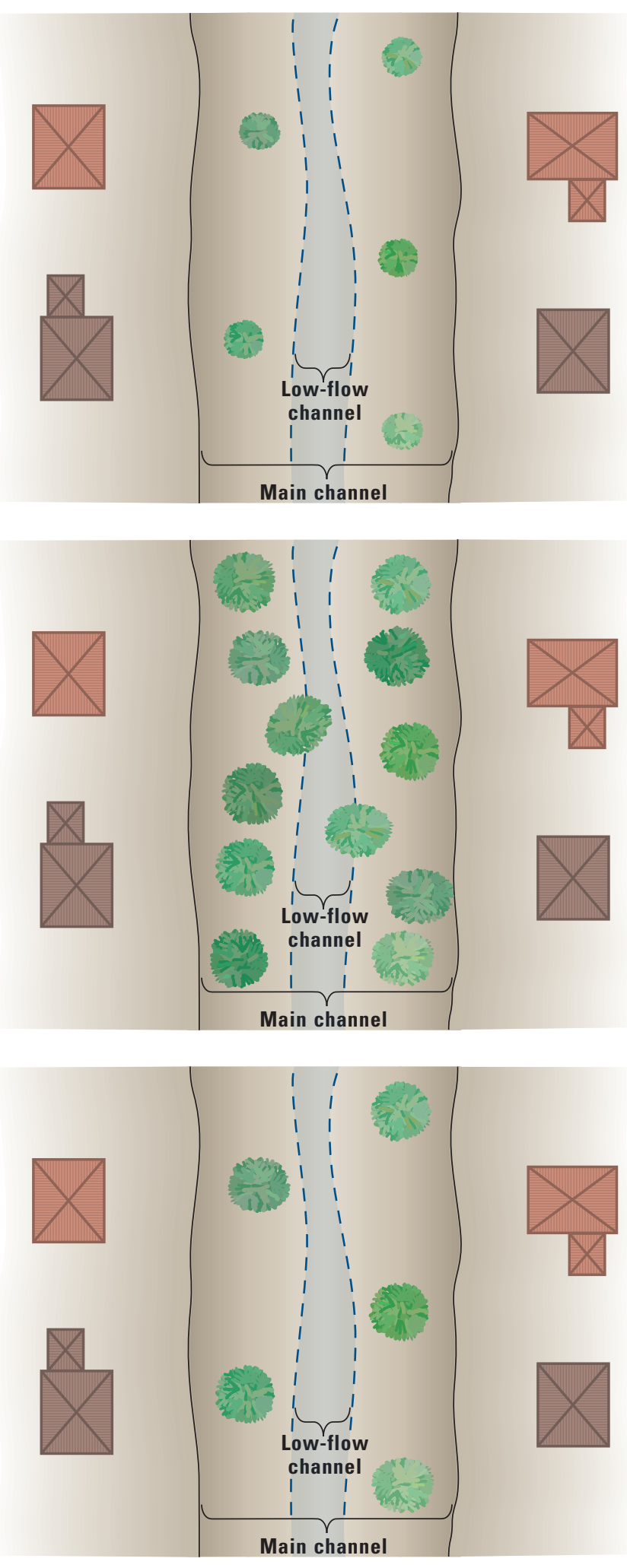

A. Plan view of initial planting

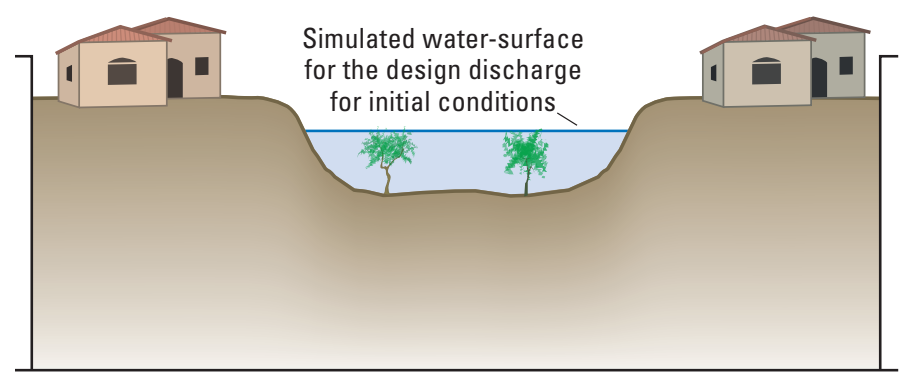

$B$. Cross-section view of initial conditions

C. Plan view after 10 years of growth

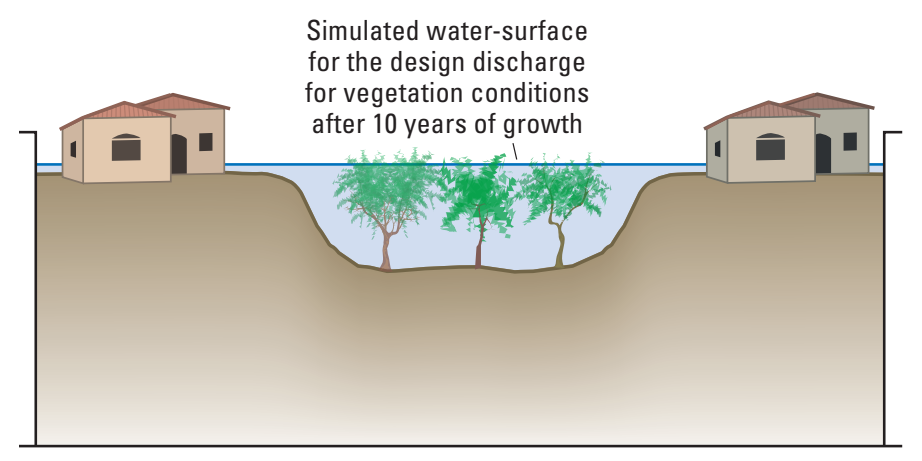

$D$. Cross-section view of vegetation conditions after 10 years of growth

E. Plan view of post-maintenance vegetation conditions

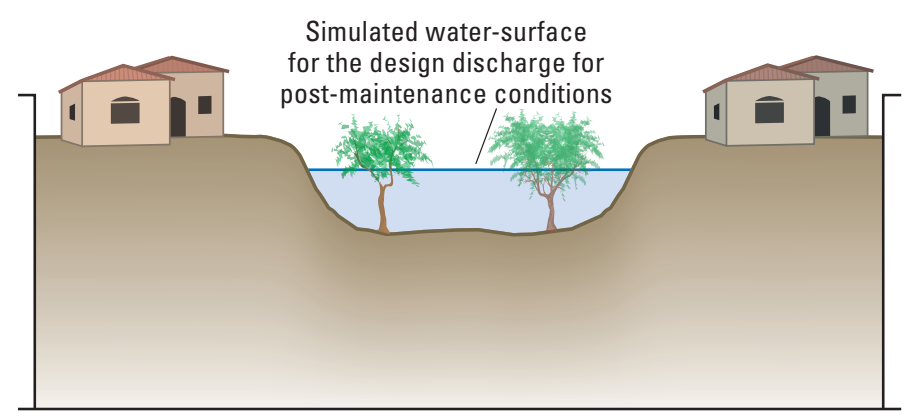

F. Cross-section view of post-maintenance conditions

Figure 56. Plan view and cross-section views showing distribution of mesquite in the main channel, as simulated water-surface elevation, and location of homes. $A$, Plan view after mesquite trees were initially planted. $B$, Cross-section view of simulated watersurface for the design discharge for initial conditions. $C$, Plan view showing mesquite trees after 10 years of growth. $D$, Cross-section view of simulated water-surface for the design discharge for vegetation conditions after 10 years of growth. $E$, Plan view showing remaining mesquite trees following vegetation maintenance. $F$, Cross-section view of simulated water-surface for the design discharge for post-maintenance conditions. 
Table 17. Vegetation characteristics, coefficients, and vegetation-susceptibility index for mesquite for example case 4.

\begin{tabular}{|c|c|c|c|c|c|c|c|c|}
\hline $\begin{array}{c}\text { Vegetation } \\
\text { type }\end{array}$ & $\begin{array}{c}\text { Average } \\
\text { vegetation } \\
\text { height, (feet) }\end{array}$ & $\begin{array}{l}\text { Vegetation- } \\
\text { flexibility } \\
\text { factor, } V_{\text {flex }} \\
\text { (ft-lb) }\end{array}$ & $\begin{array}{l}\text { Flow blocked } \\
\text { by vegetation } \\
\text { (percent) }\end{array}$ & $\begin{array}{c}\text { Vegetation- } \\
\text { blocking } \\
\text { coefficient, } \\
C_{\text {blocking }} \\
\end{array}$ & $\begin{array}{c}\text { Vegetation } \\
\text { distributed } \\
\text { randomly or } \\
\text { parallel to flow }\end{array}$ & $\begin{array}{c}\text { Vegetation- } \\
\text { distribution } \\
\text { coefficient, } \\
C_{d i s t} \\
\end{array}$ & $\begin{array}{c}\text { Ratio of hydrau- } \\
\text { lic radius to av- } \\
\text { erage vegetation } \\
\text { height }\end{array}$ & $\begin{array}{c}\text { Flow-depth } \\
\text { coefficient, } \\
C_{\text {depth }}\end{array}$ \\
\hline mesquite & 16 & 830 & 60 & 4 & Randomly & 1 & 0.6 & 20 \\
\hline \multicolumn{9}{|c|}{ Vegetation-susceptibility index, $K_{v}=V_{\text {flex }} C_{\text {blocking }} C_{\text {dist }} C_{\text {depth }}=64,400 \mathrm{ft}-\mathrm{lb}$} \\
\hline
\end{tabular}

Table 18. Hydraulic parameters used to compute stream power for example case 4.

[ft-lb/s/ft ${ }^{2}$, foot-pounds per second per square foot]

\begin{tabular}{cccc}
\hline $\begin{array}{c}\text { Specific weight of water, in } \\
\text { pounds per cubic foot }\end{array}$ & Hydraulic radius $(R)$, in feet & $\begin{array}{c}\text { Water-surface slope }\left(S_{w}\right) \text {, in feet } \\
\text { per foot }\end{array}$ & $\begin{array}{c}\text { Mean velocity }\left(h_{\text {, in feet per }}\right. \\
\text { second }\end{array}$ \\
\hline 62.4 & 9 & 0.003 & 5 \\
\hline & Stream Power, $\mathrm{SP}=62.4 R S_{w} V=8.42(\mathrm{ft}-\mathrm{lb} / \mathrm{s}) / \mathrm{ft}^{2}$ \\
\hline
\end{tabular}

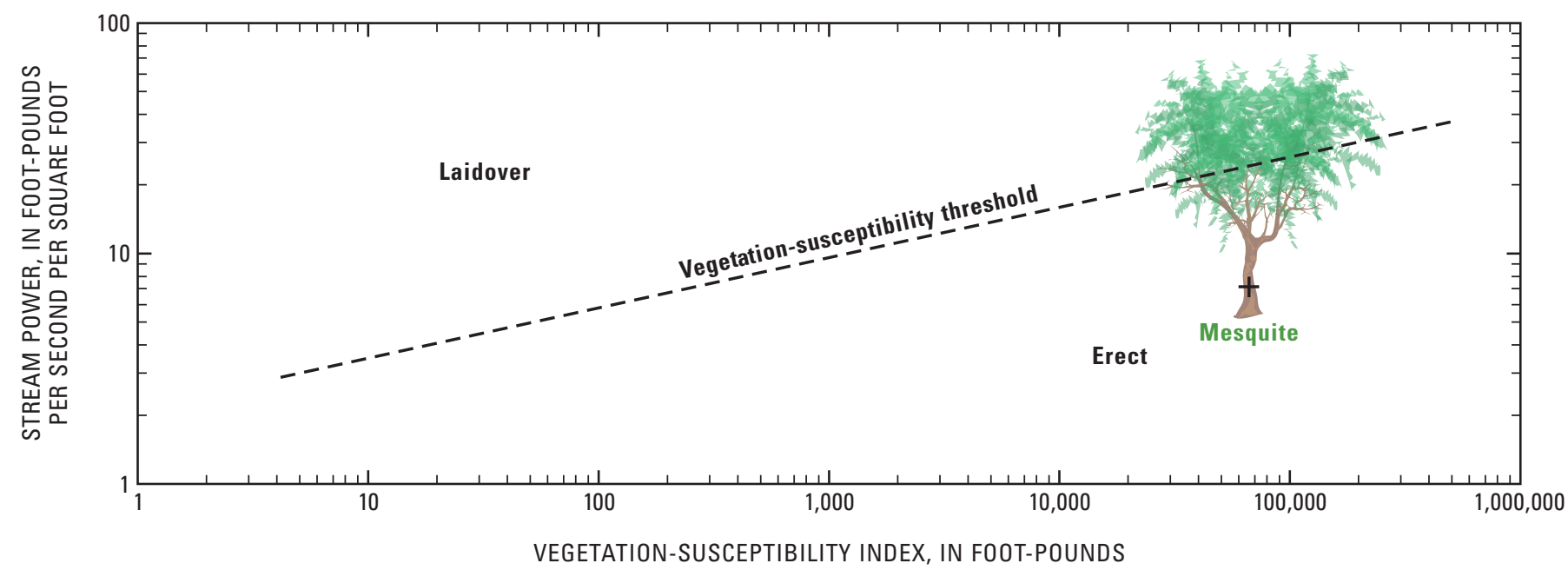

Figure 57. Impact of computed stream power on the vegetation-susceptibility index for mesquite trees. 


\section{SUMMARY AND CONCLUSIONS}

Hydraulic computations of open-channel flow require evaluation of the channel's resistance to flow, which typically is represented by a roughness parameter. The Manning's roughness coefficient, $n$, commonly is used to represent flow resistance. Verified and estimated Manning's roughness coefficients for natural and constructed stream channels in Arizona have been presented in several previously published documents. Most of the information from which is available in the form of guidelines, tables, figures, and examples.

Proper estimation of $n$ values for open channels in arid to semi-arid environments can present difficulties in estimating channel resistance. In particular, vegetation in ephemeral and intermittent streams can be a constantly changing factor making estimation of $n$ for this energy-loss component difficult. Vegetation can grow to large proportions in just a few seasons, and floods may dramatically alter the roughness characteristics of the channel by flattening or even removing vegetation, which acts to decrease Manning's $n$. Roughness coefficients selected in hydraulic studies years or decades earlier may change significantly. Consequently, earlier computed water-surface elevations may no longer be valid for the design discharge. Semi-empirical relations and guidelines developed to estimate the impact of flow on channel vegetation conditions and the resultant impact on Manning's $n$ are presented in this document.

In the past, heavy growths of vegetation, which were believed to substantially increase Manning's $n$ value and decrease channel conveyance, commonly were removed completely to enable adequate conveyance of floodflows. In recent decades, however, emphasis has shifted toward preservation of riparian vegetation to provide habitat for many species of wildlife, as well as aesthetically pleasing multiuse areas for homeowners and businesses. Developed and presented herein are engineering-based guidelines for optimizing the preservation of riparian habitat and the aesthetics of multiuse areas, while mitigating damage from floodflows along stream channels. The guidelines primarily are based on the vegetation component of Manning's $n$ that should be maintained in a waterway to allow adequate freeboard, which is an additional amount of conveyance area intended to mitigate risk by providing a factor of safety.

The information, methods, and guidelines available in this report are presented to provide a tool for engineers, hydrologists, developers, and conservationists to gain experience and make better and informed decisions when selecting values of Manning's $n$ based on channel and vegetation conditions.

\section{Acknowledgments}

T.R. Loomis, T.M. Pinto, D. Stuart, C. Klenner, and R. Miracle, Flood Control District of Maricopa County; and B.N. Aldridge, J.M. Garrett, B.W. Thomsen, H.W. Hjalmarson, S.M. Wiele, and K.M. Nolan, U.S. Geological Survey, contributed significantly to the technical substance of this report. 


\section{REFERENCES}

Aldridge, B.N., and Garrett, J.M., 1973, Roughness coefficients for stream channels in Arizona, U.S. Geological Survey Open-File Report, 87 p.

Barnes, H.H., Jr., 1967, Roughness characteristics of natural channels: U.S. Geological Survey Water-Supply Paper $1849,213 \mathrm{p}$.

Benson, M.A., and Dalrymple, T., 1967, General field and office procedures for indirect discharge measurements: U.S. Geological Survey Techniques of Water-Resources Investigations, book 3, chap. A1, $30 \mathrm{p}$.

Burkham, D.E., 1976, Hydraulic effects in bottom-land vegetation on three major floods, Gila River in southeastern Arizona: U.S. Geological Survey Professional Paper 655-J, p. 14.

Chow, V.T., 1959, Open-channel hydraulics: New York, McGraw-Hill, 680 p.

Cowen, W.L., 1956, Estimating hydraulic roughness coefficients: Agricultural Engineering, v. 37, no. 7, p. 473-475

Cruff, R.W., 1999, Channel subdivision and bank selection in open channels; Phoenix, Arizona. Flood Control District of Maricopa County engineering library, $17 \mathrm{p}$.

Davidian, Jacob, 1984, Computation of water-surface profiles in open channels: U.S. Geological Survey Techniques of Water Resources Investigations, book 3, chap. A15, 48 p.

Fischenich, C., 2000, Resistance due to vegetation, EMRRP Technical Notes Collection, U.S. Army Engineer Research and Development Center, Vicksburg, MS.

Jarrett, R.D., 1985, Determination of roughness coefficients for streams in Colorado, U.S. Geological Survey WaterResources Investigations Report 85-4004.

Karim, F., 1995, Bed configuration and hydraulic resistance in alluvial-channel flows: Journal of Hydraulic Engineering, v. 121 , no. 1 , p. 15-25.

Leopold, L.B., Wolman, M.G., and Miller, J.P., 1964, Fluvial processes in geomorphology: New York, Dover Books on Earth Sciences, 503 p.

Limerinos, J.T., 1970, Determination of Manning's coefficient from measured bed roughness in natural channels: U.S. Geological Survey Water-Supply Paper 1898-B, 47 p.

Phillips, J.V., McDoniel, D., Capesius, J.P., and Asquith, W., 1998, Method to estimate effects of flow-induced vegetation changes on channel conveyances of streams in Central Arizona, U.S. Geological Survey Water-Resources Investigations Report 98-4040, 43 p.
Phillips, J.V., and Hjalmarson, H.W., 1994, Floodflow effects on riparian vegetation in Arizona: New York, American Society of Civil Engineers Proceedings of the 1994 National Conference on Hydraulic Engineering, v. 1, p. 707-711.

Phillips, J.V., and Ingersoll, T.L., 1998, Verification of roughness coefficients for selected and natural channels in Arizona: U.S. Geological Survey Professional Paper 1584, $77 \mathrm{p}$.

Riggs, H.C., 1976, A simplified slope-area method for estimating flood discharges in natural channels: U.S. Geological Survey Journal of Research, v. 4, no. 3, May-June 1976, p. 285-291.

Simons, D.B., and Richardson, E.V., 1966, Resistance to flow in alluvial channels: U.S. Geological Survey Professional Paper 422-J, $61 \mathrm{p}$.

Thomsen, B.W., and Hjalmarson, H.W., 1991, Estimated Manning's roughness coefficients for stream channels and flood plains in Maricopa County, Arizona: Phoenix, Arizona, Flood Control District of Maricopa County, 126 p.

Webb, R.H., and Betancourt, J.L., 1992, Climatic variability and flood frequency of the Santa Cruz River, Pima County, Arizona: U.S. Geological Survey Water-Supply Paper 2379, $40 \mathrm{p}$. 


\section{APPENDIX}

\section{Vegetation Assessment and Maintenance Plan}

1. Site.

2. Date.

3a. Initial visit. _ ( $(\mathrm{y} / \mathrm{n})$. 3b. If no, visit number.

4. Photograph (if available) and plan view sketch of initial conditions.

5. Photograph and plan view sketch of current conditions.

6. Initial Manning's $n$ value used to delineate design-flow elevations.

7. Current estimated Manning's $n$ value.

8. Survey or observe channel substrate. If aggradation or degradation has occurred in the reach, a new survey of cross sections may be necessary.

9. After assessment with stream power relations, are current Manning's $n$ values outside the target range? $(y / n)$

10. If yes, describe plan to bring Manning's $n$ values back to original $n$ value. If no, briefly describe rationale for the decision and recommendations for future years.

11. Sketch (plan view) of vegetation maintenance plan (if necessary, flag trees and brush to be removed and trees that require trimming).

12. Photograph and sketch (plan view) of channel and vegetation conditions following maintenance. 